\title{
Embodying the Creative Spirit
}

Haley Dee Tynes

Little Rock, Arkansas

Bachelor of Science, University of Central Virginia, 2013

A Thesis presented to the Graduate Faculty of The University of Virginia in Candidacy for the Degree of Master of Fine Arts

Department of Drama

University of Virginia

May, 2017 
$\underline{\text { Table of Contents }}$

Title Page

Table of Contents $\quad$ i

Introduction $\quad$ ii

Chapter $1+1$

$\begin{array}{ll}\text { Chapter } 2 & 27\end{array}$

Chapter $3 \quad 53$

$\begin{array}{ll}\text { Conclusion } & 65\end{array}$

$\begin{array}{ll}\text { Appendix Table of Contents } & 67\end{array}$

$\begin{array}{ll}\text { Appendix introduction } & 74\end{array}$

$\begin{array}{ll}\text { Appendix Chapter } 1 & 77\end{array}$

Appendix Chapter $2 \quad 96$

$\begin{array}{ll}\text { Appendix Chapter } 3 & 112\end{array}$

$\begin{array}{ll}\text { Appendix Conclusion } & 121\end{array}$

$\begin{array}{ll}\text { Bibliography } & 122\end{array}$ 


\section{$\underline{\text { Introduction }}$}

In order to describe the evolution of my creative process, I reflect back on one of my favorite assignments in my first year of graduate school. The assignment asked me to select an image of a period garment of my choice translate it into four different drawings. I focus my project on an ensemble from the Kyoto Institute Collection, a collection that recognizes the evolution of women's fashions from the $18^{\text {th }}$ to the $20^{\text {th }}$ century (Kyoto, $p$. 101). I chose a Late Georgian red and white jacket with a beige colored skirt, the edges embroidered with flowers. The first three drawings I produced guided me to create three different interpretations of the dress.

The first part of the project asked me to create a 2 dimensional reality into a drawing and painted sketch. Painting the garment allowed me to concentrate on the details, trying to make my painted sketch resemble the picture of the dress. (Figure I.1) The second part of the project had me selecting a fashion plate from circa 1780s. I recreated the fashion plate, this time I paint in the Kyoto dress onto the illustrated woman (Figure I.2). The third part of the project resembled the second. Instead of a fashion plate, I took on a painting by Thomas Gainsborough circa 1770s. This project required me to learn the technique of the painter while still trying to create the dress (Figure I.3). The fourth and last installment of the project asked for me to create a deconstructed image of the ensemble. Instead of an interpretation from different images, this assignment asked me to create something that connected to myself. 
Confused as to how to do this, I scramble to come up with ideas. I hold a pencil tightly in my hand, lead hovering over my paper. I stare at the barren white paper, my mind blank. Nothing comes. I see my peers move about the room, sketching and writing as my pencil still hovers above the blank canvas. In a fit of aggravation, I snatch up the paper and crumble it into my palm. Then, I mash the paper into a tight ball. The feeling satisfies something inside me. I rip another sheet out of my binder and repeat the action. I place the two together. I proceed with a third sheet, this one containing doodles and notes from a previous class. I add it to the pile.

The crushed up paper becomes the study with the result inspiring an idea that took form in my mind. With each action of crumbling and adding this paper changes the pile. Suddenly texture brings meaning to the space. Though the page contains crushed scribbles, they contain my lines. A part of me joins the crumbled piece in the pile of scraps.

An idea comes. What if these doodles, these words, could create the dress? I could construct the image with scraps of failed sketches, drafts of paperwork, and unrealized concepts creating the original silhouette through a collage. The moment pushes me to explore more, spending a weekend ripping up old works I thought useless. A flurry of layering, rearranging of torn paper, and painting causes me to stop and look at the work. I find myself expressed in the chaos of the mashed papers. (Figure I.4) I observe that this project symbolizes the release of my new found creativity, and my readiness to embrace an unearthed part of me. While experiencing the assignment, the concepts and ideas that come to me feel like sparks of inspiration that burn through my 
mind and spark down to my fingertips, my body acting before my mind can form a realized solution.

During my time in graduate school my advisor introduced me to Betty Edward's book, Drawing on the Right Side of the Brain. Edward's writing taught me how to understand these creative sparks by using the Getzels model to help articulate the stages of creativity: first insight, saturation, incubation, illumination - the Ah-ha! moment, and verification. Now, as a third year graduate student, I can use these stages to plot out my creative process step by step.

The first stage of the model, the first sight, is that moment when ideas are spark and start to form. This pushes in to the second stage, saturation, which in reference to the creative process detailed above, came in the form of crushing paper into tight balls. Once the balls began to shape into something, I moved past saturation and into incubation. Moving back and forth between saturation and incubation I eventually saw the solution, the ah-ha, appear before me. After this illumination, I moved back into the energy of saturation and incubation as I combined my old works together. The completion of the project directed me to the final stage of the process, verification, where I determined that I successfully reached my personal goals and succeeded in creating the assigned deconstruction of this garment.

As I review my work over the past three years, I discover the power of the Getzels model as it supports the articulation of my creative process. I discover that my personal creative process guides my private discipline and my collaboration with directors and 
designers, technologists and actors. Through investigations into my design process, I breakdown my work and reflect on how I go through each experience. Each play I encounter builds upon my creative process of past productions, revealing my skills and defining my mastery of costume design and technology. 


\section{Chapter One}

I begin each production I design by studying the play. Breaking down the play with research into the special world and character, I gather information that will help me better understand what the playwright attempts to invoke in me and the audience. I call this process my priviate discipline. This preperation guides my overall design of the play, helping me answer questions and find solutions to the actions of the characters, and how their world affects them. Without immersing myself in this first step, I would be unable to articulate the play to the director and my fellow design team. Before coming to the University of Virginia, my personal preperation before going into collaborations with the director and other designers included reading the play, gathering research, and creating the sketches. Though these remain the ultimate goals for every project, I realize how little I understood of the play as an undergraduate compared to how I now fully analyze the play.

As an undergraduate designer, I began by first reading the script for pleasure. Reading the play numerous times allowed me to gather new information each time. I monitored my reaction to the story, gathering seeds from which ideas and decisions would grow. Once I completed the story, I asked questions of my own emotional response to the piece. What was my reaction to the play? What emotions did it evoke? Why is this important?

With design meetings beginning a few days into my fall term, my undergraduate process would serve me as I prepared for my first UVA drama design, The Rimers of 
Eldritch by Landford Wilson (Figure 1.1). Before design classes began I jumped into the world of a small midwestern town of Eldritch and the townspeople. The playwright tells the story of a town locked in a trial seeking to discover who murdered the town drunk, Skelly. This storytelling plays out through vignettes of the townspeople revealing their relationships, attitudes, and intelligence. We watch as an older woman falls for a young stranger, a disabled girl loses herself in her daydreams while her mother mourns the burden of caring for her disabled child. We encounter a lonely boy who resides in the shadow of his dead brother, a coarse woman who abuses her aging mother, teenagers struggling to discover their place in the world, and parents distanced from their children and themselves.

The playwright tells the story through scenes spanning from fall to spring, delving deeper into the world of Bible Belt America and its tendency for violence and false morality. By the end of the story, we leave with a different impression of the townspeople than when we came. The community of support proves false revealing callous gossip, compassionless religion, sex hungry teens, selfish women and silent men.

When I first read the play, I feel a sense of emptiness. The town builds itself on Christian values and civic duty towards their fellow man. The members of the town conceal the darkness in their hearts, letting their unhappiness seep out through cruel words toward family members and the outcasts in the town. I recognize this town. I spent most of my childhood in the small town of Shirley, Arkansas. It sits atop of a mountain, close to the Buffalo River with a population of 200 people. I graduated from Shirley High School with 32 other students. The citizens who live in the town have 
nothing better to do but gossip about one another. If two people dislike each another, the conflict leeches to friends and neighbors much like the Hatfields and McCoys. The poorer students in high school make the "troublemaker" list while the students with more money tend to be arrogant and distruptive.

I find myself a part of Eldritch as I read through the play. The scenario, the characters, and the world they create feel like a stolen memory. With that thought, I read through the play for the second time. I reflect on my creative process. With the first insight of the Getzels model, the first reading connects to the beginning of understanding the script. The spark of the idea allows me to embrace my emotional response to the play. It lets me to take a more strategic approach. In this read through I look for the concept of the story. What is the main idea of the story? What does the author want the audience to understand and feel when they walk away from this performance?

Eldritch epitomizes a broken community of the mid 50s midwest. These characters live under the pretense that the town and the people in it support each other. Residing in a small town, they know their neighbors, their family, and all of the trials they have been through. But knowing everything about the people living next door will not make a community. Their lack of unity and support creates this break. The people of Eldritch know each other's dirty secrets, but they do not know how to care for each other nor do they desire to. The play is set in the period of the late 60s. In this decade, the prospect of 'the cookie cutter family' holds firm yet the people of Eldritch seem to share few family values. For example, Eva, the disabled girl, lives with her mother, Evelyn, 
who continuously asks God what she has done to receive such a burden as her daughter. During a scene in act two, Eva breaks down screaming in the courtroom.

Instead of consoling her daughter, Evelyn blames God before the rest of the town. "See her crippled body. See her broken back; why, why has God crushed me with sucha burden. I don't complain. I ask why? We love him. We Bless him. We praise him....Why? I said, Why! I have the right to know; I'll repent if I've done anything; If I've sinned." (Rimers, p.43). A broken mother, Evelyn proves in previous scenes that she sees her daughter as a punishment from God. We know Families should support one another, yet Evelyn resents her daughter. None comes to her rescue or believes she wants to be rescued. The townspeople suffocate one another, breeding negativity.

The two read-throughs and applied thinking drive my decisions throughout the design process as I move on to the next phase of the Getzel model, saturation. This leads me to images of small community gatherings and broken families in the 1960s. From there, I scramble to gather pictures that echo the dress of a small town. I focus on photographs of family portaits, a congregation of a small town church, and pictures of friends. I find myself drawn to pictures that depect old, weathered houses lost to nature, open spaces that seem to lead to nowhere, and images that invoke a sense of entrapement. With these photos I sketch the world of Eldtrich (Figure 1.2).

Though the overall design of The Rimers of Eldrich proved sucessful, I think back to my decision-making process and wonder what the show would reflect if I were to design it now and how I might approach it. I look to my photographs of the show and see 
different silouhettes and profiles, a sense of unity tied together by the lines of the garments and the colors of the clothes. However, I believe a full analysis of the play would have guided me to some of the same profiles of the characters, but would have strengthen weaker ones. As my graduate studies grow, I learn how to really dive into the script, breaking down the reading to help strength my design choices.

Following my design of Landford Wilson's The Rimers of Eldritch in the fall, I plunge into my first design class and a stricter private discipline in the spring semester, where my paper project designs help to create a new foundation. This new process supports the cultivation of my artist's eye, as well as broadens my creative spirit. Each different project teaches me how to view details in the script that can shape the physical, emotional, and psychological world that the playwright captures. I view these projects as stepping stones prior to designing my next realized production. The unrealized projects sharpen my private discipline, exposing me to a variety of playwrights, theatre styles, and cultural periods. They sculpt the way I understand plays, teaching me how to capture my vision and connecting me with the cultural period and its clothing as I move me ideas out into performance before an audience.

This first semester we learned that one of our most valuable tools of collaboration would become the Hodge analysis. Director and professor, Francis Hodge created this detailed breakdown of the script based on Aristotle's Poetics for directors, designers, and actors alike. The seven parts include: given circumstances, dialogue, dramatic action, character, idea, tempos, and moods. Breaking down each section helps with the 
discussion of the play, yet each part builds onto one another. Some do not take shape until answering the previous section.

1.) The given circumstances guide me into the given facts of this special world, asking me to first look into the environmental facts of the play. I list the geographical location, the date with the season and time of day. I include the economic, political, social and religious environments of the special world. I also record each character's previous actions, helping me to create the back stories. This supports the actions that the characters exhibit during the play. From there, I work to understand their individual polar attitudes toward the special physical, emotional, and psychological world at the beginning of the play and again at the end to discover who changes the most, who "owns" the play.

2.) The dialogue which relfects how the characters think, guides my examination into the speech of the characters. I take a closer look at the way the playwright articulates each character through choice of words, phrases, sentence structures, images created by the words, peculiar characteristis, sound of dialouge, and the structure of lines and speeches.

3.) The dramatic action addresses the conflict of the play. I rely on the subtext of each line help me to better understand the tactics of the characters used to obtain what they want. The tactics move the action forward, helping me understand the characters by revealing their true intentions. Dramactic action exists in present tense, as the characters remain in a state of doing. 
4.) Characters reveal themselves through the course of their actions. They can be summerized in specific actions After identifying the dramactic action of the character, I take the individual and break down the desire -what he/she truly wants. I examine the power of the character's will and how much strength they have to achieve their desire. I look at their morale stance which looks at the length they will go- whether they will break the law of church, state, or society. I figure out the character's decorum, their phycial manifestation of the state of mind, while adding adjectives to help describe them. The nervosity of each character captures their character-mood- intensity, cataloging the physical state of the character at rest, as contrast to flight and fight response.

5.) Idea examines the playwright's overall intention of the play by breaking down the meaning of the title and identifying the playwright's philosophical statements from the character dialogue. to discover parallel actions that reinforce those statements. After sitting with detail information, I focus on the emotion the production invokes through the themes and central concepts I believe the playwright wishes to portray. I then develop what I believe to be the overarching lesson of the play, the lesson the playwright wishes the audience to learn from their experience of the performance.

6. \& 7.) Tempo and Mood capture the designer's personal response to the play. The tempo of the play articulates the temporal progression of the story telling. By using a graph similar to an EKG. I map out the play unit by unit marking the inciting incident and noting the rising and falling action of each unit to identify climactic scenes and the climax of the play. Mood invites me to create a response centered on my five senses of sight, sound, smell, touch, and taste followed by a mood image for each of the units as 
connected to tempo. These two combine to create a personal response to the play as a whole.

After being introduced to the Hodge analysis and all of its part, I take an abbreviated version of the analysis (Figure 1.3), and try the technique on the American classic Tennessee Williams', A Streetcar Named Desire, our first spring project. Using this new tool to break down A Streetcar Named Desire, I find my strongest inspirations come from the records of my Hodge analysis (Figure 1.4). The play begins by introducing Stella and Stanley who live happily in New Orleans, the joyous home of jazz and all things colorful. The next moment, her sister, Blanche, arrives on the streetcar named Desire having come to visit or truthfully to stay, bringing her trunk filled with her lonely past and her heart filled with longing. Blanche immediately sets Stanley on edge igniting a dangerous relationship between Stella's two closest relationships, her husband and her sister. Blanche's very presence causes tension with their marriage, Stanley becoming irate with Blanche's aparent judgment of him and her flirtatious attitude towards his friend Mitch. He overhears Blanche confess that she lost the family fortune, which stokes the flames of his anger.

Looking back at this process, I acknowledge the challenge it was to switch from my undergraduate discipline to my graduate discipline. However, I find the project taught me how to look for the subtext in a script, which in turn helps me create a better understanding of the playwright's intention. Starting with A Streetcar Named Desire set my expectations as a candidate for the master of costume design, showing me the work I must put into each production I design. 
Streetcar takes place in a hot New Orleans summer in the late 1940s. The main actions take place in and around Stella and Stanley's small apartment which happens to be in a poorer neighborhood. People call New Orleans a melting pot, because the streetcar networks give the inner city a way to get to the upper city, a way to move easily in and out of the city. Jazz was born there, created from the combination of different cultures and music found in the city. Women became more independent from the image of the housewife because of WWII.

Williams uses previous action to recount Blanche's past, the loss of her young husband, her money and property, her teaching position and social standing, and her reputation once she began giving sexual favors to young soldiers from her resident hotel. At the beginning of the play, Stella believes in taking care of the people she loves, namely Blanche and Stanley. By the end of the play, she chooses to stand by Stanley, unable to believe what he did to her sister. Blanche changes the most in the play, as she struggles with her concept of reality and make believe. At the top of the play, she appears to know the difference between lies and fantasies. After Stanley's attack, she completely surrenders herself into her fantasies, unable to stand the world anymore.

The dialogue reveals Blanche's desire to stay a southern belle, speaking in a southern drawl and using southern phrases while Stella draws away from the slow southern talk. As an English teacher, Blanche uses rich words and proper grammar, while Stanley's words show that he has less education than his sister-in-law. Blanche can also enthrall people with the way she uses images in her speech. She blurs the lines of her reality and her fantasy, ensnaring Mitch while leaving Stanley suspicious. 
Blanche forces most of the action in the play, moving into Stella and Stanley's apartment and creating the rising tension that play builds itself upon. Throughout the play Blanche demonstrates her mastery of tactics. She performs, flirts, seduces, and teases all in an attempt to achieve the companionship she desires. At the same time she lies, deceives, hides, and criticizes to keep her past secret. She wears her trunk of outdated clothes to retain the image of a perfect lady, constantly washes her blonde hair to keep it fashionable and cherishes her belongs as precious remnants of her illusive past. She evokes the image of a fragile, delicate yet pitiful woman. Stanley suffers the most from her living in his presence for she challenges his intelligence, his heritage, and his power as a man and husband. In achieving his desire for control he confronts, instigates, threatens, challenges, berates, insults in going so far as to physically assault and rape Blanche to have ultimate control over her. He wears sturdy, functional work clothes, slicked back black hair and sleeves rolled to display his muscular tanned skin. I see images of a powerful man, well-built, handsome and loud. Stella, caught in the middle of the two forces comforts, entertains, chides and appeases. Stella's desire for affection leads her to be whatever either of them expect her to be. Stella has stronger morals than the other two and ironically a deeper sense of self. She keeps her hair simple and her fashion serviceable and appropriate for her youth and happy demeanor. A woman with kind brown eyes, a nice smile, and a young face transforms to the self-assured, responsible mother of her child by the close of the play.

The title, A Streetcar Named Desire, refers to streetcar outside the front door of the apartment. This streetcar and its destination, Elysian Fields, capture the true bookends 
of life and death selected by Williams to frame the play. Desire brings Blanche to this place and will lead to her afterlife in Elysian Fields. The title incorporates desire to point to Blanche, symbolizing her desires and what desires she brings out in the other characters. Blanche's attitude toward the special world comes from her fantastical life she has made up for herself, but Stanley represents the truth, or reality of the world. Stella becomes caught in the clash of Blanche and Stanley, fighting to keep herself from falling into the make believe. Yet, when Stella ignores Blanche's claims of Stanley's rape, Stella creates an imaginary world herself unable to believe her husband as the brute Blanche proclaims he is.

A quote to back up this concept comes from Blanche: "I don't want realism. I want magic! Yes, yes, magic! I try to give that to people. I misrepresent things to them. I don't tell the truth, I say what ought to be truth. And if that is sinful, then let me be damned for it!" (Streetcar, p. 145)For me, the play's central idea revolves around the idea of the concept of a person's fantasy and the dangers of building a fake world around you. With that thought, I create my bottom line of the play, which states: Don't let your desires consume your reality.

The all over tempo of the play reveals a fast rhythm, the tension building as the scenes progress leading to Stanley's rape of Blanche. As for mood, I smell smog and spices, taste sweat, feel static shocks, see blurs of vibrant colors through smog, and hear a base drum with a lone saxophone. These together create a mood image of a lone saxophone player covered in sweat as he plays in the smog of the city. 
With the in-depth analysis of the play assembled, I use my understanding of the play to begin my investigation into the design of the production. For unrealized designs, I act as both the director and costume designer creating the overall vision of the play. I create a single board full of images focusing on A Streetcar Named Desire that capture my physical, emotional, and psychological interpretation of the play's special world. This includes images of 1940s New Orleans, building structures, actual streetcars, and a melting pot of people. The emotional and psychological energy of New Orleans jazz greatly influences of the world of this play. Jazz rose around 1910, becoming a dance craze by the 1930s, then turned into the complex challenging style of music by the 1940s with the tempo becoming faster and more improvisational. The tempo and mood of the play unfolds as an erotic jazz piece the climax being Stanley's rape of Blanche. Pictures and paintings of jazz players bring vivid, bright colors flashing from the special world board. These clarify Williams' themes of the reality of sex and violence while pointing to the illusions of the secrets and lies.

With over a hundred images, I cull options to the most specific images selected to complete the special world board. A vivid, loud, and chaotic collage of images look back at me. A black and white screaming mouth in the middle of a board filled with color pulls focus as an internal anguished cry piercing through from the loud, brilliant, chaotic world. This translation of Williams' special world proves to be one of the clearest expressions of my project and strong foundation for all work yet to come. (Figure 1.5). These images capture my emotional response to the play while revealing the energies and themes of the production I wish to create. My greatest challenge comes in bringing these 
emotional concepts into the development of the clothes for the characters. This will balance on my ability to allow the clothes to conceal that "scream" masked by the clothes most of the time as the character/actor moves through the action until the appropriate moments for the character to reveal the inner chaos.

Capturing the true silhouettes of the time, 1930-1940, and the essence of each character becomes my next focus. The challenge of creating the appropriate profile as directed by the analysis and special world board, pushes me to accumulate extensive images of the clothes. I begin with primary source fashion anthologies containing images of the high fashion of the period. When presenting to my professor, she advises me to search for images of dress on real people rather than innovative designer fashion on exquisite models. The key to designing clothes for characters means that we look at real people on the street, doing everyday activities. I begin again with photography of real people by finding people participating in everyday activities parallel to these characters. Although sisters, Stella and Blanche dress quite differently especially given their personal histories in the previous action (Figure 1.6). What would Stanley wear bowling, given his personality (Figure 1.7)? What would make him stand out from Mitch and his poker buddies? What activities influence what they wear in their first encounter? What would they each have available to wear to a movie together?

Moving away from fashion books, I push towards black and white photographs, discovering great pieces for both female and male characters in more casual and everyday attire. Stanley and Mitch come to me more easily. Stanley dresses for casual personal comfort and freedom to express his innate energy and power which engulfs any space he 
enters. Mitch in comparison dresses more formally, reflecting the expectation of society and his mother's influence. After exploring various sketches, I decide to dress Stanley in well-worn ,tight- fitted blue jeans and a tightly fitted maroon T-Shirt, the sleeves rolled up to show off his arms to look more rugged while I put Mitch in slacks and a plain green color polo shirt (Figure 1.8). Stella dresses for comfort and practicality but still appears inherently sexy. She appears dressed to join the men at the bowling alley in a blouse with Capri pants, revealing a casual look that still exposes the shape of her body. This look proves to most clearly succeed in capturing the modern young 1940s woman that Stella has become. She reflects her world and allegiance to Stanley and his friends (Figure 1.9).

Designing Blanche presents the greatest challenge because of her complexity. Of all the characters her clothes need to provide opportunity to conceal and reveal that internal scream of my special world translation. Being held hostage by her past, Blanche believes herself to be wearing the elegant clothes of the lovely, pure, perfect lady she cherishes having been and so desperately wants to be again. She denies the reality of their old fashioned lines and textiles. Having little to no money she wears only the clothes she purchased when she taught English. Because of the quality of those clothes and her tender care for them to Stanley she appears to have money. The truth eventually reveals that she resided in a hotel, giving out sexual favors to young soldiers for money. Research into the dress of the 1930s allows me to introduce the concept of time lag into her choices. Here this means her wardrobe reflects the period in time when she could afford to purchase new clothes as well as her desire to hold onto pieces as symbols of her illusive past. "What does she carry in her trunk?" our professor asks. "What are the 
articles of clothing she would move from place to place and treat with great care?" She proceeds to propose a time when Blanche did have the money to buy elegant fashions. When the money ran out, Blanche took care of the nicest things she owns to maintain her image for herself.

Taking that idea, I move my research chronologically backwards. Instead of photos from the 40 s, I go to the late 30s, looking at high fashion then. The silhouette of the skirt slightly different than the 40s cut still fits into the same world. For Blanche's first costume, I look to traveling clothes from the 30s, finding a skirt, blouse and jacket ensemble. Accessories include a hat, gloves, and small purse, in a neutral tone. After drawing three different varieties of this look, I choose the one I think best represents Blanche. This soft and traveling suit on Blanche next to the snappy capris and blouse on Stella in their first encounter will immediately clarify how different they have become, how far away from each other they have grown (Figure 1.10).

Once I finish the sketches, I move to determining the colors and fabrics. Deciding upon these elements proves another challenge for me. The patterns I select not only have to be plausible to the vision of the production, but the pattern detail and color must be shown accurately in capturing the character truth and at the distance we determine in our performance space, the UVA Ruth Caplin theatre. These concepts makes looking for fabrics more perplexing. For the time, I realize that as a designer I must decide on fabrics by what fits the character instead of choosing swatches that appeal to me. Like every decision I make in designing, these must be thought out and clearly connected back to the character analysis and the world of the play. Wanting to portray the intense, vibrant 
life of the play through color of the world boards, I look for a vibrant colors and/or patterns to create a production of striking, violent color.

By the time I finish painting my color sketches, I notice that my color choices have taken on a lighter tonality. The swatches reveal the color I want, but light layering of paint and the silhouettes I drew of the characters give off a cheerful disposition relentlessly capturing the energy of the first moment of the play rather than the whole of the play. They appear almost as if to capture a musical theatre comedy version of the plan instead of a dramatic play.

That's when it hits me. These fabrics and colors do not fit the world of $A$ Streetcar Named Desire, but the realized production I am designing simultaneously- the musical production of the 1930s Wonderful Town. I had never encountered the challenge of designing two plays at the same time, one unrealized and the other fully realized. Their stories and characters being so different, the fear of one bleeding over to other never crossed my mind. But they did bleed over, and my Streetcar design suffered for it. Though my overall choices in clothes still work, the color scheme and cheerful poses of the sketches fail. My professor acknowledges the blending of the two productions and encourages me to revise at least six of the color sketches to incorporate the exact color and line I need to express these characters. I rework the colored sketches revealing a more realistic tonality, while still keeping with the rich color scheme I originally wanted (Figure 1.11). 
In truth, I am thankful for the failure as it proved a valuable lesson. As a designer, designing two or more plays at a time may be essential. Yet, a designer must be able to remain true to each vision. Re-reading the play, reviewing the analysis, special world images, and character research preserves the separation throughout that process. I learned how to use my preperation to better articulate the design and recognize that the designs required revision. I discover how to take a step back as a costume designer and look at my work through the eyes of a director and the audience. Reflecting on this first unrealized design, it reveals the importance and ultimate power of my deep analysis, personal connection, and commitment to the playwright.

My three years of graduate courses provides me with many unrealized projects from which to learn the art of design. Through these projects I learned how to step into the different soul of each play and character. I learned how to think of the project from the director's point of view and anticipate what a director may or may not feel appropriate in the design. These many things learned on my first unrealized project and subsequent projects brought me to my most recent and final class project, the challenge of Bertolt Bretch's The Threepenny Opera. This complex musical advances the themes and ideas of the playwright and the specific point of view of the character singing. The lyrics clarify the plot by furthering the philosophical and political ideas of the playwright. Brecht, along with composer Kurt Weill, created the musical by adapting and expanding John Gay's period play The Beggars Opera, set in $18^{\text {th }}$ century england. Bretch's play invokes themes of communism, hoping to gain the favor of the rising proletariat. Brecht 
believes in the working class, hoping they will gain power over the bourgeoisie, leading to a change of power in the political system currently run by the ruling class.

In The Threepenny Opera, the play begins with the the Balladeer singing of the dark and disturbing acts of the lead character Macheath, or Mack-The-Knife a notorious gangster in Soho. The scene changes to the shop of Mr. Peachum a man who makes his money by helping the beggars in Soho become better beggar. Peachum produces disguises, fake appendages, and signs to help these poor people obtain more money which they then bring to him. Basically, he pimps them out. He owns all of the corners in the town, and the beggars only beg with his permission.

Mr. Peachum's daughter, Polly, handles the book keepping for the operation yet one night he discovers that polly just married the gangster, Mack-The-Knife behind his back. Disapproving of the marriage, Peachum and his wife declare the criminal their mortal enemy and a threat to their business. They construct a plot to get Mack arrested and get their daughter, and best employee, back. However, the police chief, Tiger Brown, Mack's best friend from the war, turns his head to Mack's crimes allowing him to continue his life of crime. Polly lets this information slip to her parents, resulting in Peachum's blackmailing of Tiger Brown while Mrs. Peachum enlists the help of Mack's ex lover, the whore Ginny-Jenny.

Ginny-Jenny tells Mrs. Peachum she will sell out her former lover for ten shillings. When Polly finds out what her parents have done, she advises Mack to go into hiding and apologizes for getting him into trouble. Predictably, he ends up at 
the whore house with Ginny-Jenny who manages to distract him by reminiscing about their past relationship. The cops find Mack and take him away. At the jailhouse, Mack pleads to Tiger Brown's daughter, Lucy, another one of his former lovers. Unmoved, Lucy confronts him about his marriage to Polly which he denies. When Polly arrives at the prison, the two women quarrel over Mack who then rejects Polly, sending her away heartbroken. With a few seductive words to Lucy, she breaks him out of prison. The Peachums hear of his escape so Mrs. Peachum refuses Ginny-Jenny her money when she comes to collect. Tiger Brown arrives to arrest Peachum for allowing his beggars to roam during the coronation of the queen. He threatens Brown with the possibility that capturing the beggars now will corrupt the coronation and ruin the Brown's reputation. GinnyJenny betrays Mack again, this time to the police themselves.

Mack-The-Knife finds himself back in prison, this time with no escape. On his way to the gallows, he reflects on his past actions and begs for mercy in his grand aria. As the rest of the characters reach the gallows, a messenger comes from the queen, granting the release of Mack. As the crowd cheers Tiger Brown releases him. Mr. and Mrs. Peachum break from the crowd and directly address the audience. The two warn the audience that in reality, happy endings do not appear by way of messengers from the queen. Poor people's lives usually end in sticky situations, and men on horseback do not come and save them.

I read Brecht's play, recognizing the theme of injustice of society and the cooruption of government. Brecht uses the alienation affect, where he reminds and the audience that we are watching a play by having the characters constantly break the 
fourth wall, by turning to the audience and singing their songs. This musical accuses the government of being in the pockets of the criminals, and the middle class of being just as corrupted as the prositiutes and criminals. Brecht pushes us to focus on the ideas the characters express and not their personalities or individual circumstances. We are not to identify with the characters, but learn from them as personifying injustice and corruption or not.

The world of the play centers on Soho during the $19^{\text {th }}$ century. Researching Soho at this century, I discover the town used to be a prosperous part of London until the high society moved out and the brothels, gambling palaces and theatres moved in. The previously polished neighborhoods now look old, weathered and burnt out, decaying along with the people who try to live in the shadow of the culture's past life. These concepts of decay match the morals and the image of the characters, poor people who have no choice but to steal, beg, and prostitute themselves. The city overflows with corruption as reflected in decomposition of the environment, the citizens themselves and their visual persona created by the clothing they wear. I create my special world around this concept, taking images of broken buildings, oddly shaped bodies, and ripped and soiled clothing. I fill the world board with inspirational images of sex, viloence, and greed. The resulting chaotic world view visualizes the corrupt ideas of the play. This world view captures my bottom line idea of the play: Society thrives on the corruption of human kind (Figure 1.12). 
While presenting my idea of the decomposing world of this production, I describe the characters living in this world as having grey morals, with no judgement of good or evil. When I envision The Threepenny Opera, I see ammoral souls, people who have no real concept of good thus cannot imagine good or evil or act in any way good or evil. Brecht tries to show the audience a world where black and white does not exist and that every human soul shrouds itself in shades of gray.

As my professor and I work through the characters, I refer to images of the clothing and silhouettes from the 1890s. Before I speak further, she suggests I step back from the period and look back at my concept. In the past, one of my challenges comes when connecting my passions of the production to the clothing. I get caught in articulating the initial period of the piece, rather than allowing my concept and passion to drive my choice of period. Looking back at my inspiration board corruption and decay dominate communicating not time or period style but rather the decay condition of the world through layers of texture and discolored mismatched items. Reflecting back on the special world, I review my research of Soho. The wealthy society left for richer neighborhoods. What if these people, the people Brecht loathes, cast their less fashionable garments aside? What if the the prositutes, theives, and beggars found pieces of them, adding them to their collection? Maybe they actually wear these pieces or use these high end fabrics to mend their weathered clothes. Using this concept, I push forward to a less complicated silhouette of the early $20^{\text {th }}$ century which allows me to play with cast off garments from the turn of the century. (Figure 1.13). 
I decide to test this concept on one character to see if I can unite the clothes and the special world in this concept of corruption with decayed textures and dismantled clothes. I begin with Ginny-Jenny, a character who works as the head of the whorehouse. Her wardrobe relfects her occupation and status. I imagine her in undergarments throughout with her corset decorated in rich, vibrant fabric. Patches hide the wear and tear of years as a prostitute yet reflects her status and power over the other whores. Her only pair of stockings accumulate tears, barely being held up my her garters. Over her corset, she wears an old silk kimono, the luxurious fabric littered with rips and holes from cigarettes, grabby hands, and stumbling feet (Figure 1.14). When I finish sketching Ginny-Jenny, I see my concept of the clothes and the play coming together. Immediately the truth of the images from my inspiration board come through in the clothes creating the world I envision.

I launch into sketching all the characters with this consistent vision beginning with the number one criminal of Soho and protagonist of the play, Mack-The-Knife. As the leader of a gang, I first invision him in a three piece suit, but as I read the play further, the man symbolizes a grotesque type of freedom that could free him to dress however he likes while his personal power speaks of his status. He revels in his place in society, embracing the assumption that he is not rich. I envision him carelessly dishevelled, purposly appearing as if he cared nothng for appearances being one of his greatest lies. One of Polly's main draw to Mack comes from his uncleaned state, as she could not find herself attracted to a man with a stark white shirt and a pressed collar. The fewer layers show the power in his lean body, while also depicting his ungentlemanly behavior. By 
the end of the musical, Mack wears only a shirt and his pants, humanizing him in what he believes will be his last minutes of life.

Mack-The-Knife and Polly Peachum wed in the beginning of the musical. Through the theme of decay, the costumes symbolize the impurity of the marriage. Mack's wedding coat shows tears and mud stains while the silhouette of Polly's wedding dress comes from decades earlier than my setting date. The skirt and bodice reveals muck and grime on what should be a prestine white gown. A ceremony that usually sparks love and new beginnings instead exposes the lack of these ideas. Mack only marries Polly to have her. The clothes mean nothing to him. (Figure 1.15).

Being the wealthiest characters in the play, Polly and the Peachums wear higher fashion clothing than anyone else in the play with their silhouettes the closest to the actual style of the early 1900s. The peachums symbolize the middle class that Brecht preaches against. This family constantly deals with beggars, and they do live in the same low-rent neighborhood as their clients. Yet, they must identify with a higher status to maintain their power and control over them. The Peachum's take care to appear most appropriate, the opposite to Mack's expression of power and control. Wearing a day dress cut to resemble the early $20^{\text {th }}$ century, Polly appears to be the most fashionable of the women. However, she reflects the decay and corruption which seems to seep into her skirt, as though she pulled it from the muck and grime of the street. The Peachum's mimick Polly's look by wearing upper class attire, yet the clothes seem to be soaked in mud and water stains (Figure 1.16). 
Tiger Brown favors his friendship with Mack over the law he swears to uphold. Their close relationship goes all the way back to their time together in war, where the two men watched over each other. Powerful and driven to solutions of violence the other police stay silent about his friendship with this notorious gangster. As a policemen, and a part of the government, I choose to put Tiger Brown's in a traditional uniform and show the corruption through his patches and blood stains which cover what should be a pristine uniform. This reveals the crooked nature of the police chief, tying him closer to Mack than to the law (Figure 1.17).

Once completing the leading characters, I turn my attention to creating three ensemble groups who visually make up the surrounding atmosphere of the play - The Whores, The Beggars and Mack-The-Knife's Gang. They serve to support the principle characters yet blend into the setting of the play, creating a unity with the special world. Ginny-Jenny's clothes serve as the model for the whores with corests made of varied patchwork yet less vibrant but similarly distressed as the head whore. The beggars allow the audience to view the range of the poorest clothes next to the wealthiest members of Soho, the Peachums. Though their clothes resemble the same decay as the rest of the cast, their shilouettes follow the lowest class in society. Last, the clothes for Mack's gang create different silhouettes that match the personality of the characters name with all of their garments patched together similar to their leader yet with duller fabrics (Figure 1.18). Laying out the sketches, I see each character unifyed with one another, still maintaining a sense of individuality to their character. The colored sketches reveal the corruption the play articulates, while expressing my vision. 
In preparation for my presentation of this unrealized project, I sit quietly reviewing my presentation while listening to the Second Threepenny Finale, where Mack sings about how humanity stays alive by repressing the masses of the public. This song reminds me of how I view the play, of how Brecht talks about the corruption of the world and how the working class suffers the most. Every time I listen to this song my passion for this play reignites. Realizing this, I decide to begin my presentation with the song as the lyrics guide me back to my ideas while the music presents the ugly, corroded world I created. As the music starts to play, it creates a powerful confidence inside me. I feel a swell of accomplishment in my designs, as I reflect on unrealized designs of my past knowing my passions for them could never rival this project. The song ends. My voice steady, I begin to speak. I feel the words form in my mouth and trusting the power behind them, sense the certainty in what I am saying to my audience.

I end my presentation and await my feedback. The positive response confirms the decisions I have made in the process of this creating this design. My confidence does not come from the knowledge of the perfection of the designs, but rather from the success of taking a step forward in creative thinking, making brave, bold choices, and taking risks that could have perhaps failed yet have resulted in a cohesive vision. This last unrealized project reflects my growth from the previous years, and happily, the work supports the progression in my creative process as a costume designer.

Moving beyond reliance on my undergraduate lessons, I expand my analysis work from my realized work of The Rimers of Eldritch into my class studies of A Streetcar Named Desire. Through the journeys and challenges the plays present combined with the 
Hodge analysis process I learn to read between the lines. To understand a character, I break down the world which the playwright creates. I study every aspect of the text. The intense analysis exposes a deeper understanding of the play inspiring, pushing and expanding the previous boundaries of my creative process. I learn to use my connection to the script to assist in developing and articulating a strong concept of the production. With my final unrealized design of my graduate program, I discover how to successfully combine my analysis work with the designing of the costumes.

With The Threepenny Opera, I succeed in capturing the complex themes the playwright sets out to reveal and tie them into the clothes I design. I discover how to embrace my creativity and let my instincts win out over the fear of not translating vision into the design. Much like my process with the deconstruction, I break away from the creative block and succeed in moving forward. With a set discipline and a keen eye to analysis, I press forward, moving into the art of realized design and the art of collaboration. With my analysis work, I construct a vocabulary for myself that allows me to grasp the meanings and inner workings of the playwright. As I go through the collaboration process, I grow toward my mastery of costume design by creating a common vision of both my ideas and the ideas of the directors and other designers for performance before an audience. 


\section{Chapter 2}

When designing a realized production, I rely on my personal discipline to assist in creating a vocabulary to express my concepts both visually and verbally to the director and the design team. Through each design process, I communicate my vision of the production while drawing connections to the central concept envisioned by the director and the design team. Using a seven week design production matrix, we gather everyone together to create the foundation of the production, starting with the vision of play and building an image through research and sketches. This process brings the team together to focus on the play and production- Week 1: research, Week 2: character work, etc. Each design area moves step by step. The success of a working idea reveals itself by the seventh and final meeting when all ideas presented create a cohesive vision that successfully translates the play to fully design production. Two of my most recent productions demonstrate the demand of the vastly different challenges presented by the plays and the subsequent variations in communication and collaboration applied to achieve successful productions both of them achieved through this process.

The Triumph of Love, a French play set in the $17^{\text {th }}$ century, calls for the focus of the essence of the period silhouette in the clothes and how this essence influences the style of all of the design. The production demands detailed research of the period, while also exhibiting the same understanding of the characters. Throughout the design process, I follow the step-by-step elements of the design matrix. Each week I present a new step, creating the building blocks of my process. When I switch to the design of Shipwrecked! An Entertainment: The Adventures of Louis De Rougemont (as Told by Himself), I follow 
a more organic process. Though the matrix still pertains guides me, the play calls for different types of exploration and discovery. The script calls for the design team, director, and actors to build the story of the script through rehearsals' experimental exploration, allowing us to create the overall interpretation of the play. 


\section{The Triumph of Love}

\section{by Pierre Marivaux Translation by James Magruder}

The design team for The Triumph of Love combines graduate students, undergraduates, a faculty scenic designer, and a guest director. The combination of the different minds excites me, each of us bringing both experience and ideas. The talent in our team creates a smooth confidence that moves us forward. Before we assemble, I diligently apply the Hodge analysis to this $18^{\text {th }}$ century play repeating many of the same steps as I described previously while acknowledging the differences in analysis of plays written in this century. (Figure 2.1)

The Triumph of Love, written in 1732, tells of an unusual journey in finding love and what a person will be willing to go through to find it. A young princess named Léonide disguises herself and her saucy servant, Corinne, as men in pursuit of a young prince, Agis. The young man lives under the roof of her arch-rivals the philosopher Hermocrate and his sister Léontine. These two siblings despise the princess for the actions taken previously by her uncle, who usurped the crown of another king. Her uncle did not know, however, that the fallen king had an unborn son who escaped from his grasp. The princess now rules over the lands by right of ascent, and while looking for the lost prince, happens upon him in the forest and falls in love with him at first sight. Hermocrate has raised the unknowing prince to loathe the young princess condemning her leadership, warning him that she would kill him if she knew he was living. 
With her love for Agis guiding her actions, Léonide and Corine, now disguised as their male counterparts Phocion and Hermidas, infiltrate the philosopher's garden, determined to win the prince's heart. She will, then, give the throne to him, the rightful heir, and become his queen. To distract Phocion and Hermidas from her seduction of Agis, Léonide plots to fight the cold-hearted siblings, with the thing she understands most, love. She secretly fabricates confessions of love to each of them separately, all the while creating a close bond with Agis. By the climax of the play, all three of these characters have fallen in love with her. At last, Léonide reveals her true identity and her true intentions to all three, departing this garden with the besotted prince, Agis, in tow.

Princess Léonide creates the disguise of a woman with stubborn, calculated determination, and questionable morality. She orchestrates a grand scheme, having more than just one plan in motion. Though she demonstrates little to no regard for manipulating two lonely souls to hope of achieving her love, she stops at nothing to achieve the love of Agis. The development of character and character relations and the comic elements expect a light touch for a modern audience to look favorable on Léonide's commitment to Agis.

When The Triumph of Love originally opened in 1732, the play received ill reviews because of the Léonide's conduct throughout the play. The audience felt her behavior lacked the values of a respectable woman. Although she presents as a resilient individual who fights for her desires, her actions break societal norms. She demonstrates a strength and deception inappropriate for a female to reveal. She fights for what she wants without reservation. This being quite audacious for the period audience proves 
much more typical for a contemporary audience. For this production, my development of the playwright's idea focuses on the proactive force of Léonide. 'Being loved gives you strength, while loving gives you courage.'(H. Tynes)

After my instinctual interpretation of the play, I launch into the general characteristics of the play's period. Having studied the History of Dress in the my second year, I clearly understand the $18^{\text {th }}$ century and the evolution of silhouettes of the three sequntial silhouettes of the Georgian Period. Reviewing the variety of silhouettes, I recognize the importance of focusing carefully on the specific silhouette we select to prevent the accurate excess of this century from overwhelming the character and the actor. To keep from getting lost in the century's evolution of fashion, I gather specific research which speaks to the individual characters.

I educate myself on the gradual change in the shilouettes through the Early, Middle, and Late Georgian periods. I recongize the way the length's of the men's waistcoats travels from the knee up to the waistline. The standing collar of the coats rise high enough to turn back down, cuffs move from wide elbow length thumbsback to the sleeve fit shorten to rise just a few inches above the wrist. Women's underpropper, the pannier, begin by gently widening the hips to grow to exaggerated extensions of finger tip to finger tip width then dissapear completely with but a single pad center back by the end of the century. The understanding of the evolution of the silhouette helps me determine that the simplity of the late century will best support the characters/actors and the production. 
Having thoroughly read the play and gained an essential understanding of Georgian fashion, I now sit in the first design meeting ready to discuss our thoughts on this play and its production. After introductions, the director explains to the group that he picks keywords to help create the world he envisions. For this play, he gives us the words- Light, Airy, Fun, Soft, and Whimsical- prompting a discussion of what they could mean regarding the design. Images of the words flash through my mind. The tone of the play follows these ideas, but when I think of the garments of this period, I feel the weighty layers and fabrics of the Georgian garments. They express a femininity that the play rarely invokes when I read it, especially when all but the dowager sister wear men's clothes. My idea focuses on the independence and strength of our leading lady. I hold those thoughts, keeping my mind open to these new ideas.

I decide to try and connect the strength I perceive from Léonide while invoking the feminine words the director gives me. I use paintings from the period to aid in creating the world of the play. The pictures I find most inspiring do focus on the female as central to the image. Paintings that spark my interest range from depicting two female friends and ladies with men situated in a flirtatious manner.

Reviewing the paintings, I realize the pictures I draw the most inspiration from come from the same painter, Jean-Honoré Fragonard. This French painter's most famous works consist of his genre paintings which convey an air of erotic intimacy. The pictures depict a soft line, while the colors and the content invoke a light- hearted, whimsical atmosphere. I narrow my focus two of his works, in particular, that I believe translate the vision of both the director and myself. The Stolen Kiss depicts a simple yet elegantly 
dressed respectable young lady caught by a young man who steals the kiss by pressing his lips to the shocked lady's cheek. The picture reminds me of young love, the act to us innocent, yet sparked with intense emotion. The passion in the painting makes me think of Leonide's first discovering with Agis, looking at him from afar. The young man of the painting does not see the emotion he ignites in the young princess. Nor did Agis know the impression he left on Léonide The Musical Contest portrays a young woman flanked by two adoring men, held captive as they watch her sing a ballad. The scene prompts me to think of Léonide ensnaring the two siblings with her outrageously seductive techniques. The colors of this piece express the vibrant energy of the world of the play, while the lines of the background creating a light and airy scene (Figure 2.2).

The Swing, also known as Happy Accidents of the Swing, remains Fragonard's best-known work. The picture portrays a woman on a swing, being pushed by her husband, the shadows hiding him from sight. A young man lies just under the brush with full view of the swinging woman, catching a glimpse under her skirts and petticoat to her nether garments just as she kicks off her shoe. The lady herself reveals a sly expression, well aware of the lad hiding in the brush (Figure 2.3). The painting expresses many of themes similar to our production. The woman, the main character of the piece, demonstrates power while she swings into the air, feet kicking out in a playful manner. She seems fully aware that the lad, perhaps her lover, can see her undergarments, all the while her husband pushes unaware from behind unaware. Her personality resembles Léonide's, acknowledging the power of her sexuality. The softness of these paintings 
along with Fraganard's use of color and form create a whimsical world while the lightness depicts an airy feeling.

Using these images, I create an inspiration board, each painting reflecting my vision of the play. I look up well known lines about love, strength and determination attaching them alongside the paintings. The visual aid articulates the variety of lines, colors, shapes, and themes capturing the concepts the collaboration team discussed in the last meeting (Figure 2.4). Presenting the images in the next design meeting, I discuss how the quotations lead back to my bottom line. Using the three paintings, I discuss the softness of the lines, the capricious worlds created by the colors, and the central focus of the woman. The director takes great interest in the painting of The Swing, stating that for him this image captures his idea of the world of the play. He feels a connection to the lightweight impression of the image and the setting of the picture capturing the idea of the philosopher's garden.

Successfully discovering a way to visualize the inspirational words, I move forward to express those ideas in the clothes. I go back to my previous research of the period, trying to figure out how to incorporate the concepts while staying true to the century's fashion. The Georgian style combines a hundred years worth of research. As I dig deeper and deeper into specific details, I find myself losing the point of the play. I become so focused on whether I take to the fuller jackets of the Early Georgian period or how full the skirts should be that I push myself further away from who wears the actual articles of clothing. The design fails the moment I lose the character. 
In search of a solution I step back from the detail. I let myself hover around the essence of the period, not focusing on the date of the research, but of who I find in my journey that relates back to the characters. I start with the two disguised women in the play- Léonide and Corine. The two women wear men's clothes throughout the piece, but to find out what they would wear as men, I must research what they would wear as women. As the princess, I imagine that Léonide immerses herself in high fashion. Certain colors and combinations catch her eye being wealthy enough to wear whatever she pleases. Though she has a strong personality, Léonide embraces her feminine side. She discovers her power in her sexuality, using the fullness of her gowns to show off her power. Pictures of Georgian women in soft dresses adorned with decorations invoke the leadings lady's figure. One of the things I find important in designing Léonide relies on her attachment to womanhood. I imagine the princess dressed as a man, surrenders power of her skirted fullness to the narrowness of the male silhouette even though she would now be observed as a male with assumed inherent power. Instead of creating power from the width of her gowns, Léonide uses the slickness of a tailored garment to show off her curvacious female body. The cut of Léonide's suit disguises her womanless yet reveals the silhouette of her feminine curves through the careful tailoring of the coat. Her suit should be the most fashionable of the entire company.

Corine, being her maid and confidant, creates her garments from what bespeaks her position assumed to be less elegant than her mistress. As I imagine what the woman, corine wears I assume an informal uniform while working with her daily attire coming from an assortment of garments. Where Léonide's clothes create a full attire, Corine may 
wear a collage of patterns and colors. I look to images of maids in different color skirts and bodices. The young girl's personality rivals our princess with her saucy attitude creating an equally strong image. Corine's male disguise as Hermidas resembles the disguise of the princess in silhouette, but the coat, vest, and breeches create a simpler look than that of the princess. To express the difference in their status but still connect them reinforces Corine's loyalty to Léonide as an important aspect of the play. Though Leonides garments rely on excellent tailoring, Corine's clothing creates a simpler, less tailored silhouette. The cut does not entirely hide Corine's feminine curves, while Leonide's tailoring shows off more of her figure. The difference in line will help distinguish the two women from each other while keeping the power with Léonide (Figure 2.5).

Our two philosophical siblings, Hermocrate and Léontine, both believe the same philosophy. 'Fools focus on love while learned men and women devote their lives to the pursuit of knowledge.' They avoid their feelings to focus on logic, rather than meddle in the trivial pursuits of the heart. Their pride justifies their denial of their foolish behavior resulting in extremely comical attitude. Hermocrate's persona inspires two possible images. I could create a disheveled academic throughly out of fashion or create an overly fashionable gentlemen, prissy and precise. The man cares about how people percive him both in looks and knowledge. I decide to make him a gentleman who wears tailored, fashionable garments of the period. Hermocrate's fashion choice falls behind the cut of Leonide's ensemble as the long lines of the man's coat create a gangly appearance rather than a stylish one. 
While Hermocrate creates a long narrow form, his sister Léontine's figure, I craft a full, wide shape. Léontine's attitude resembles that of a shrew. While I imagine the princess's female garments as soft and light, I picture the older woman with a heavy, bulky weight. I become drawn to the polonaise for her, a style creating a dense, fuller silhouette from the hips down yet drawn up to reveal the ankles giving the character a too narrow base for stability. Léontine resembles her brother in not having a keen eye when it comes to fashion. Though she dresses a bit more fashionably, I make her skirt shorter, creating an oddly awkward proportion with bird feet supporting her mass (Figure 2.6).

The servants, Harlequin and Dimas, reflect the lowest status among the characters. When I think of these two clown-like characters, I see their attire at opposite ends of the spectrum. They are both servants, yet they could not be more different. Their comradery relies on their shared passion for money and their lustful fascination with women, Corine in particular. Though Corine falls into the same status as the two male servants, she holds more power over them. Harlequin, the philosopher's butler, wears the cut of a gentleman's attendent, though mimicking Corine in the mismatch of breeches, waistcoat, and coat. While researching Harlequin, I discover pictures of waiting men in either the mismatched attire or a more uniform look. Given the location of the garden the more informal look seems most appropriate for him. Although the cut resembles the rigid silhouette of Hermocrate, the simple fabric impiles a lower status. As the working gardner, Dimas dresses like a peasant. The man takes charge of the gardens, proud of the 
dirt and grime he wears. The gardeners that I find in different paintings and drawings of peasants, appear bulkier and wider in cut than of the high-status men (Figure 2.7).

I best communicate my ideas through drawing, which comes easily and quickly. I pull the correct lines and shapes from my research, the characters transfering from the lead of the pencil onto the white paper. I can quickly create mulitple options from a single research image to give the director many different choices. When I present the sketches to the design team, along side the research from the previous meetings, the ideas come through sucessfully. With the aid of the drawings, the director visualizes how the different cuts of coats and the tailoring of the clothes become the characters. The sketches receive mostly positive feedback. Any critique I rectify right there, using my abilitiy to draw quickly to erase and redraw the prefered line. Now that we see a clear vision for the characters, I turn my attention to color.

Before I decide on my color pallet, I search the fabric stores in the area. I discover that upholstery and drapery fabric provide the appropriate weight and patterns of the late Georgian period. I gather samples of colorful silks, cottons and linens. As my options grow, I realize that somewhere through the process, I unconsciously pull farther away from the extravagant fabrics and pull colors and prints that invoke a more subtle nature matching that simplicity of the Late Georgian. The colors change from a wild vibrancy to more organic colors. Beige becomes a primary color connecting with the green and pink tones. The color intensities and values remind me of The Swing while the dominate blue hues give way to beige, green and pink hues of the clothes, connecting this image is more consistent to our vision. 
I lay out my samples, creating two color concepts: one of the vibrant silks, velvet and outragous patterns and another of organic colors with heavy cottons, linens, and smaller patterns. I present both of the ideas to the group, arranging by color intensity and pattern. As we all look at the samples, the scenic designer presents his color sketch of the set. We take in the beige and gray marble and the blue sky filled with clouds, which spill onto the floor as if the primary platform floats in the skies above. Immediately, I remove all of the samples that contain the cool colors, seeing that the blue and purple tones would fade into the set. Those colors belong in the wild contemporary options which now look small and not as grandiose without the cooler tones. The greens and pinks along with the beiges lay next to the colors of the set beautifully, creating a breath of life along the Grecian marble. I position the characters into three groups, the first the two women, the second the siblings and the prince, and the third the servants. As I intuitively assign the different color samples, I notice a pattern to my choices. The pink and orange tone fabrics fall to the young women, while all my green hues go to the brother, sister and the prince. The servants accumulate the brown swatches, and every group finds different shades of beige and creams.

The scenic design brings me back to the image of the garden. The servants being the lowest in status, represent the dirt and underbrush. The siblings and the prince create the foliage of the garden, growing up and around the greenery of the estate. The two women from outside the estate appear in the shades of rose and pink, the flowers of the garden. In the play, the author sets the production in the philosopher's garden. While the scenic design plays with the Grecian setting which the script calls upon, I decide to 
use the colors of the clothing to invoke the colorsof the garden surrounding the arena of the storytelling. This ties the environemt and character together with the different tones of beige used throughout the designs.

By the time I narrow down and collect all the perferred fabric choices, the audition and callbacks for the production begin. I attend the callbacks with the director, bringing my favorite samples organized by the intended character. As I observe the actors readings I refer to the color sketches and their swatches, seeing if my choices match the energy of the character as portrayed by various actors under consideration. Following callbacks the director and I move to the Ruth Caplin theater where the production will be performed. I lay the sketches out on the edge of the stage before us, placing the samples beside them. The director and I walk around the sketches, pulling away to create the distance from them to see where our eyes travel. We play the game of switching out some of the samples by either giving them to another character or taking them away entirely. I bring extra samples to test. They tell us how different colors shift character intentions. By the end of our meeting, we agree on these results satisfy our needs. The next meeting falls days later, allowing me to present the final colored sketches of the characters with their accompanying fabrics. All worked together as a whole. The scenic designer presents his final design allowing us to determine if the relationship between the characters and their world prove successful. At this point we discover togther that Hermocrate wearing a beige diamond pattern coat and breeches becomes lost in the midst of marbles and clouds. My advisor suggests that instead of revisiting the fabrics I switch the waistcoat, green with a small vine pattern, with the coat material. I hesitate at first, worried that the 
character will look out of place with matching breeches and vest and a contrasting coat. Then I realize that my original concept for Hermocrate relied on his inability to be fashionable. The man wearing a two- piece suit with a different coat, indeed shows a lack of style.

As the design meetings end, the director and the design team agree that we have succeeded in creating a vision from the director's initial words - Light, Airy, Fun, Soft, and Whimsical. At opening, the world of the play creates a whimsical, fantastical atmosphere as the characters clothed in light, airy clothes enact their story in the clouds. The colors of the costumes create a soft, light illusion within and around the pastel lighting of the marble surround, while the tailored lines differentiate the styles of three piece suits. The vision the collaboration team worked so hard to create becomes what the titles states- A Triumph of Love (Figure 2. 8).

Having successfully collaborated to create The Triumph of Love, I move forward to my final realized design of my graduate studies. 


\section{Shipwrecked! An Entertainment:}

\section{The Amazing Adventures of Louis De Rougemont (As Told By Himself)}

\section{By Donald Margulies}

Embracing a new challenge in designing clothes for Shipwrecked!, I the immediately recognize that the written script has no stage directions. Only the dialogue of the main character as story teller will guide the director and design team in their work. This allows us, the director, designers and the actors, to create our own visions of the story. We mold the world which the script depicts, knowing that the story we tell will be original and built from our creativity.

The Shipwrecked! begins with our leading man, Louis, telling the stories of his spectacular sea fairing adventures accompanied his two players. We start in his childhood, where he reveals his love of adventure and escape from reality by losing himself in them. His thirst for adventure leads him to a boat with a captain and the captain's crew of pearl fishermen. On his adventures he discovers sea monsters and rare treasures stopping only when in a horrid shipwreck. This leaves him and his dog, Bruno, on a deserted island. There he remains stranded for years, until Yamba and her family come to the island. They create a life together, Louis joining the aboriginal tribe. When at last he leaves the island and makes his way back home to England, he shares his amazing stories with anyone who will listen. There he earns the reputation as a true adventurer. As the plot unfolds, the playwright reveals the stories Louis tells us to be nothing but figment of an old man's imagination. The two supporting players realize the adventures he 
seduced them with, he simply made up. So they chalk it all up to up to delusions of grandeur. Louis defends his stories and as the play end the players and the audience depart either doubting that any of this ever happened or hoping that these adventures actually did happen (Figure 2.9)

The stories remind me of a child playing pretend. As Louis invokes the images of his tales, he invites his players to join him in creating the people, the creatures, and even the storm that strands them. The play's primary idea centers on the act of make believe and hiding from reality by creating fantastical worlds. The playwright proposes to demonstrate what happens to people who submerge themselves in fictional worlds and happenings.

As I sit in the first design meeting for Shipwrecked!, I feel the charge in the atmosphere, bodies tired but minds ready to create. The director settles in her seat wih the script held tenderly in her hand. Her insight into the story centers on the concept and process of believable storytelling. People love stories; they love to hear them. Even more, they love to believe them. The enticement of the production comes from the stories the actors perform as Louis narrates them. The audience revels in experiencing the many different worlds and imagining them possible. The power of the imagination builds their hope in the truth of the stories while they discover that these may not be true, creating a deep sense of disappointment.

Talking together about the storytelling guides me back to my childhood and the look on the face of a child totally captivated when listening to a story for the first time 
while being inspired to create their own stories. My mention of this memory leads in the design meeting to share similar thoughts. The sound designer acknowledges that his experience with reading a story for the first time creates an emotional investment in that story. These encounters help our team realize the power of immersing ourselves in this story and the need to let our own emotions become impacted by the tale if we hope to succeed in telling these stories to our audience. We pledge to create a production that invokes the same emotions of hope that we feel.

With this initial foundation, the director leads us to the idea of people believing what they want to believe. She asks the design group what we think of Louis' tales. Personally, I believe the stories to be false. I think the playwright wants the reader to lose themselves in the world that Louis creates, only to be brought back to the surface by feelings of doubt and uncertainty, an experience Louis goes through as the players turn on him. The playwright intends to create an atmosphere that leaves the reader questioning what truly happened. Our conversation leads to the director's beliefs that the theatre possesses the power to create stories for the audience. People often think of theatre as a type of entertainment which intends to hold one's attention. To gain their attention, we as artists must encourage the audience to believe the story. In collaboration we must inspire the audience to embrace the events of the story and then experience the disappointment in their not being true. Once the curtain falls, the decision of whether or not to trust Louis' stories falls to the audience.

As we continue to share our thoughts, I share with the group my experience of reading the play for the first time. I imagine children running around, creating fantastical 
characters screaming for fear of a frightening sea monster as grand as only their wild imaginations could create. I envision the children discovering pieces of cast off clothing closest to them, trying them on, filling them with meaning and creating a whole new identity. I think back to Louis, an old man who deludes himself into believing in the reality of his experiences. Instead of this old man, I see a ten-year-old boy who never truly grew up. Like Peter Pan, he prefers the world of lost boys, fighting pirates and hunting Indians; he finds himself on a stage reenacting his own fantasies (Figure 2.10).

The meeting continues with deep discussion as each designer creates new insights for the rest of us. Though we express our ideas differently, the members of this design team share parallel visions. We all talk of our experience regarding the script, each of us picturing the acts in the story grand and epic, yet feeling that sense of betrayal with the revelations that the stories may be false. Breaking apart from the deep discussion, the director brings us back to the primary setting of the play. She envisions the play in a Victorian world, setting the actions around the same time Louis' tales unfold, which ranges from the late 1800 s to the turn of the last century. While script calls for only three actors, the director decides on 10 to 12 players to push the actions to a high level of energy. This choice will fill the stage with more people, each of them creating parts of the world to aid that image (Figure 2.11). This addition will prove to be a challenge in the design, as I began my analysis work with two players instead of ten. I now must factor in twelve Victorian silhouettes instead of three.

I think back to my original reaction to the play as a game of pretending, and how that coincides with the director's vision. Children play with a reckless abandon, oblivious 
of the clothes on their back or the environment around them. The restrictions of the identifiable Victorian silhouette do not allow for such abandonment but rather the restrictions maintain a stiff, rigid shape. The layers and layers of clothing from the confining corsets and petticoats to the starched collars and tight fitting tailoring constrain movement in complete opposition to our fluid modern day shapes, flexible, stretchable textiles, cut ad fit. Freedom of movement breaks away from the constraining profile. How do I create a figure free from a restrained Victorian silhouette?

I search books and online sources, to discover contrasting lines and shapes built for a comfortable, athletic Victorian society. Where could I find the wild wreckless soul of Louis, those child-like deliquents from the Victorian norm? In my process, I discover pictures, not of straight-backed couples or blank face expressions but of a Victorian lady, pushing her nose up and crossing her eyes at the camera, Victorian men hunched over, tounges out and face scrunched as they pose for a picture. These all deviate from the normal images usually selected to reveal the conformity of the time (Figure 2.12) These pictures show me that no matter the rescriction of the clothes, it does not change how people express themselves.

In Shakespeare, we read of clowns, of sword fights, of running through enchanted forest. The silhouette, cut and weight of the Elizabethan underpropers and clothing restrict more than any clothing of the Victorian Era. We could assume such movement impossible. What am I missing? What is the factor I am not considering? At last I recognize that I must consider the will of the character/actor to find physical expression despite the perceived and very real restrictions of the period. In fact, the 
greater the challenge perhaps the clearer expression. The characters still perform their tasks. I vow to abandon my enslavement to the Victorian era and focus on the characters' expression and movement. The world of Louis' imagination comes to life through the playing of the troupe.

The script, casts two other actors to invoke the other forty or so characters that Louis imagines. The director decides to cast more than that, which inspires me. What if the players address themselves by the actor's real name. By each one playing these many different personas they resemble a period theatrical troupe. Inspiration hits me. I envision the basic costumes mimicking the identities of the actors, dressing them in a Victorian silhouette that speaks to their style (Figure 2.13). When I bring this concept to the next meeting I discover the scenic designer's inspirational photos reflect my idea. With pictures of old Victorian theatre she explains her vision of these theaters as similar to a ship. She shares images of wooden stages and how they could represent the bows of the ship; the ropes of the fly system could become the ropes to the ship's sails. Clearly the extensive discussion from the first meeting has brought the scenic designer and I to create coexisting worlds combining the elements of storytelling and the theatre structure.

I delve deeper into the design possibilites. The acting troupe shows one layer of the play. Louis tells his story through the reality of the narration, yet the story he tells pulls us into a different world. Throughout the play, the playwright bounces the audience from one location to the other. I think of the simple act of playing pretend, of how a child creates a character from a simple object. Children never create a character from the ground up. They build the new persona by either adding or subtracting pieces they find in 
their environment. A stick can become a mighty sword while a towel transforms them into a caped superhero. A feather boa makes a little girl a fashionable lady whereas a bandana around the neck turns a child into a bandit. Instead of designing full costumes for each character, the idea of the actor, in their base, adding things to their costumes will best serve the evolving action of the story telling. Louis's mother, for example, puts on an apron as she does the laundry. The maternal connotation of this apron signals Louis and the audience that this actor now portrays mother. Captain Jensen, the sea-faring captain that takes Louis on his grand adventure, adds a tricorn hat, a Georgian jacket, and the proud stance of power and status immediately become symbolic of the adventures Louis always wished for (Figure 2.14).

As the director and I discover more about the many personalities throughout the story, we find our choices stemming from a the sterotypical image the character invokes instead of relying on a formal character analysis. Each character's drive centers on the character Louis bestows on him or her through his narration of the story. We both decide that the design of the character comes not from the depth of detail and analysis, but from how Louis's child-like imagination sees them and what the actor brings to the creation of this particular character. Item selected for their immediate recognizable connotation with support the audience in identifying the character. For example, the Austrailian prospectors who find Louis and rescue him from the island wear large brim cowboy hats, with hankercheifs around their necks. The society ladies, portayed by male and female actors wear the pieces of a matching garment, acessorizing with large decorated hats. The reporters who denouce Louis's good name take on the appearances of our favorite 
sloothes, Sherlock Holmes and John Watson, one wearing the famous deer stock cap with the other wearing a bowler hat (Figure 2.15).

Yomba, Louis's aboriginal wife and her tribe, prove to be the biggest challenge. The director requests that we stay away from any stereotypical look of aboriginals. She worries about how we might portray the aboriginals without offending. Childhood memories of images from National Geographic depict the painted faces and bright fabrics of a young tribesman and his little girl. This proves to be everything the director wishes to avoid in the design. I contemplate that image. What is the most noticeable difference between aboriginal and European fashion? Layers!

Aboriginals lives center on the natural. They wear little to nothing in the form of clothing, creating their own style of body cover. Their sense of modesty differentiates them from Westernized culture while the way they wear their garments allows great physical and spiritual freedom. Children also have little sense of indecency, not yet being socialized. I remember my older brother running around in nothing but his underwear for most of his preschool days. I propose to the director that we do not add an article of clothing to symbolize them, but instead, have the actors strip off their Victorian layers. Both men and women could wear modest undergarments from union suits to bloomers, petticoats, chemises, and corsets. Each character can be in different states of undress. Undressing gives the aboriginal characters a physical and spiritual freedom and wildness as compared to their European counterparts (Figure 2.16). 
With the costume design solidifying in the actions of adding and subtracting, the scenic design also plays with this concept. After many variations, the idea of an old 1900s theatre became the main construct. The idea of the acting troupe being too poor for set pieces, the scenic designer devises that the actors create the set from hanging planks, crates, and trunks. The trunks and an old rolling rack will contain most of the clothes.

Shipwrecked! shows two different worlds, the one in which Louis resides and the one he narrates. Because the two worlds have different energies, I see two distinct color pallets. One contains a dull pallet made up of neutrals, cool and saturated tones, the other vibrant, hot, and warm tones. The scenic design consists of an entire theatre painted to resemble wood, invoking the essence of the $19^{\text {th }}$ century. Different shades of brown cover the area, as well as the creates and trunks. The paint on the wood contains red tones, life breathing into the world when the lights hit it just right. The acting troupe enters with Louis dressed in saturated colors and Victorian silhouettes presenting the impression of a serious play about to unfold. Then troupe scrambles to reveal the trunks and rolling rack. With high energy, almost like a flower blooming in front of their eyes, the action begins.

Collaboration rarely breathes so easily. These successful production meetings center on the design group listening to each other, taking small pockets of conversation and subconsciously transforming them into the design. From the imagination of a Victorian theatre's resemblance to a ship to the creation of victorian actors in their own victorian clothes adding and subtracting period accessories, we follow the insight of the director, letting it fuel our process. Our understanding of not only the play but of each other as artist and unquie visionaries drives the success (Figure 2.17). 
During the process of The Triumph of Love I show how I use the design matrix to aid me in developing my designs step-by-step by breaking down my thought process, staying on track and keeping me focused on the ultimate simplicity of the playwright's idea. I apply my knowledge gain from my History of Dress class, and how to use that knowledge to help create the profile of the individual characters and their relationship to each other and their special world. With the vision of the director and the design team as the focal point, I use the essence of the period to reveal the true themes and bottom line of the play.

Shipwrecked! An Entertainment The Amazing Adventures of Louis De Rougemont (As Told By Himself) challenges my flexibility and persistence in creating clothes for storytelling with a play, unlike Triumph. Shipwrecked! invites me to use the script as a baseline to create the vision of the piece through the collaboration of the actors, directors, and designers. Describe as a devised piece, this production design process forces ongoing invention and experimentation. I learn to constantly relate back to the main ideas of the play and vision of the director and design team to create new ideas and design elements as the actors and directors begin to make discoveries of their own through their devising in rehearsal. This production teaches me to think fast and use my creative process to figure out and solve any obstacles that may arise.

With each opportunity to design costumes, I grow in understanding the in and out of how to collaborate with other artist in the creation of a strong and precise production. My private discipline evolves with each show as each script presents new challenges and each director and design team brings new understandings to how we create the work. All 
of us focus on the audience and the relationship of the play's idea to the culture they embrace. With each opportunity I learn to pursue what inspires me toward the next. 


\section{Chapter 3}

When it comes to mastering my creative process, I concentrate not only on my process in costume design, but also on my growing process in costume technology. Understanding the way to read a script and create the clothing only carries me as far as the completed color sketches with fabric swatches, accompanied by mounds of designer paperwork. This prepares me to move into the costume shop, executing these costumes for the performance before an audience on opening night. The process of embracing technology and its accompanying multitude of skills that must be mastered proves challenging. Yet, we cannot possibly learn all the techniques. What we truly learn focuses on the process of problem solving in getting the clothes to the stage and the invaluable talented people who surround us move the design ideas to the stage. Yet, this has been a journey with much to learn.

I remember the first time I ever dealt with sewing, the foundation of costume technology. In junior high, my assigned home economics class project expected me to build a pair of pajama pants. At the time, the sewing machine took on the resemblance of a monster, something only a knight could overcome. I struggled with the process, certain that failure loomed on the horizon. Witnessing my distress, a knight in the form of a senior came to my aid, walking me step-by-step through the process. The completed pants earned me a B+, yet on that day I swore I would never touch a sewing machine for as long as I lived. Flash forward to the present, where I most recently completed patterning and building two skirts for the upcoming production Blood Wedding, while simultaneously cutting, constructing, and fitting one of my unrealized designs and a ballet 
bodice. (Figure 3.1) I often think back on that moment with the pajama pants, amazed that the 'me' of the past has chosen a career that relies on my ability to do what once scared me so much.

Like discovering the Hodge analysis I begin to build my costume technology skills through my first technology class, learning the art of couture techniques. By cutting out samples of different types of fabric, I test my skills in mastering over fifty different techniques used in creating high end couture garments for the fashion industry. The mastery of these techniques prepare me to apply them to any challenge. I begin with hand stitches, from a basic stitch to a baseball stitch, the catch stitch, and even the hand buttonhole stitch. The technology professor also teaches us many different machine stitches, including multiple seams, plackets, pleats, finishes, and more. (Figure 3.2). Though I did sew in my undergraduate costume shop, I find myself struggling to keep these graduate stitches straight and narrow. Like the samples from my technology, I realize my desire to perform at a face pace keeps me from perfecting the stitch. I push towards getting the stitch done and keeping up with the samples rather than perfecting the craft. I tell myself to slow down and focus on excellence by really putting dedicated effort into my couture samples. This realization helps me to understand the importance of each stitch, and being able to classify them on other garments. I keep all of them organized in a large container, labeled and ready to pull out to solve stitching challenges.

Taking both a technology class and a design class each semester challenges me to focus on the balance essential to accomplish either one or both together. Technology being my greatest challenge forces me to concentrate on the growth of these skills and 
how they inform my work as a designer. Coming into the department in pursuit of an MFA in costume design and technology immediately put me on notice to build my technology skills from the ground up.

Patterning and draping assignments challenge my ability to combine 2-D and 3-D visual thinking as I imagine the steps to a finished garment. I find that every sloper I build shows progress in understanding the constructs of shape. Draping becomes easier as I realize I can fully comprehend the 3 dimensional work of draping even though I struggle with the creation of the flat 2-D shapes. I realize my brain understands the manipulation of the fabric on an actual dress form. With each build of these slopers, my confidence in patterning and constructing clothes grows. How I used to approach a sewing project becomes different from how I did in my first year. My assurance in my sewing skills grows as I feel confident in taking on new projects.

My corsetry work demonstrates my growth. For three terms we focused on building a different period corset. This corsetry work helps us understand the silhouette of the period, the progress of the female form and shape of fashion. I start with the 1890s corset, with a busk in the front and no straps. This silhouette creates an hourglass look, yet has a more relaxed form than its predecessors. This first corset teaches me the basic steps to each corset, helping me understand the construction of the garment as well as the importance of the boning. I learn how to insert a busk with button holes in the front of the corset, while setting grommets and lacing it up the back. I create this corset out of a light reflective silk satin pattern. The overall construction challenged me because of slipperiness of the satin fabric, the cutting of the bones and center front alignment. 
Despite the challenges, when reviewing the finished product I feel proud of my accomplishment.

The Georgian corset, in which the boning at center front replaces the 1890s busk, finishes at the waist tabs extending onto the hips which splay out from the waist line, across the hips when it sits on the woman. This style of corset raises the breasts while tightening the mid drift. I build this corset from a gold silk, finding the corset a bit simpler to put together. My main difficulty came in finishing the waist tabs neatly with bias binding. Some tabs completed more neatly than others. Again, I preserve, and even though my finish work may not be up to the standard I was hoping to achieve, I finish the project.

My latest corset proves itself to be my most successful. Using a cotton for this quilted Empire Period corset I purchase a color fabric base with a darker thread to machine quit on the top. By the time I build this third corset, I easily recall the steps and techniques of the previous corsets, mostly guiding myself through the process. I finish this corset quite early, having finished the other two only the day before they were due. I had days to spare between my completions of the Empire corset and its presentation. This accomplishment proves to me that my skills in understanding construction and applying that understanding have sharpened (Figure 3.3).

While reviewing my strengths and weaknesses in technology, I find myself pleasantly surprised at the quality of my techniques and aesthetic millinery. In crafts my last fall term, we build three different types of hats: a Victorian hat, a felt cloche hat, 
and a wire framed hat. My talent and passion for design translate readily to the design and execution of millinery. It allows me to make character choices with the variety of materials and techniques I decide to use. Decisions for final decorations belong to me. This connection of design and technology spurs my love for millinery work.

The first hat allows me to work with buckram, cutting the pattern of the hat and hand-stitching wire around the edges to keep them stable. I choose to build a Toque style hat, which looks similar to a small top hat. I decide to play with the recent "steam punk" style of design in creating the decor of the hat which might be used in creating Alice in Wonderland's Mad Hatter. After hand sewing the buckram pieces together, I decide to cover the hat with a purple velvet, using purple trim and red fabric flowers as decoration. I chose a thin red fabric as the inner lining of the hat, adding a mult-colorful feather on top of the hat as a finishing touch. (Figure 3.4).

For the felt 1920S cloche hat, I find myself drawn to creating pleats on the brim of the cloche. I choose a forest green felt hat blank, shaping it to the head form before altering the hat by cutting off the bottom half of the cloche brim. I steam the pleats I wish to create in place, pinning my desired shape of the pleats and leaving them to set over night. After my pleats set, I sew the brim back on to the crown of the cloche. Once connected, I cover the seam with a vintage ribbon. I study the cloche, feeling as though it needs something more. Wanting to keep it simple yet wanting to bring focus to the pleated brim, I decide to add two small buttons at the top of the first pleat to bring the eye to the brim (Figure 3.5). 
Feeling my confidence grow with the creation of these two hats, I decide to challenge myself with the wire frame. While watching BBC 1980s mini-series Pride and Prejudice, I recognize one of the lady's bonnets as being built with a wire frame. Finding a photo of this hat online, my professor encourages me to take on the challenge. I begin building a pattern by manipulating brown paper into the perfect size and determining how many rows of wire I will need. Unlike the other hats, where we had directions to follow, here I determine my own solutions with the support of my professor. Through my research image I decide to have four rows of wire, holding them together by using four points of wire at the front, back, and the sides. I construct the brim with one wire, making the outer edge and holding it in place with three other wires. As I construct the hat frame, I keep an eye out for organza fabric to cover the hat. I want the bonnet to be light and airy compared to buckram or straw bonnets I am accustom to seeing. I discover a dyed maroon organza in stock, deciding to cover the hat with this. After covering and hand stitching the fabric onto the wire, I decorate the hat with a large peach ribbon, a sweet bow tied into the back. (Figure 3.6)

My graduate study teaches me the importance of costume technology to my costume design career. I discover that mastering the technology gives me the knowledge of how to build the garments that I design, and the ability to articulate the design and what the sketches needs to clearly communicate to the cutter/draper. It all builds on the art of communication and vocabulary. I use the analysis vocabulary to pursue the works of the script. I create a vocabulary with my director and other designers to express the main vision and design. Now I use vocabulary to guide my communication and 
collaboration with the technologists in the costume shop who will bring these sketches to life successfully.

Moving towards the execution of the costume designs for The Triumph of Love, I meet with the technology professor and the Head of the Costume Shop to create a plan for the weeks these designs will be in the shop. Previously during the design meetings I examine our Late Georgian stock and find plenty of 17th-century shirts as well as coat, vest and breeches options for the two servants, Harlequin and Dimas. Deciding to pull their costumes, I conclude that we will need to focus our build on the remaining five characters. Because of a short time in the shop for such a heavy production build, the fall term period draping class will focus the remaining class time building muslin mock-ups of Late Georgian breeches, waistcoats, coats, and a polonaise gown. The class builds allow me to start the spring semester with mock-up fittings for the show, while also familiarizing me to the lines and shapes of the Late Georgian period. With the fabric purchased before the break, my cohort and I can come back from the holiday break ready to fit the mock-ups and begin the cutting, then construction and finish work.

In collaboration with the technology professor, I assign each character to a MFA student, myself included, based on the perceived level of experience. One of my colleagues takes on all three garments in the design for Corine, while the other focuses of Léontine's polonaise design and Hermocrate's breeches and waistcoat. Our fourth-year shop assistant builds the waistcoat and breeches for Agis, and our professor builds coats for Hermocrate and Agis. My passion for the character, Léonide, leads me to take on her breeches, waistcoat, and coat (Figure 3.7). With the builds assigned, I start to call in the 
actors. Each technician aids me in the fitting, allowing me to use different types of communication with each one to help benefit both of us and the character design. I make sure to keep plenty of research handy just in case they have questions and need to refer to it. I provide each one of them with a copy of the colored sketch asking them to keep this nearby while in fittings and during the construction period.

I first call the three female actors for corset fittings as even the two in men's clothing will wear corsets. While designing the show, I decide to keep the women in their proper undergarments because I wish to preserve the period silhouette they have grown into as children wearing corsets. I want the audience to see the women struggling to impersonate the men, for these women come into this state of dress on the whim of Léonide. The corsets change the line of the silhouette of the mock-ups, succeeding in capturing my initial concept. For each actress, we tailor the coat to reveal the feminine curves. Corine's takes on a more relaxed line, while Léonide's fit captures her attractively slim, corseted silhouette.

For Léontine, we build different size polonaise mock-ups, unaware of the size of the actresses to be cast at the time we created mock-ups the previous fall. Fortunately these will fit our actress. From stock I pull all of the proper undergarments of the period need to create the fullness of her silhouette. Extra petticoats and bum rolls support the desired width of the skirt. When I get to the men, I use the mock-ups and tweak the lines for each character. I exaggerate the tall and lanky frame of the actor playing Hermocrate by lengthening his coat to create the ideal gangly figure the director and I wish to see in contrast to his wider, fuller sibling, Léontine. With the character Agis, one of the mock- 
ups fits his body-type perfectly, giving the actor broad looking shoulders and a slender cut through the rib cage.

The fittings happen in a week, turning the focus of the shop to cutting and building the three-piece suits and the polonaise gown. Having purchased the fabrics in the fall semester, after each fittings the technicians go straight to correcting the patterns and then to cutting the clothes from the fabric. With cutting well underway, the shop manager pulls me aside to discuss the details of the garments, such as the buttons for the coats, waistcoats, and breeches. I look to the costume and scenic renderings, choosing between gold and silver buttons or fabric covered buttons. As I debate the options, I decide on the fabric buttons, worrying the metallic aspect of the former will cause more of a distraction under lights. As the shop manager orders the right tools for creating the fabric buttons, I choose the fabrics for each of the style. I decide the breeches will have matching fabric buttons, while the vests and coats will show complementary color design as in the color sketches.

While a shop assistant creates the buttons, I turn to researching the hair for the period. Because I want the femininity of the two women in disguise, I design the two women to use their natural hair. The other characters, however, need a more polished late Georgian look. I search through our wig stock, finding two well-maintain men's wigs, and both in natural brown toned hair colors. I set them aside. With the time frame short, my original idea of styling the two wigs becomes a low priority. Instead, I decide to order the two wigs, with plans style them to fit the show. Yet, this proves not to be the last thing that falls by the way. As these other duties pile up, I begin to struggle juggling my 
responsibilities as the designer with my desire to build all three pieces of Leonide's costume. The breeches and waistcoat come easily enough though I allow myself to take time, wanting them to come out beautifully. The tailoring of the period coat becomes my main issue as I struggle with the bulk of the fabric and the setting of the sleeves. As the first parade draws near, I realize the coat will not be completed in time. I remember the director asking in one of the rehearsal reports how I felt about Léonide taking off her coat for a majority of the performance, the director envisioning both her and Agis losing layers as they fall more deeply in love, allowing greater freedom I immediately contact him, explaining the predicament and asking if for the first dress parade we might see Léonide only in her waistcoat and breeches. He responds positively wanting to take the publicity photo of her without her coat regardless of its completion for the parade (Figure 3.8).

When we reach the second dress parade, we examine Léontine in her polonaise gown. As the only character in a woman's period silhouette, I discover that I neglected to put the necessary completion detail on her gown. She looks like a simple shell of fabric cut in the proper silhouette. She appears bleak in comparison to the male suits around her. Her technologist and I take a look at the gown the next day in the shop. Setting the dress on her mannequin, we discuss how to make Léontine's costume stand on its own among the others. I pull trims from our extensive stock asking for her technologist to chime in. After looking at a dozen options, we narrow it down to a beautiful gold trim, zigging zagging down across her stomacher and finishing her sleeves (Figure 3.9). After adding the trim, I look to my color sketch to see what I actually drew. I see I have scalloped lace 
furbelows at the elbow as per tradition and a white fishu at the neck of the bodice. I pull these accessories from stock and arrange them on the gown. Immediately, the garment begins to express more of Léontine's character personality. Yet, I still feel hesitant. I ask advice from the shop team. Brainstorming for a solution someone suggests fabric flowers down the stomacher. I agree and add flowers there and in her hair. By dress rehearsal Léontine fits into the world of the characters, holding her own while still fitting into the special world the production and of the characters (Figure 3.10).

As the dress rehearsals proceed, I watch the actors move realizing for the first time in this hectic production process that these people wear clothes I designed. They came from my imagination just a few months ago. Creating a successful 2D image brings great satisfaction, but seeing my color sketches come to life- one of them being built by me- inspires a new feeling of pride. Though proud of the realization of my design, I also feel tremendous achievement from the way my communication at all levels has results in this 'triumph' on stage.

Having completed three years of graduate school, I now embrace the field of costume technology. With the talents, teaching skills and patience of my technology professor combined with the opportunities I have been allowed to have, I find myself becoming passionate for sewing. I find myself looking at garments in the store with a thought that I could build that, or removing it from the hanger to study the construction. I find myself seeking chances to sharpen the skills I obtained in these years. I see my designs connecting more to the way I build the costume, seeing understanding the 
challenges in a build as I create a sketch. Because of my opportunities to learn and practice my understanding for construction guides me as I design, helping me fully realize my work as a designer. 


\section{$\underline{\text { Conclusion }}$}

Looking back to my deconstruction project, I mark the first real breakthrough I achieved in my creative growth. I come back to this project as the first step of sculpting my inner artist, leading me to the accomplishments I have made in the past three years. Each technique I cultivate reveals lessons and discoveries that push me further towards the mastery. The MFA Costume Design and Technology program here at the University of Virginia has given me the opportunity to push past my boundaries as a designer and a technician. I accomplish things I never saw myself doing, surpassing who I thought I could be as an artist. The lessons I have learned and the experiences I have gained make me realize I am not the same designer that came into this program three years ago.

At the end of my three years, I see my confidence in my collaboration growing with each show. My new found sense of ease in talking with a director and designers grows from working with different people and designing different styles of plays. I create a better relationship with my fellow designers, each show I work on revealing stronger teamwork and united visions. I have learned to ask questions to help myself find the ideal vision with the director and design team, creating cohesive visions.

Though always having had a knack for drawing, the pace of my drawing gains more speed and accuracy with character expressions with each production I sketch. I came into the program with a stylized way of drawing, my characters taking on greater similarity to animation than to real people. Now as I move forward into the professional world, my style has becomes more realistic, proportions correcting themselves through 
my professor's teachings. Using my speed helps me easily revise drawings instantly, keeping up with the design process and showing my director that I can invent find multiple solutions quickly. I am flexible. Transforming my presentation style more closely matches the style of production than before as the play becomes more important to me.

My understanding of the period styles grows with each production I design and garments I construct. My education in History of Dress inspires my love for all of the different fashions throughout history, learning how political and social changes inform the change of silhouettes. I find that the history I learn in costuming can also influence the story of the play, these questions being a part of the analysis work I do with each script and supporting my understanding of the playwright inspiration to write this story as a reflection of his/her own culture.

Each production I pursue advances me further into my mastery, sharpening my skills in both design and technology. My creativity shines through all my work, each one evidence of my talent as well as my growth as an artist. These works allow me to embody my creative spirit. As I finish out my last semester in my graduate education I discover a readiness to face the new challenges of the professional world. I will continue to learn through new experiences, using my education to propel me further. I leave this department three years wiser, older, and above all else, a master in my art. 


\section{Appendix: Introduction}

\section{Table of Contents}

I.1 The original photo of the Kyoto coat and skirt, (right) the paint copy of the coat and skirt

I.2 Original 1790s Georgian fashion plate and ensemble into the fashion plate

I.3 Thomas Gainsborough painting and the ensemble into the painting

I.4 The deconstruction of the ensemble 


\section{Appendix: Chapter 1}

\section{Table of Contents}

1.1 The Rimers of Eldritch by Landford Wilson production photos

1.2 The Rimers of Eldritch special world

1.3 Copy of the abbreviated Hodge analysis created by Gweneth West

1.4 A Streetcar Named Desire My abbreviated analysis

1.5 A Streetcar Named Desire special world board

1.6 A Streetcar Named Desire character board of Stella and Blanche

1.7 A Streetcar Named Desire character board of Mitch and Stanley

1.8 A Streetcar Named Desire color sketches of Stanley and Mitch

1.9 A Streetcar Named Desire color sketches of Stella

1.10 A Streetcar Named Desire color sketches of Blanche

1.11 A Streetcar Named Desire original color sketches matched with their revisions

1.12 The Threepenny Opera special world board

1.13 The Threepenny Opera research pictures

1.14 The Threepenny Opera color sketch of Ginny- Jenny color sketch

1.15 The Threepenny Opera color sketches of Mack-the-Knife, Act One through Act Three and Wedding with Polly Peachum 
1.16 The Threepenny Opera color sketches Polly and Mr. and Mrs. Peachum

1.17 The Threepenny Opera color sketches Lucy Brown and Tiger Brown

1.18 The Threepenny Opera Group Plates of the Gang Members, The Beggars, and The Whores 


\section{Appendix: Chapter 2}

\section{Table of Contents}

2.1 The Triumph of Love, featuring the young lovers

2.2 Inspiration from Jean-Honoré Fragonard paintings

2.3 The Swing by Jean-Honoré Fragonard

2.4 The Triumph of Love special world board

2.5 The Triumph of Love Léonide and Corine Research and Color sketches

2.6 The Triumph of Love Léontine and Hermocrate Research and color sketches

2.7 The Triumph of Love Harlequin and Dimas Research and colored sketches

2.8 The Triumph of Love production photos

2.9 Shipwrecked! An Entertainment: The Amazing Adventures of Louis de Rougemont (as Told by Himself) production photo

2.10 Shipwrecked! An Entertainment: The Amazing Adventures of Louis de Rougemont (as Told by Himself) inspiration pictures of children playing pretend

2.11 Shipwrecked! An Entertainment: The Amazing Adventures of Louis de Rougemont (as Told by Himself) Pictures of Victorian research

2.12 Shipwrecked! An Entertainment: The Amazing Adventures of Louis de Rougemont 
(as Told by Himself) Pictures of silly faces in the Victorian era

2.13 Shipwrecked! An Entertainment: The Amazing Adventures of Louis de Rougemont (as Told by Himself) color sketches

2.14 Shipwrecked! An Entertainment: The Amazing Adventures of Louis de Rougemont (as Told by Himself Group plate of the story characters part 1

2.15 Shipwrecked! An Entertainment: The Amazing Adventures of Louis de Rougemont (as Told by Himself Group plate of the story characters part 2

2.16 Shipwrecked! An Entertainment: The Amazing Adventures of Louis de Rougemont (as Told by Himself) Aboriginal sketches

2.17 Shipwrecked! An Entertainment: The Amazing Adventures of Louis de Rougemont (as Told by Himself) production photos 


\section{Appendix: Chapter 3}

\section{Table of Contents}

3.1 Process photos of Polly Peachum's Dress, The wedding skirt from Blood

Wedding and a Ballet Bodice from creative draping, Spring 2017.

3.2 Technology couture samples, Fall 2014

3.3 Corsetry work throughout my graduate career:

3.4 Victorian Toque Hat Costume Craft, Fall 2016

3.5 1920’s Cloche Hat Costume Craft, Fall 2016

3.6 Wire framed bonnet Costume Craft, Fall 2016

3.7 The Triumph of Love Leonide's fall front breeches, waistcoat, and coat

3.8 The Triumph of Love production photos of Léonide wearing her ensemble

3.9 The Triumph of Love Publicity photo

3.10 The Triumph of Love close up of decorated stomacher and additional trim, lace and fishu on Léontine's costume

3.11 The Triumph of Love production photo 


\section{Appendix: Conclusion}

\section{Table of Contents}

C.1 Shipwrecked! An Entertainment, the Amazing Adventures of Louis De Rougemont (As Told by Himself), The Rimers of Eldritch, and The Triumph of Love production photos. 

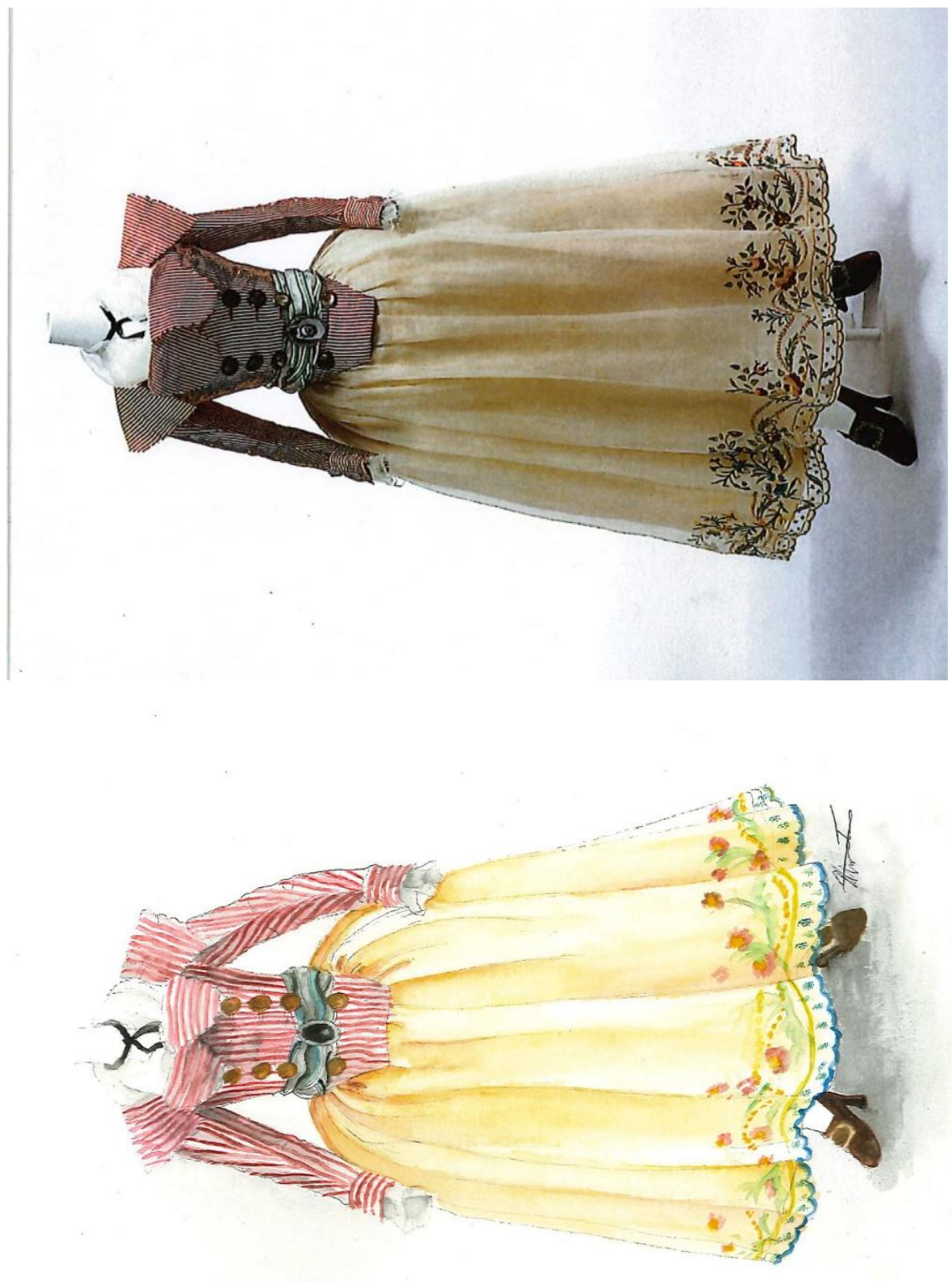

Figure I.1: The original photograph from the Kyoto Collection of the jacket and skirt (Left), and the paint copy of the jacket and skirt (Right). 

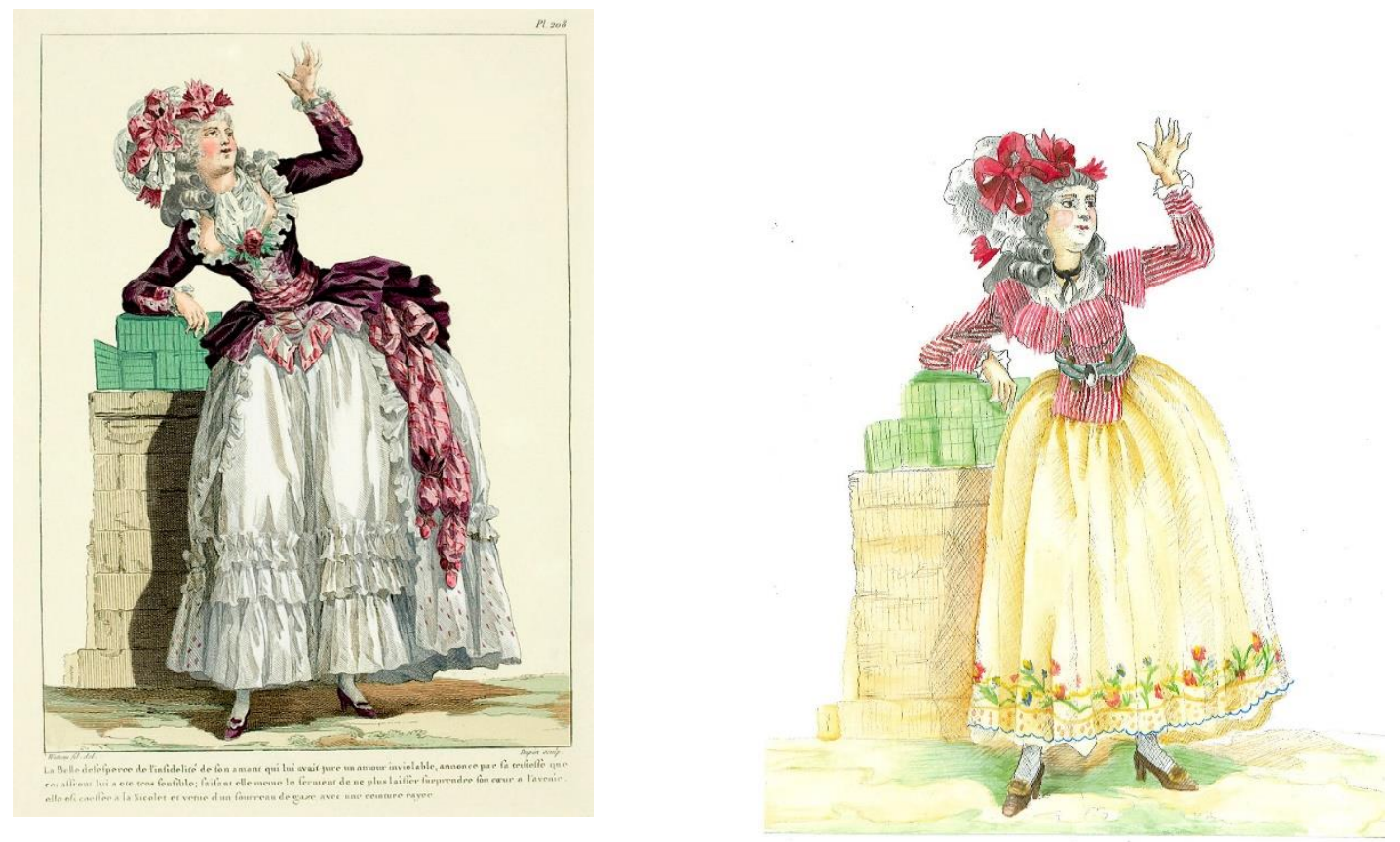

Figure I. 2: Translating the original 1790s fashion plate (Left) with my ensemble fashion plate (Right)
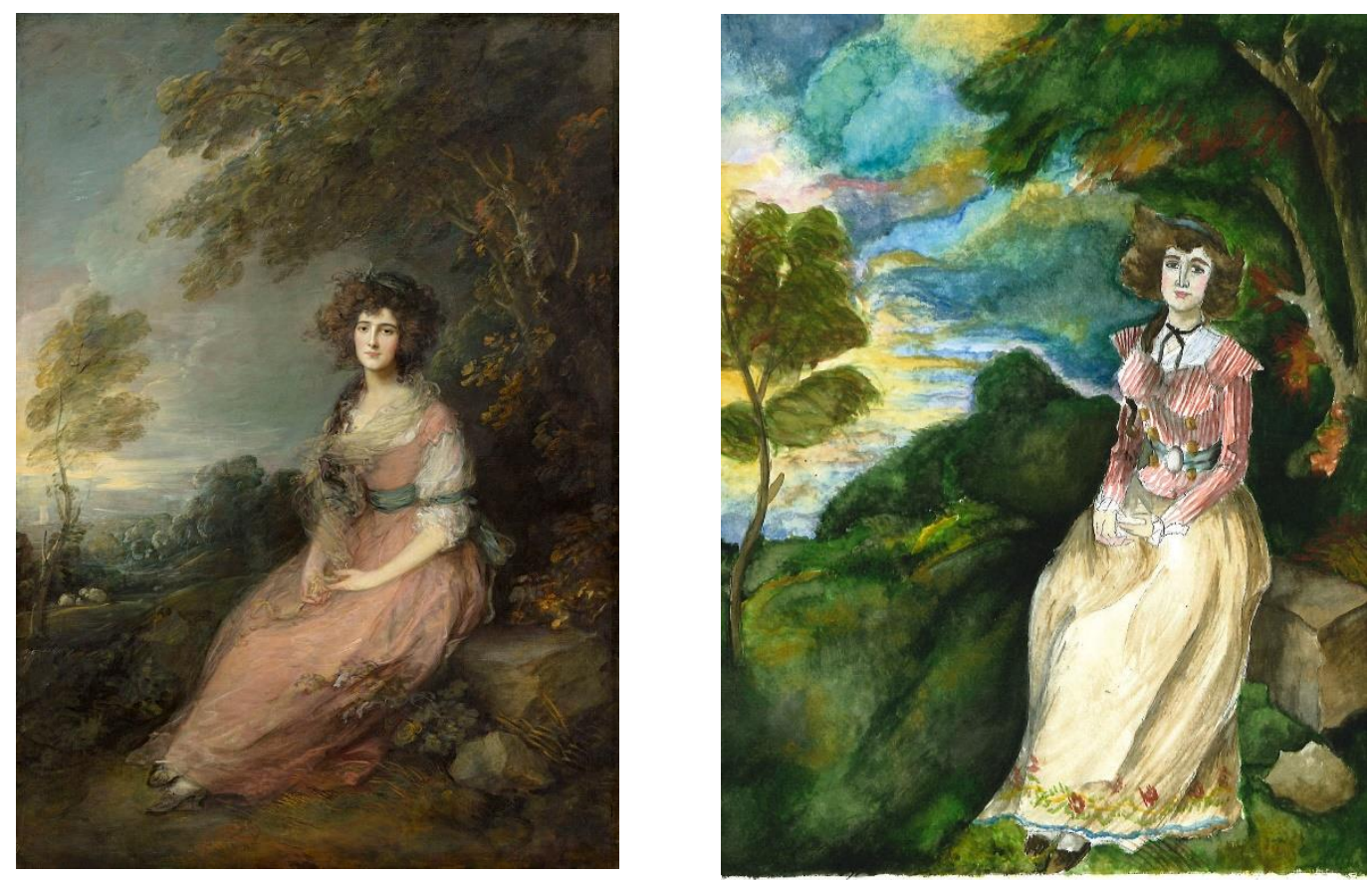

Figure I.3: Translating Thomas Gainsborough painting (Left) into a painting with my ensemble (Right) 


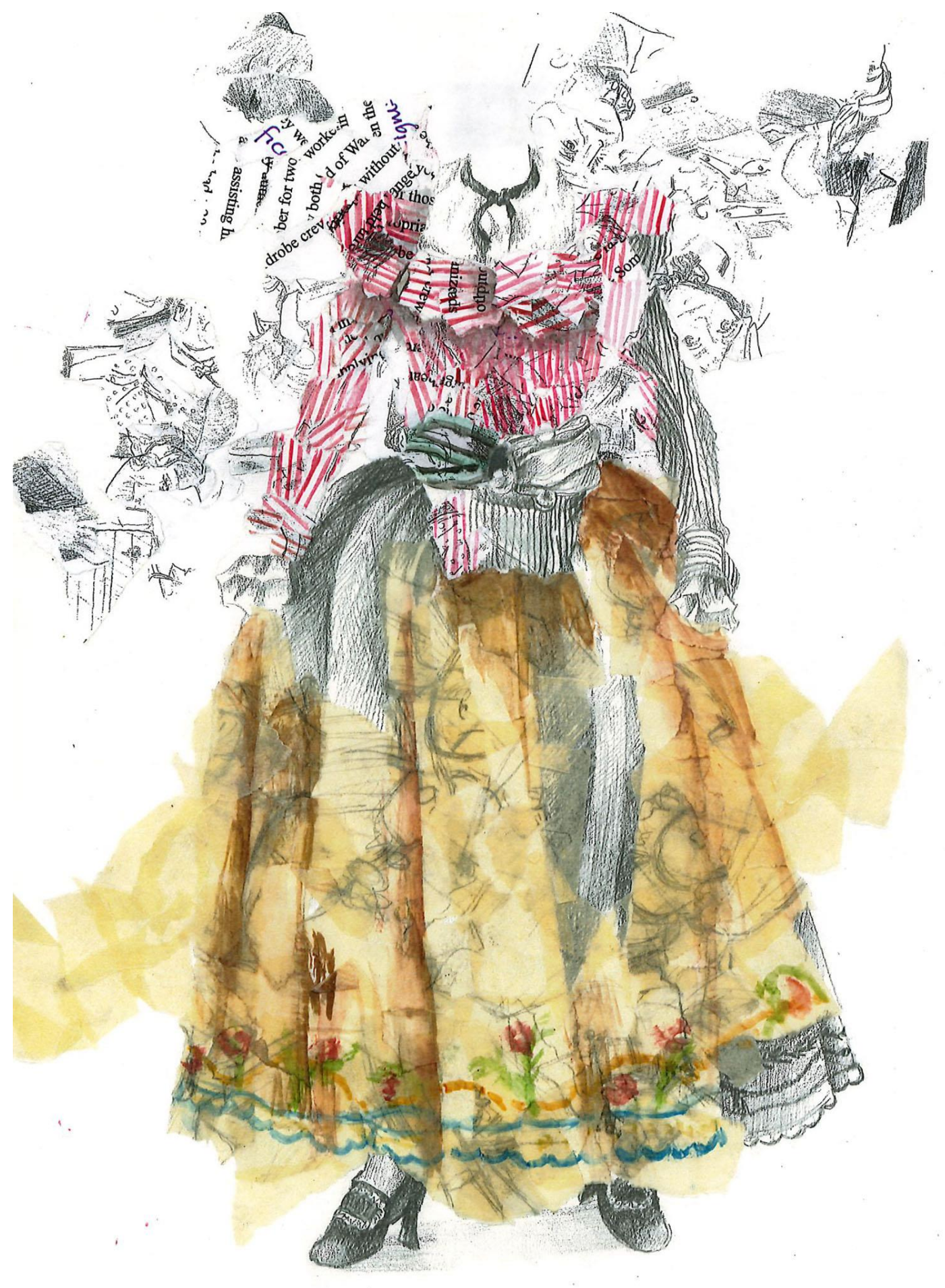

Figure I.4: My final deconstruction of the ensemble 


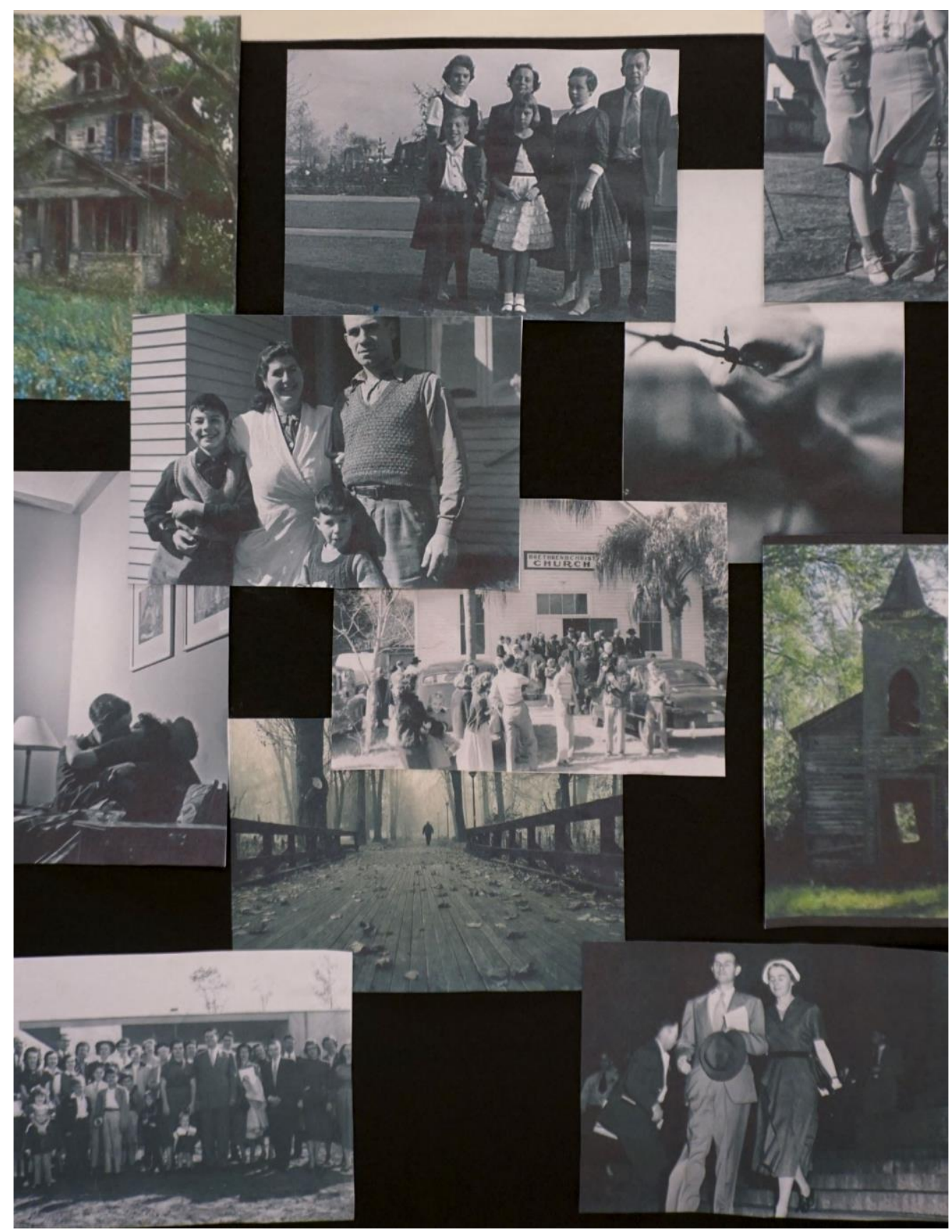

Figure 1.1: The Rimers of Eldritch special world board showing pictures of community, period research, and inspiration photos. 

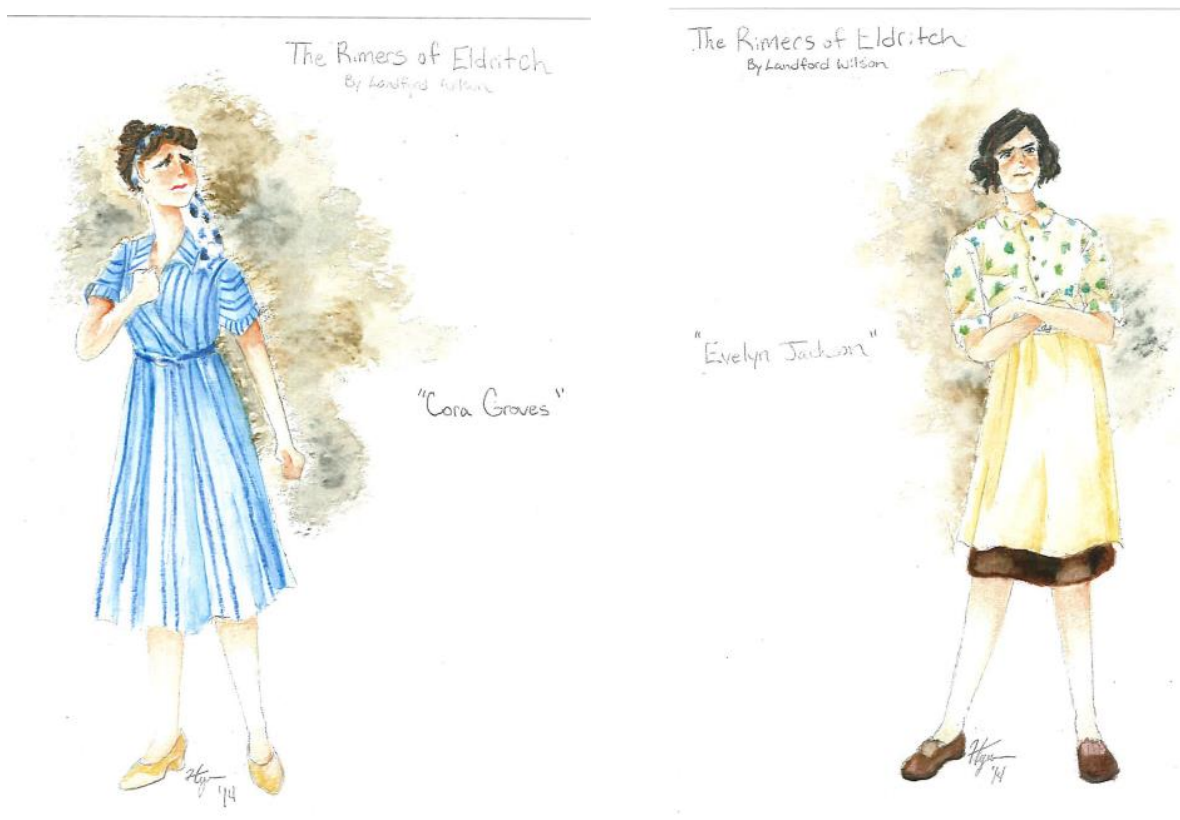

Sketches of Cora Groves and Evelyn Jackson

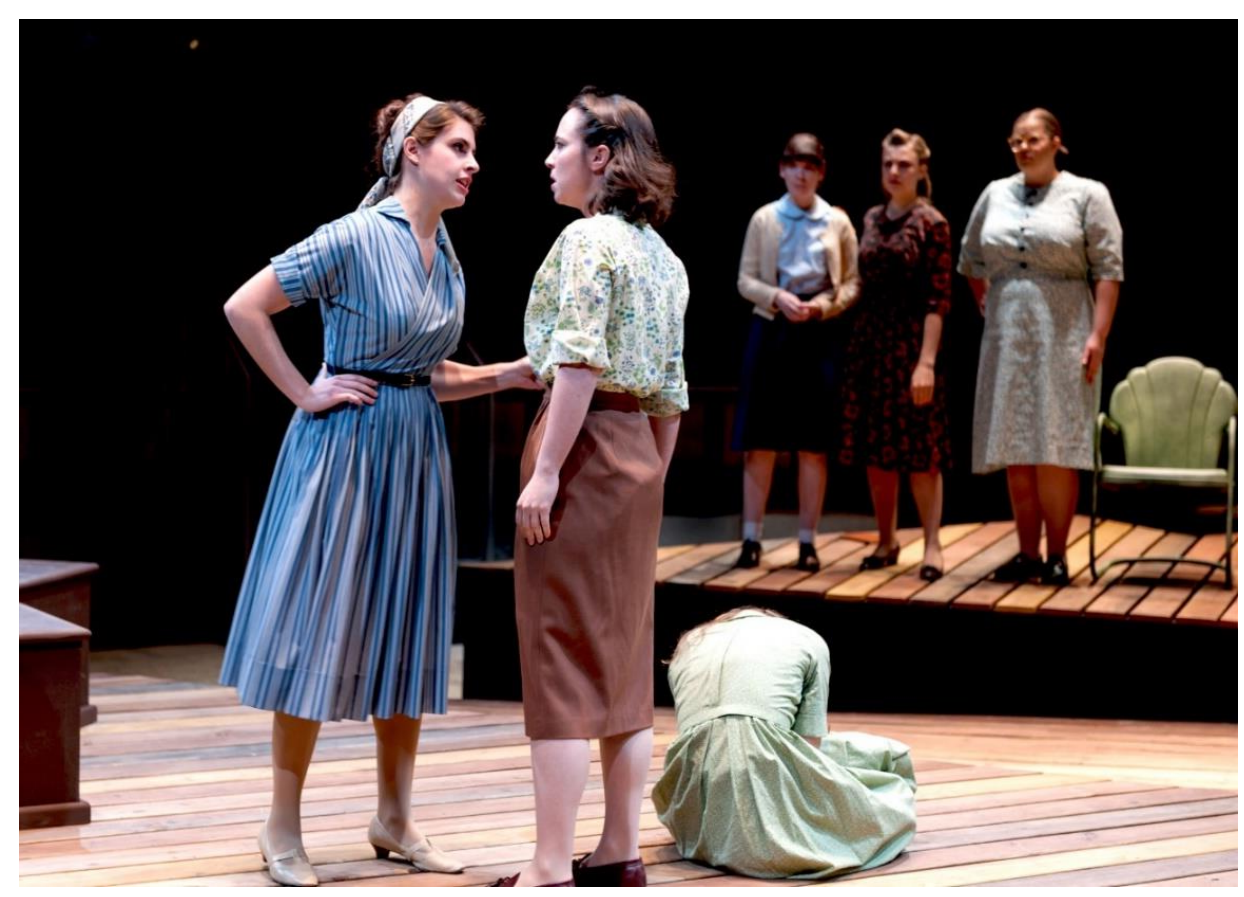

Production Photo taken by Michael Bailey

Figure 1.2: The Rimers of Eldritch sketches of Cora Groves (Left) and Evelyn Jackson (Right) and a production photo taken by Michael Bailey 


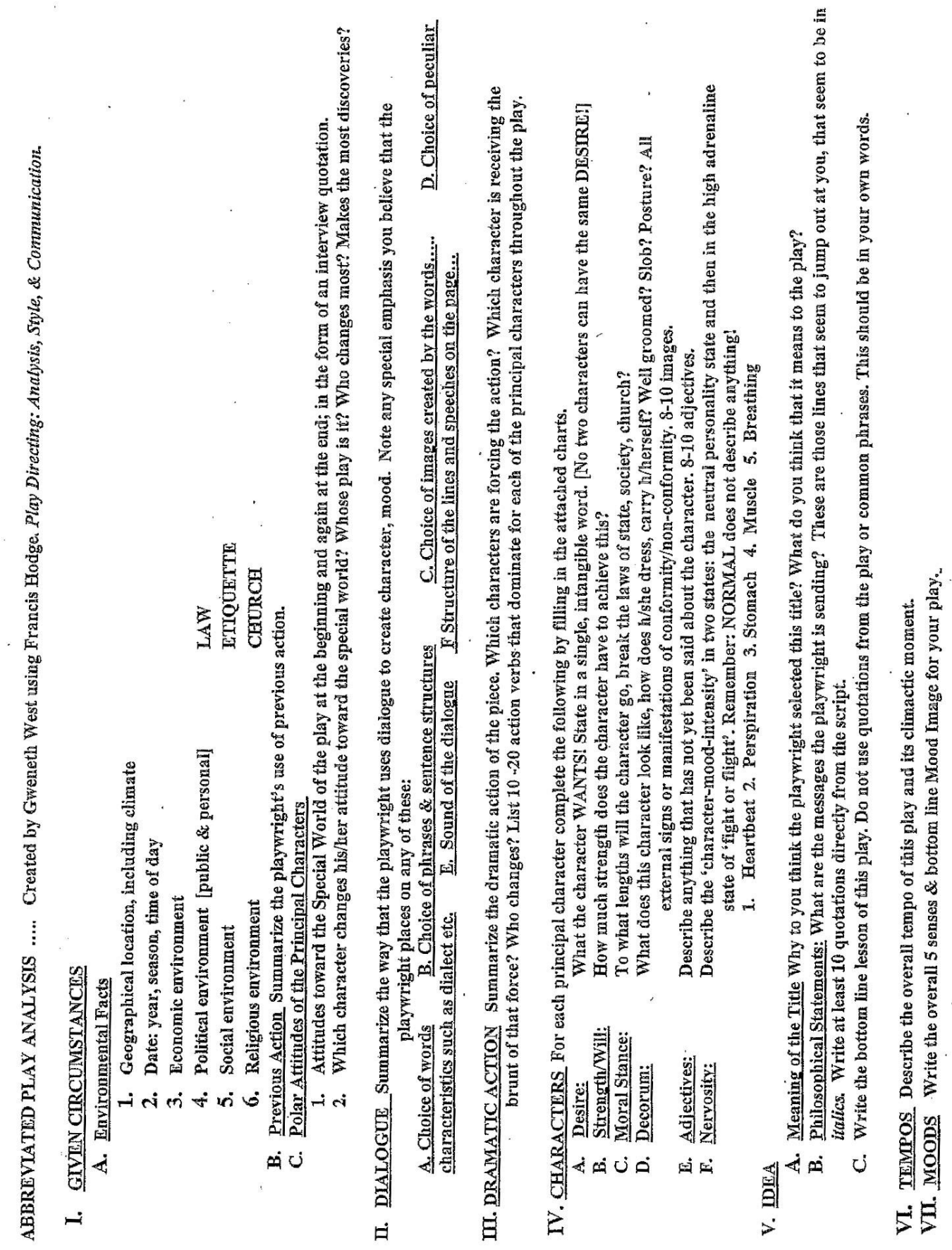

Figure 1.3: Copy of the abbreviated hodge analysis created by Professor Francis Hodge and adapted by Gweneth West 


\section{A Street Car Named Desire: Script Analysis}

\section{Given Circumstances}

A) Environmental facts

1. Geographical Location: New Orleans, Louisiana, USA. Humid, wet, and hot. Near the ocean. City. Cramped

2. Date: 1940 s. Takes place in the spring, summer, and fall, during different points of the day. Episodic.

3. Economic Environment: The building the Kovaliski live in is a two floor flat, in a poor but 'charming' neighborhood. Races intermingle in this part of town

4. Social environment: New Orleans was known as a 'melting pot" of races. Because of the new street car networks gave the inner city upper class the means to easily move in and out of the city. They left many nice town homes in the city. With all the immigrants and different types of music, jazz was born.

5. Political environment: With all the immigrants and different types of music, jazz was born. The amount of women in the work force increased by 25-30 percent. After WWII broke out, women had to step up and become more involved in the work force. 1945 Eleanor Roosevelt became a U.S. delegate for a newly established United Nations

6. Religious environment: Women were becoming more independent from the image of the housewife. There was a divide from the 'perfect lady' and the 'modern lady'. Men came back from the war, and women were expected to go back to being the perfect wife.

B) Previous Action: Williams uses this device to recount Blanche's past, and how she came to her be at Stella's apartment in New Orleans. She goes through many stories, which leaves Stanley suspicious to find the truth.

C) 1. Blanche: "I am searching for a helping hand."- beginning

"All people do is take from you."- Ending

Stella: "I'm in love with love." -Beginning

"I've had the idealistic glass shatter." -ending

Stanley: "I am the top dog." -Beginning

"I have lost control." -Ending

2. Stella's special world changes the most. Stella was living in her own dream world, but once Blanche is carted off to the asylum, Stella leaves this past image behind and knows that the real world is cruel.

The play is Blanche's. We follow her break down, and how she cant fit into the world, and how that destroys her.

Figure 1.4 (A): A Streetcar Named Desire abbreviated analysis page one, showing the given circumstance 


\section{Dialogue}

A.) choice of words: Blanche is stuck in her past, still speaking as a southern belle while Stella is drawing away from it.

B.) Choice of phrases and sentence structures: Blanche was a English teacher, so her sentences are full of rich words and perfect grammar. Stanley speaks with less intelligence. His sentences come off choppy.

C.) Choice of images created by the word: Blanche paints many fantastical images with her stories, blurring the lines between reality and fantasy.

E.) Sounds of the dialogue: The flow is very structured and realistic. The pace is fast and gives off tensions, especially with Blanch and Stanley. There words seem to fall over one another.

\section{Dramatic Action}

-Blanche moving into Stella and Stanley's apartment for and unknown amount of time. Blanche forces the action. Stanley suffers the most with her being their, because she challenges his intelligence and power as a man. Stella is the one who changes by the end of the play, Stanley and Blanche learning nothing from one another.

Blanche: Preform, Acquire, Adapted, Discover, recede, shield, compose, improve, restore

Stanley: Confront, model, manage, perceive, protect, instigate, teach,

IV. Ideas overpower, target

A) Meaning of the title: Streetcars were a big form of transportation in New Orleans at the time. I believe the title incorporates that and the word 'desire; is pointed to Blanche- it was the name of the train that brought her but it also symbolizes that she desires so much. And that she brings a type of desire out to others she encounters

B) Philosophical Statements:

\section{Men's Masculinity and Women's Repression}

1)Stella: "You come out with me while Blanche is getting dressed."

Stanley: "Since when do you give me orders?"

2)Stella: "Stanley doesn't give me a regular allowance/ He likes to pay the bills himself"

Sex and the control/violence it has on society (example: The Rape)

3)Stella: "Why on our wedding night, soon as we came in here- he snatched

off my slippers and rushed about the place smashing light bulbs

Blanche: "And you let him? Didn't run? Didn't scream?"

Stella: "I was- sort of- thrilled by it."

4) Blanche: "What you are talking about is brutal desire- just- Desire! The name of that rattle trap street car that bans through the Quarter, up old Narrow Street and down the other."

Figure 1.4 (B): A Streetcar Named Desire abbreviated analysis page two, showing dialogue, dramatic action, and ideas 
5) Stanley: "We've had this date with each other from the beginning."

6) Blanche "I just want to be near you, got to be with somebody because I can't be alone!"

\section{Tempos}

- The all over tempo of this play is fast yet tense, the tension building along with the "Blue Piano" music. The climatic moment in the scene is where Stanley rapes Blanche.

\section{Moods}

Smell. Smog ,spices, salty

Taste. Salt, dry, hot

Touch. Sweaty, static shocks

Sight: bright blurs of color through a smog

Sound: Bass drum with a lone saxophone

Mood: Tragic, somber, electric

\begin{tabular}{|c|c|c|c|c|}
\hline IV. CHARACTERS 1 & Blanche & Stella & Stanley & Mitch \\
\hline DESIRE [1 WORD] & Companionship & intamaciy & Contral & Stability \\
\hline W!LL / STRENGTH & weaving a tail. & Sex/companion & $\begin{array}{l}\text { wocking Man / } \\
\text { money peovider }\end{array}$ & \\
\hline MORAL STANCE & $\begin{array}{l}\text { Pleasuce leads } \\
\text { to happiness }\end{array}$ & Doteful Wife & Husband leads & \\
\hline DECORUM [8-10] & $\begin{array}{l}\text { - Daesses in the } \\
\text { Best clothes } \\
\text { - evey acticie of } \\
\text { cloting has a st-ay } \\
\text { - haic in fashisa } \\
\text { - accessies } \\
\text { - Pecfect postuce }\end{array}$ & $\begin{array}{l}\text { - hot up to style } \\
\text { - goo d pootuce } \\
\text { - cleam bet simple } \\
\text { - veciess wher can } \\
\text { be affer tes } \\
\text { - still pemi fushonible } \\
\text { - bolls up for huoldand }\end{array}$ & 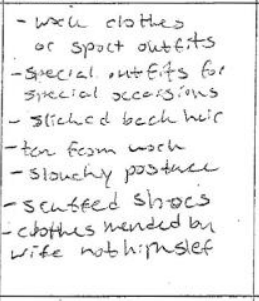 & . \\
\hline ADJECTIVES $[8-10]$ & $\begin{array}{l}\text { - cceative } \\
\text { - lovely } \\
\text { - caring } \\
\text { - aichended } \\
\text { - shelfish } \\
\text { - sistecly } \\
\text { - fagile } \\
\text { - seccetive }\end{array}$ & $\begin{array}{l}\text { - motheoly } \\
\text { - affect oncte } \\
\text { - simple minided } \\
\text { - focgiving } \\
\text { - fostish } \\
\text { - trusting } \\
\text { - ighocaut } \\
\text { - timid }\end{array}$ & $\begin{array}{l}\text { - bcash } \\
\text { - lond } \\
\text { - steong } \\
\text { - stwbloon } \\
\text { - defensive } \\
\text { - insecuce } \\
\text { - loving } \\
\text { - devsted. }\end{array}$ & . \\
\hline
\end{tabular}

Figure 1.4 (C): A Streetcar Named Desire abbreviated analysis page three showing moods and tempo and the character chart 


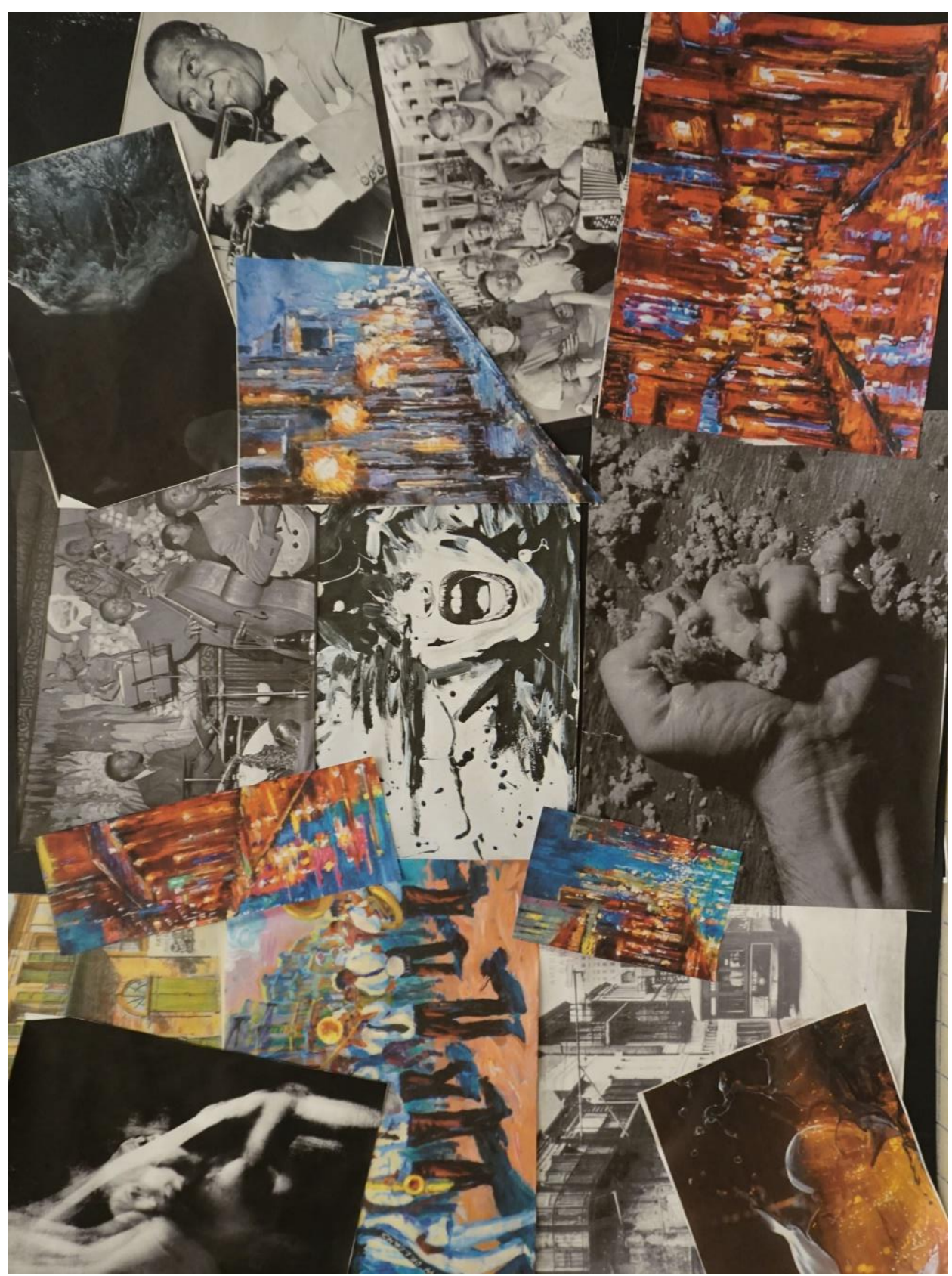

Figure 1.5: A Streetcar Named Desire special world board, showing the vibrant New Orleans, streetcars, and 'The Scream' in the middle of the board 

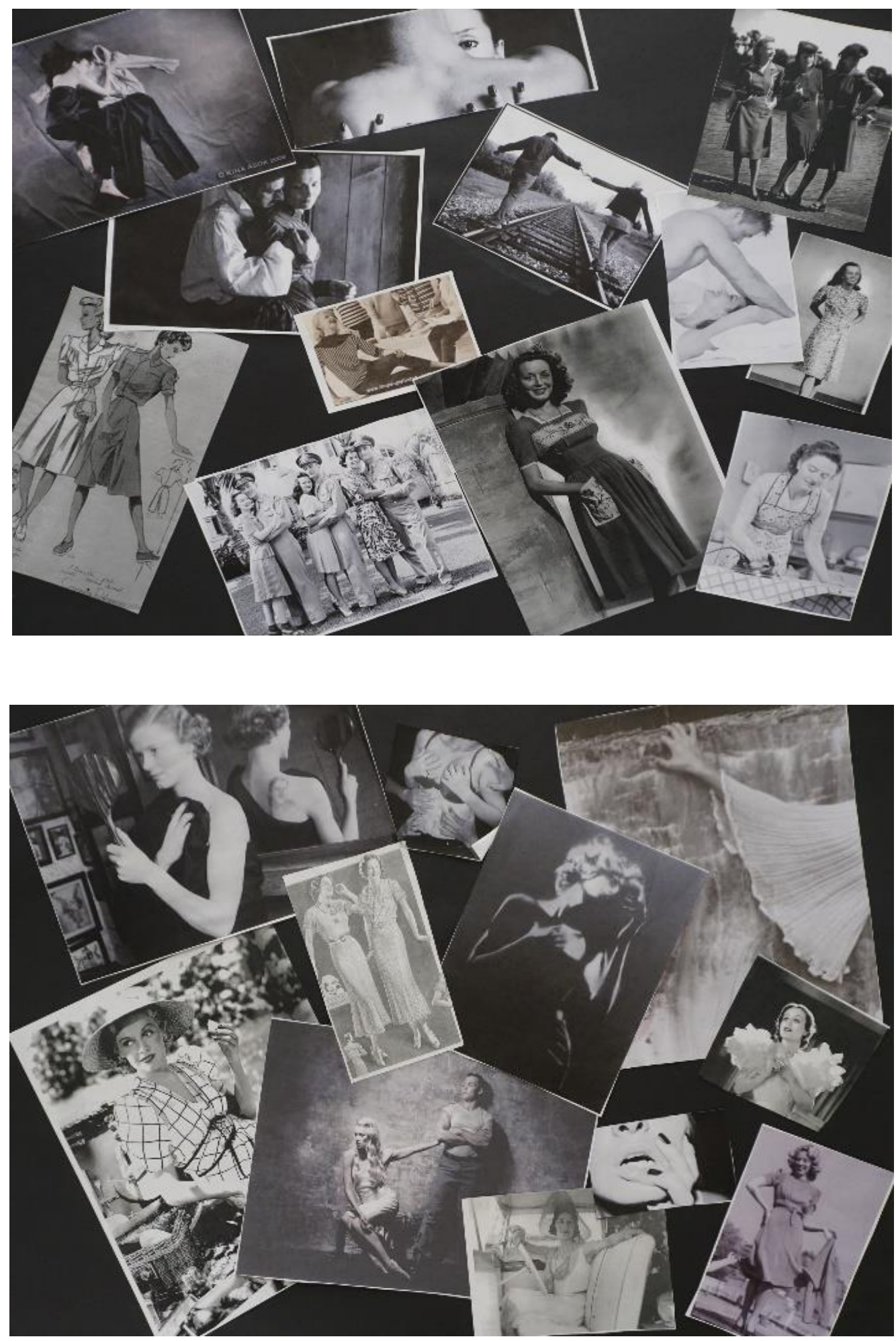

Figure 1.6: A Streetcar Named Desire character board of Stella (Top) and Blanche (Bottom) 
Appendix Chapter 1
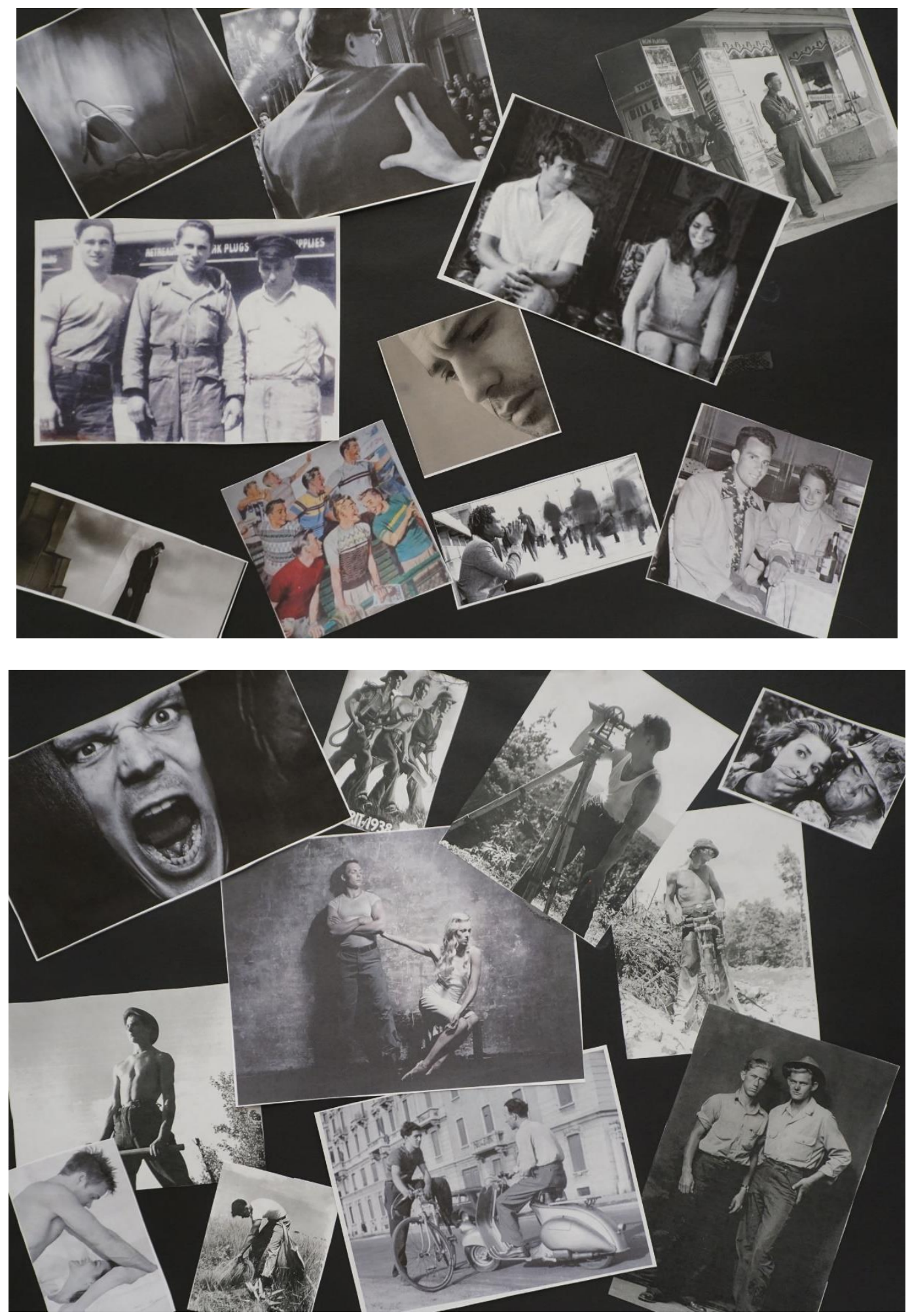

Figure 1.7: A Streetcar Named Desire character board of Mitch (Top) and Stanley (Bottom) 


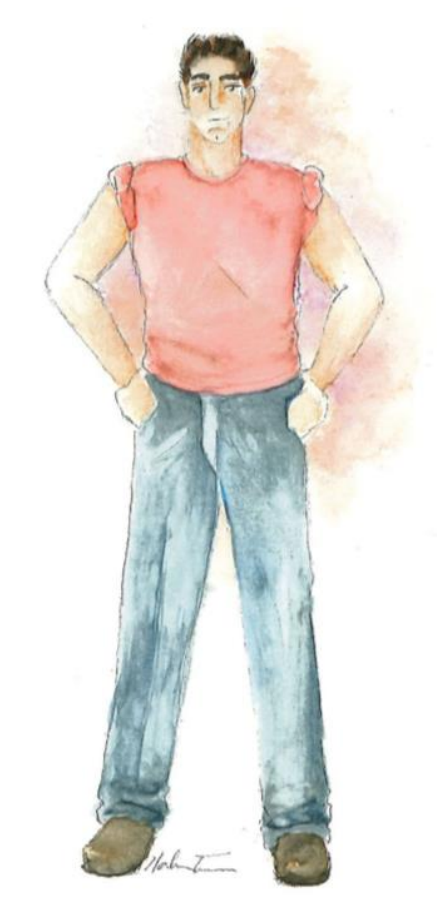

Stanley: Scene One
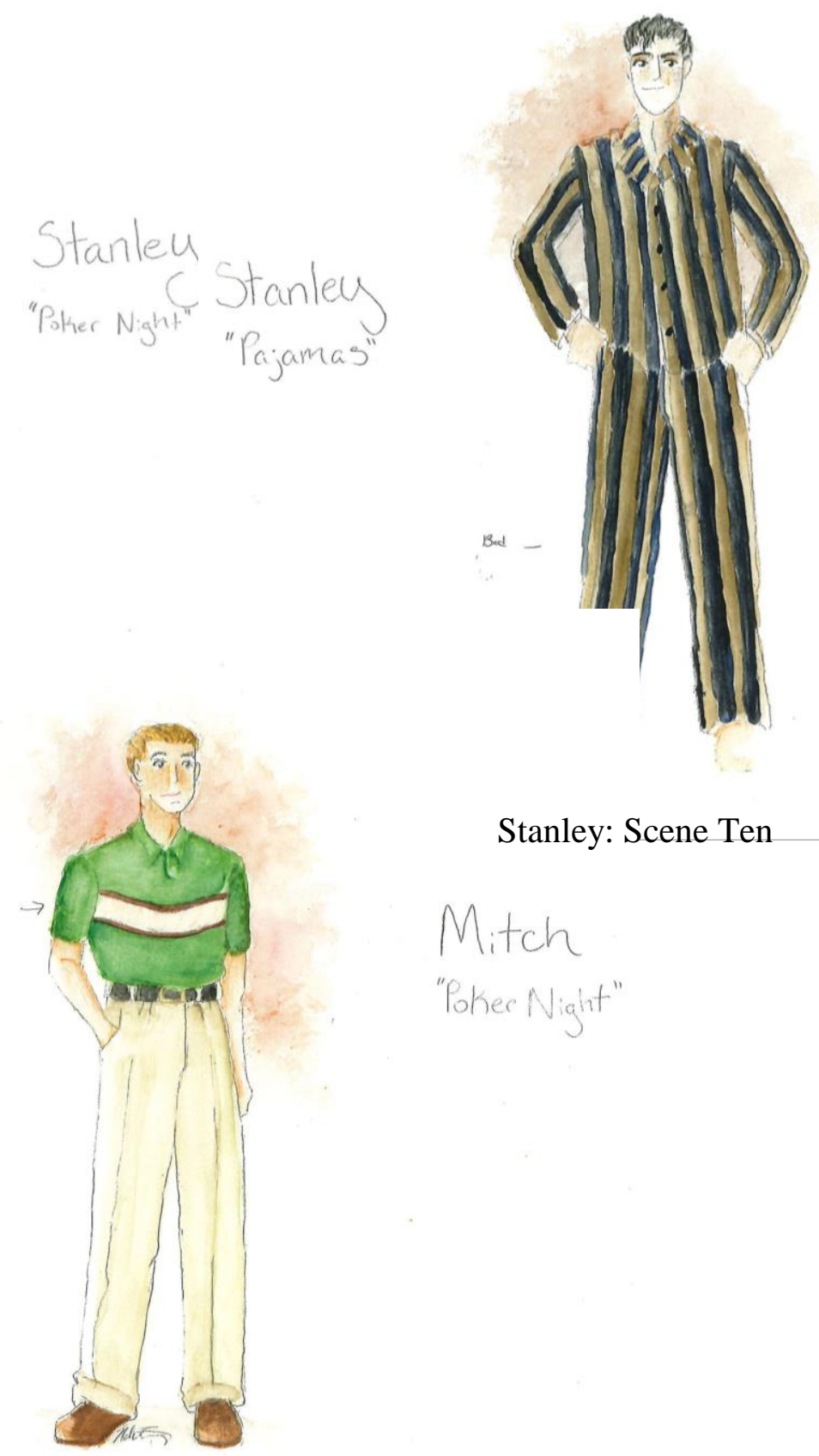

Stanley: Scene Ten

Mitch

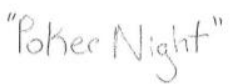

Mitch: Scene Three

Figure 1.8: A Streetcar Named Desire color sketches of Stanley (Top) and Mitch (Bottom) 


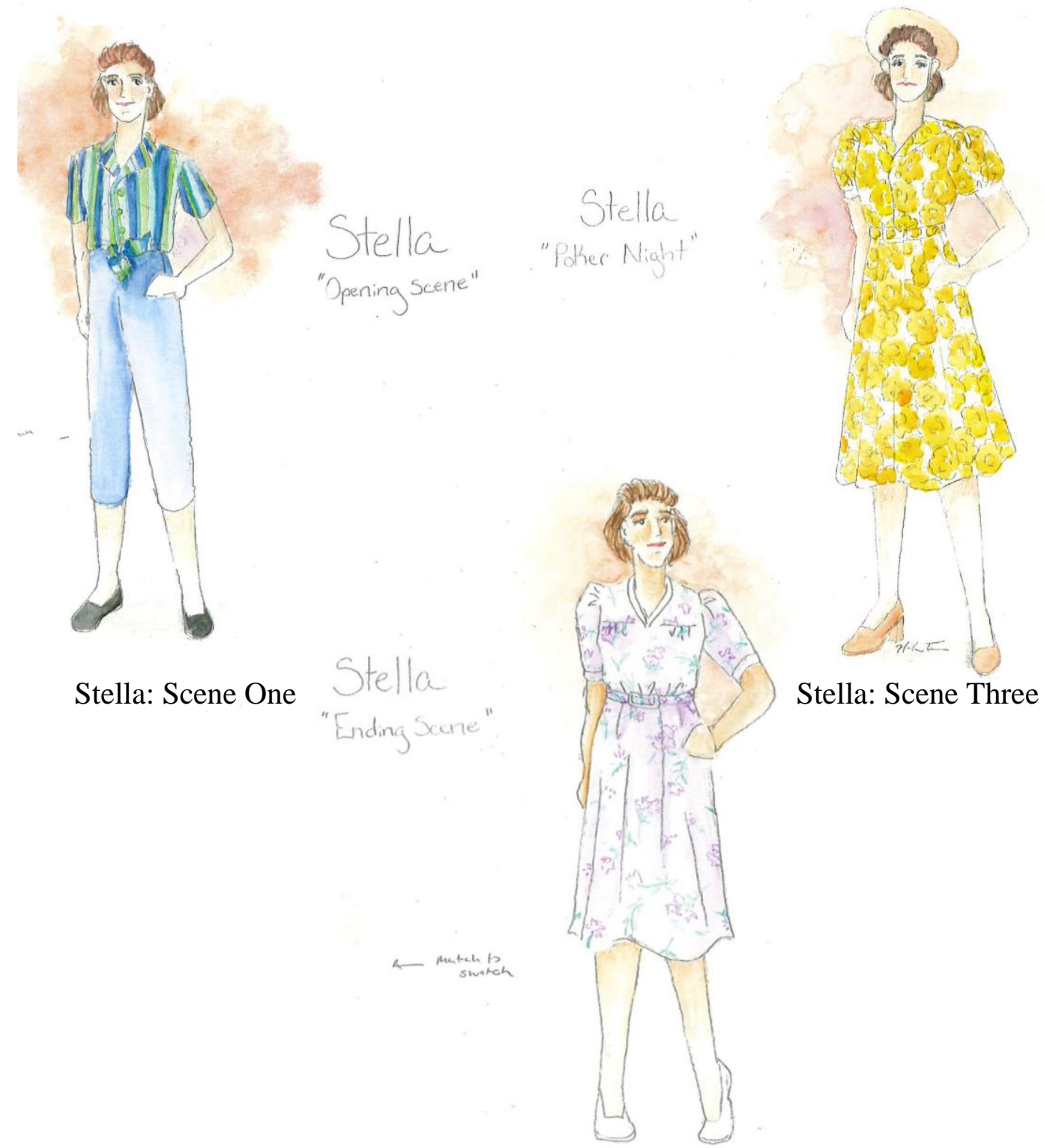

Stella: Scene Eleven

Figure 1.9: A Streetcar Named Desire color sketches of Stella 

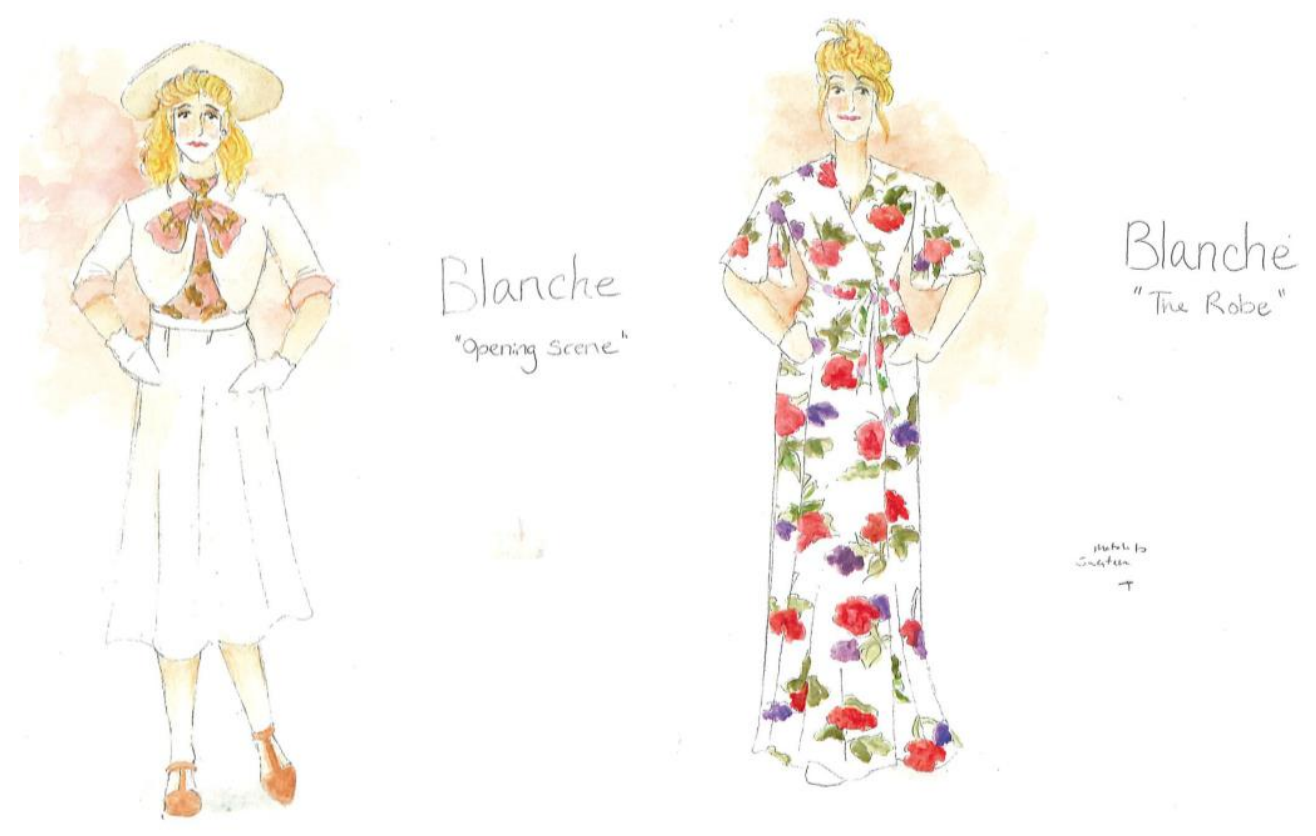

Blanche: Scene One

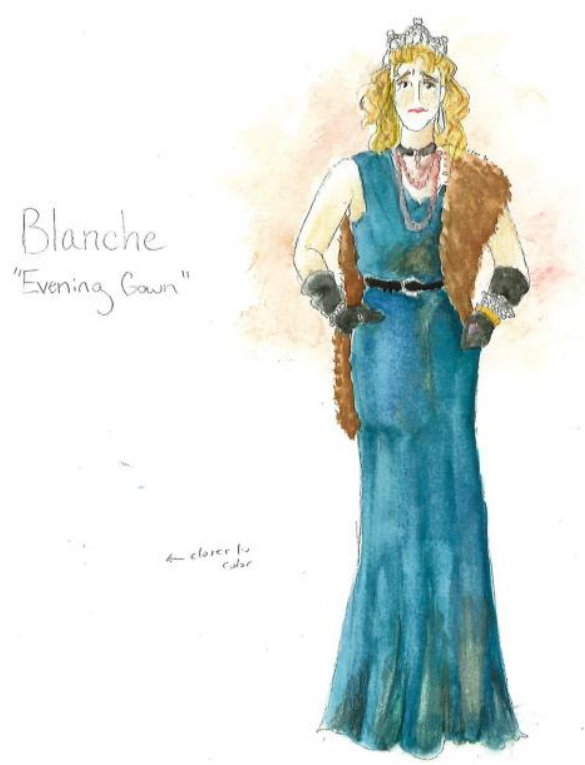

Blanche: Scene Three

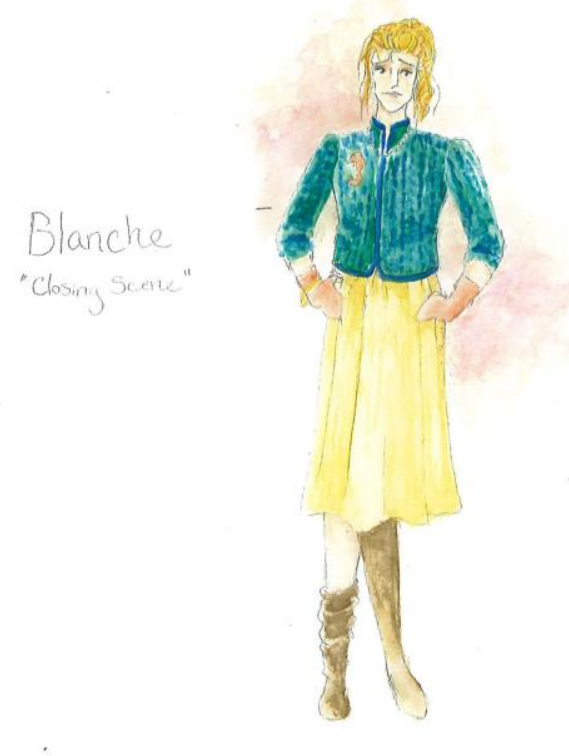

Blanche: Scene Ten

Blanche: Scene Eleven

Figure 1.10: A Streetcar Named Desire color sketches of Blanche 

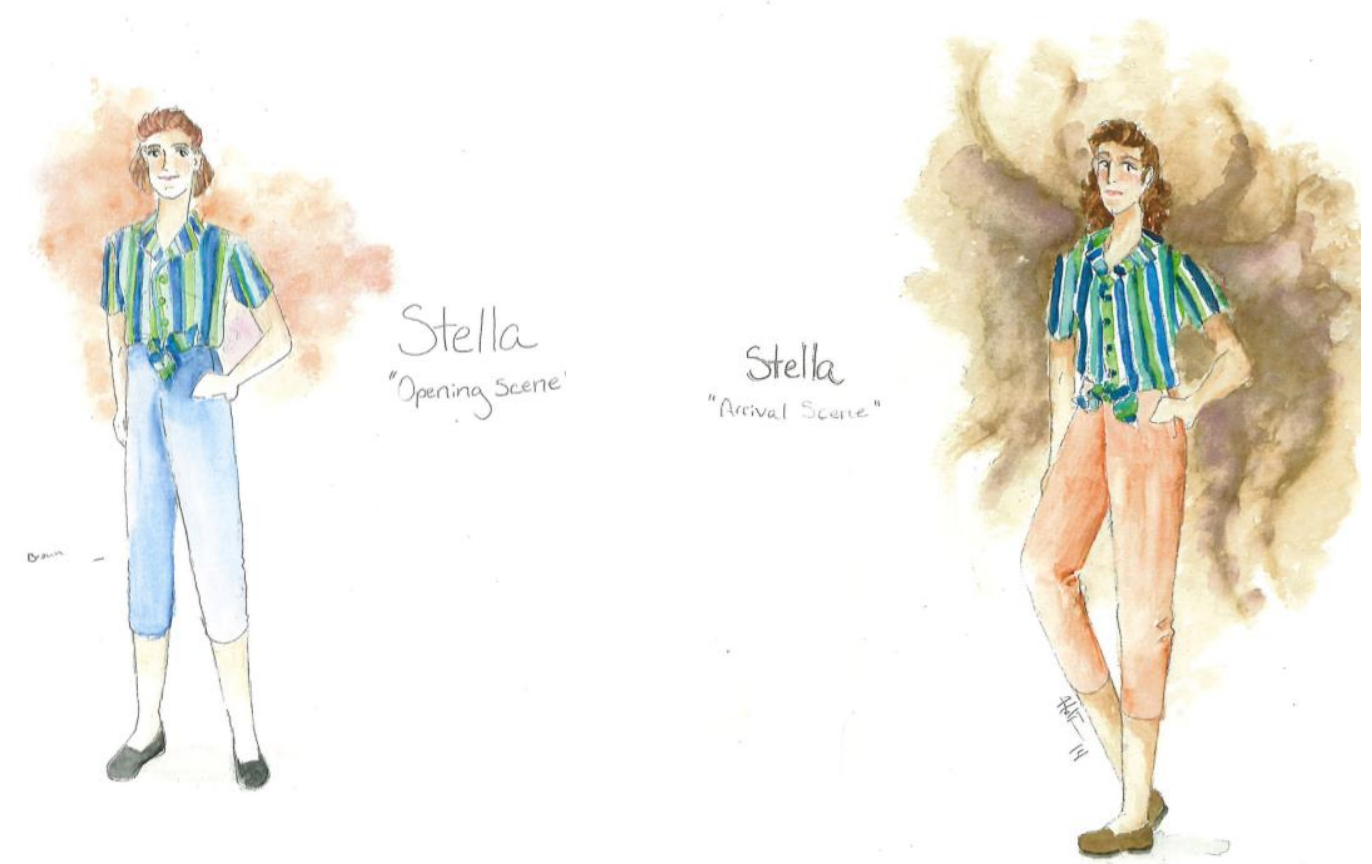

Stella: Scene One Original and the Revision
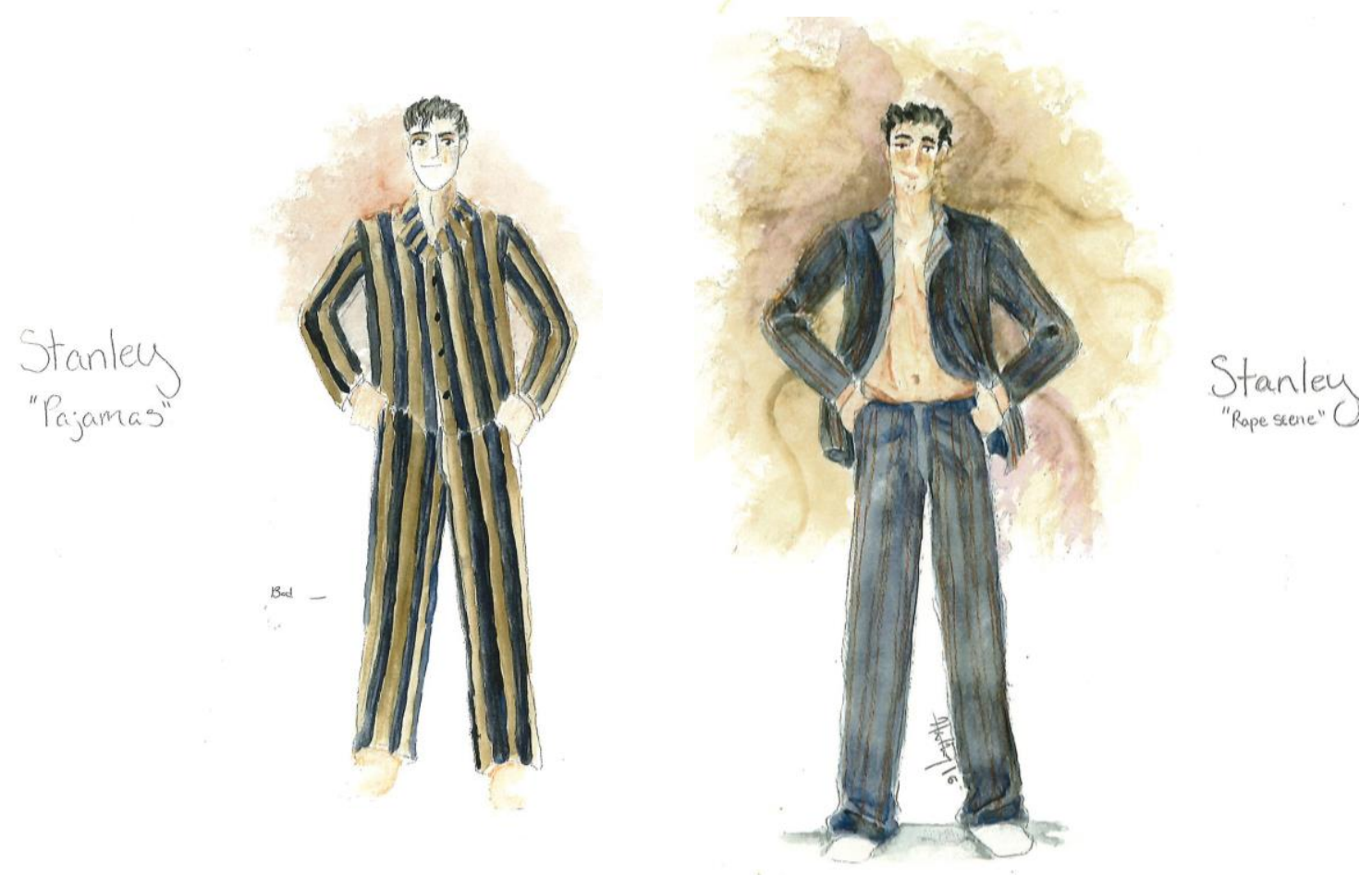

Stanley: Scene Ten Original and Revision

Figure 1.11: A Streetcar Named Desire original color sketches matched with their revisions 


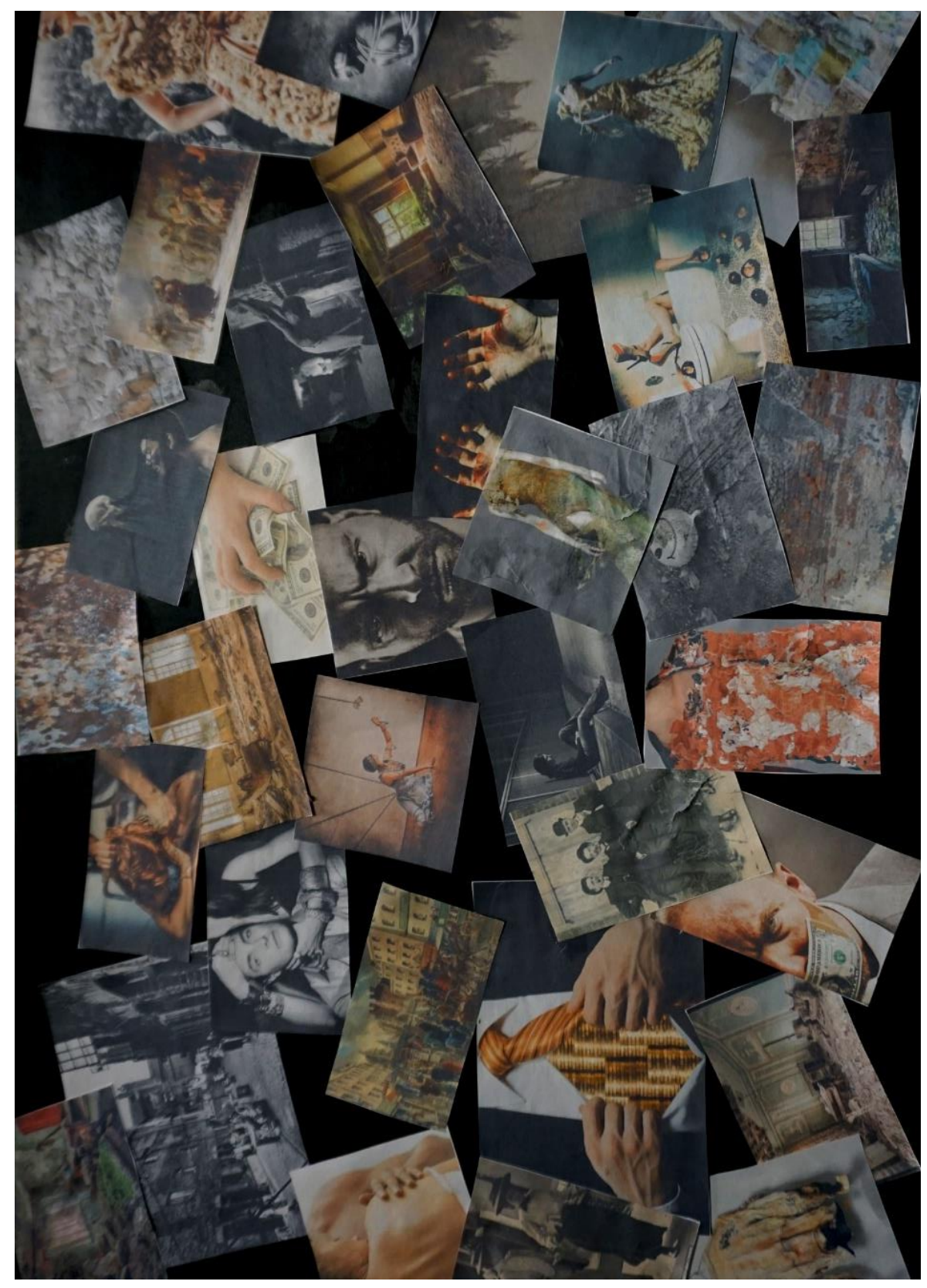

Figure 1.12: The Threepenny Opera special world board featuring pictures of different types of decay, greed, violence, and some period research 


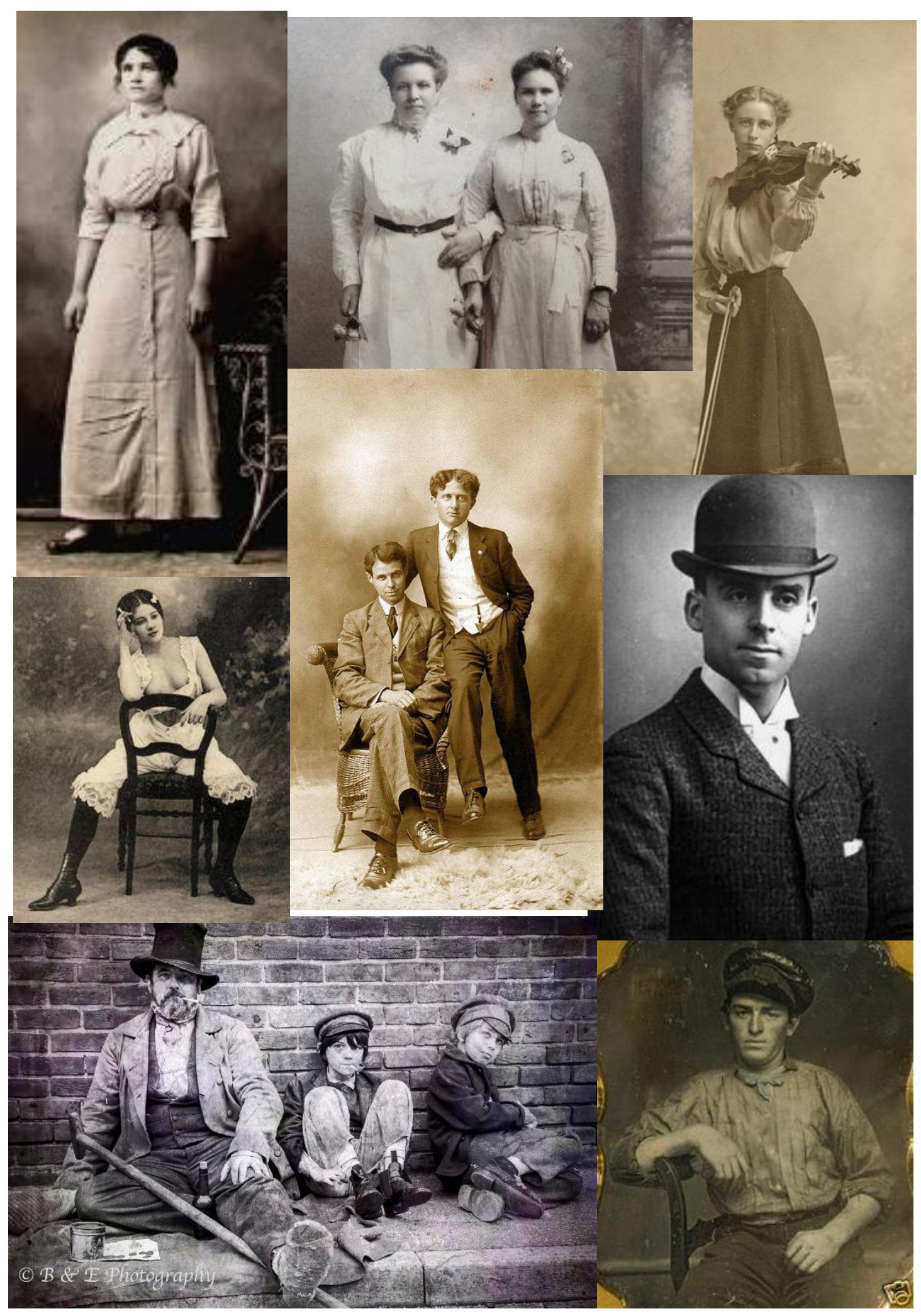

Figure 1.13: The Threepenny Opera research pictures 
The Three penny Opera

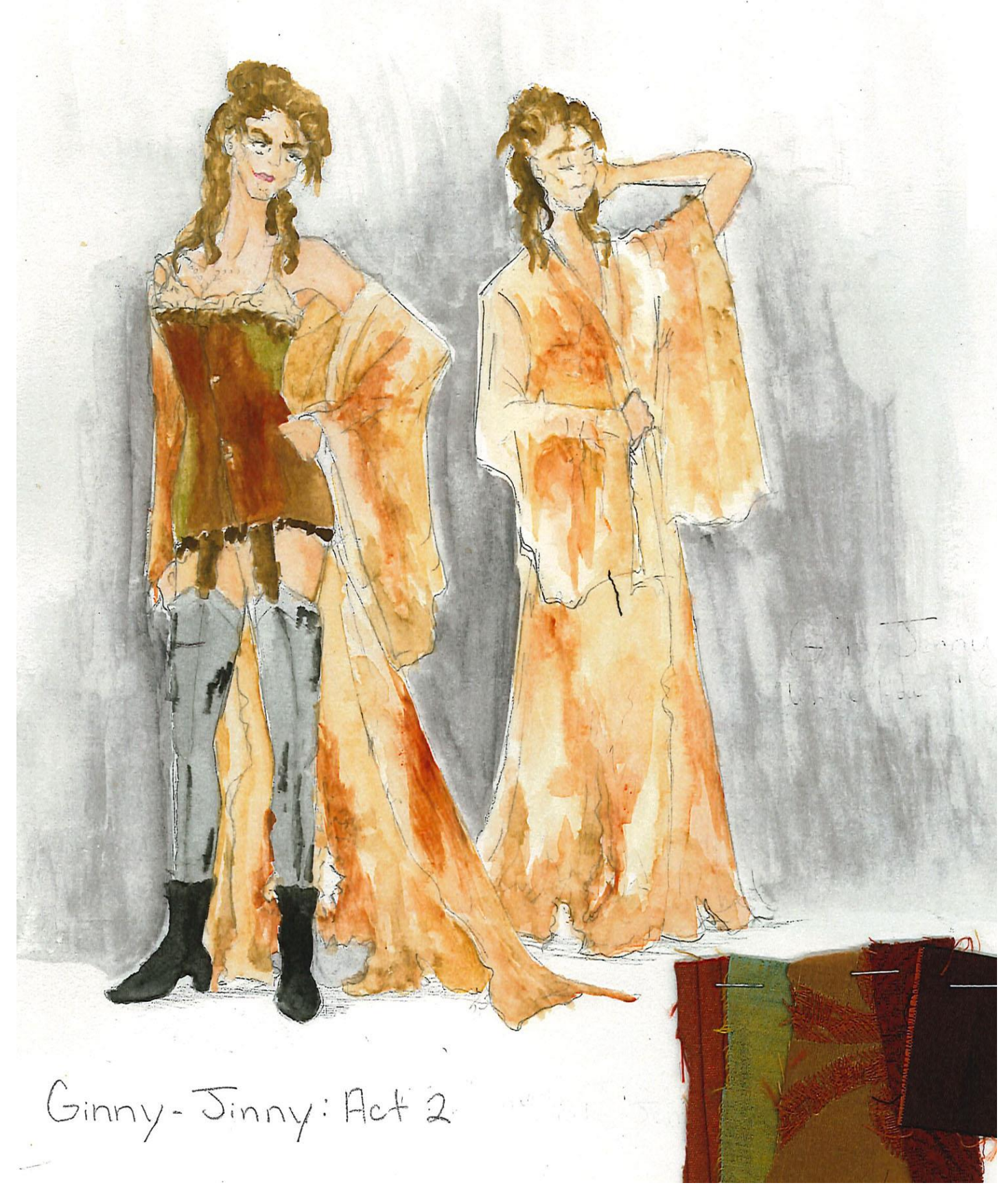

Figure 1.14: The Threepenny Opera color sketch of Ginny- Jenny Act two color sketch 

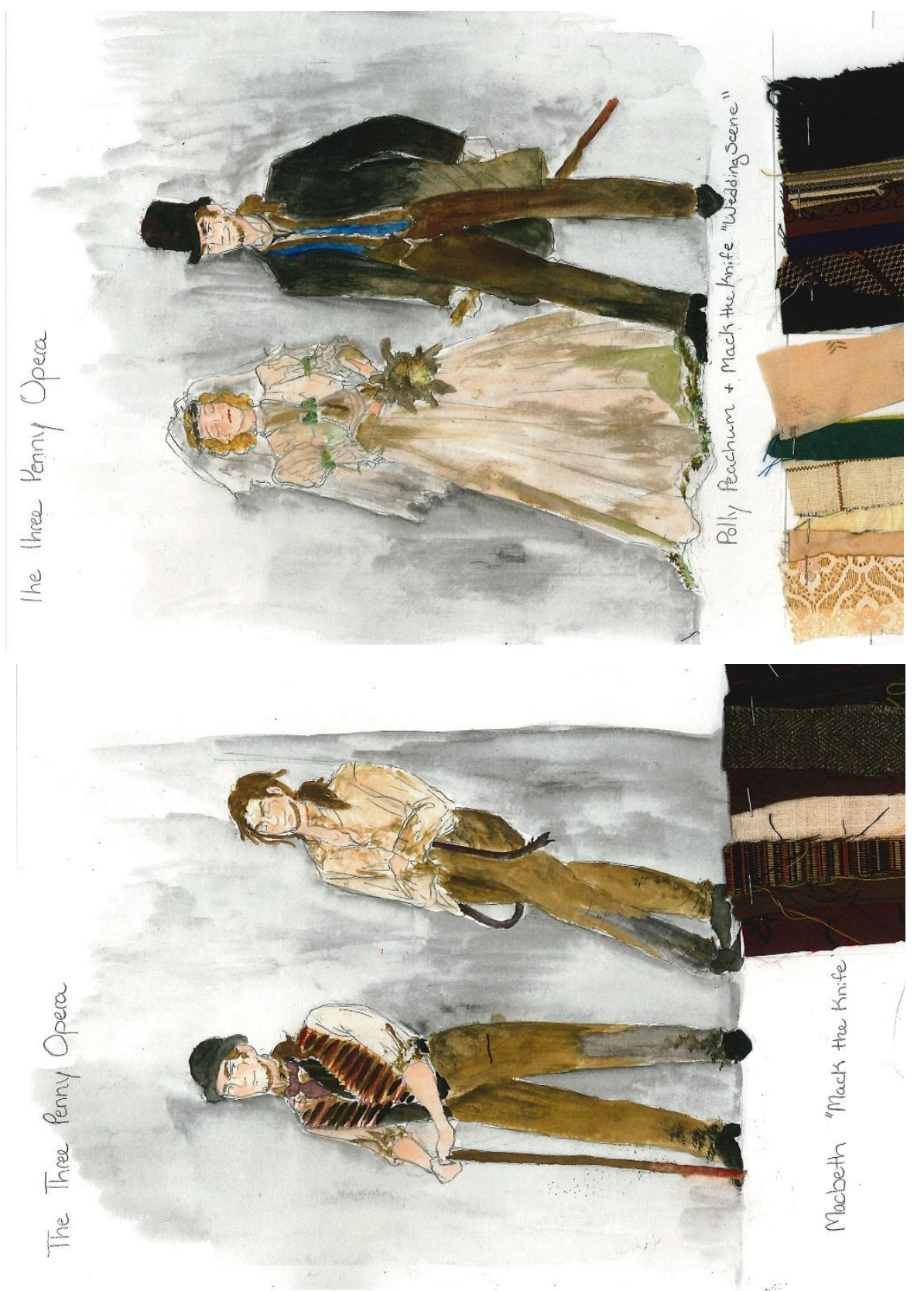

Figure 1.15: The Threepenny Opera color sketches of Mack the Knife, Act One through Act Three and Wedding with Polly Peachum 


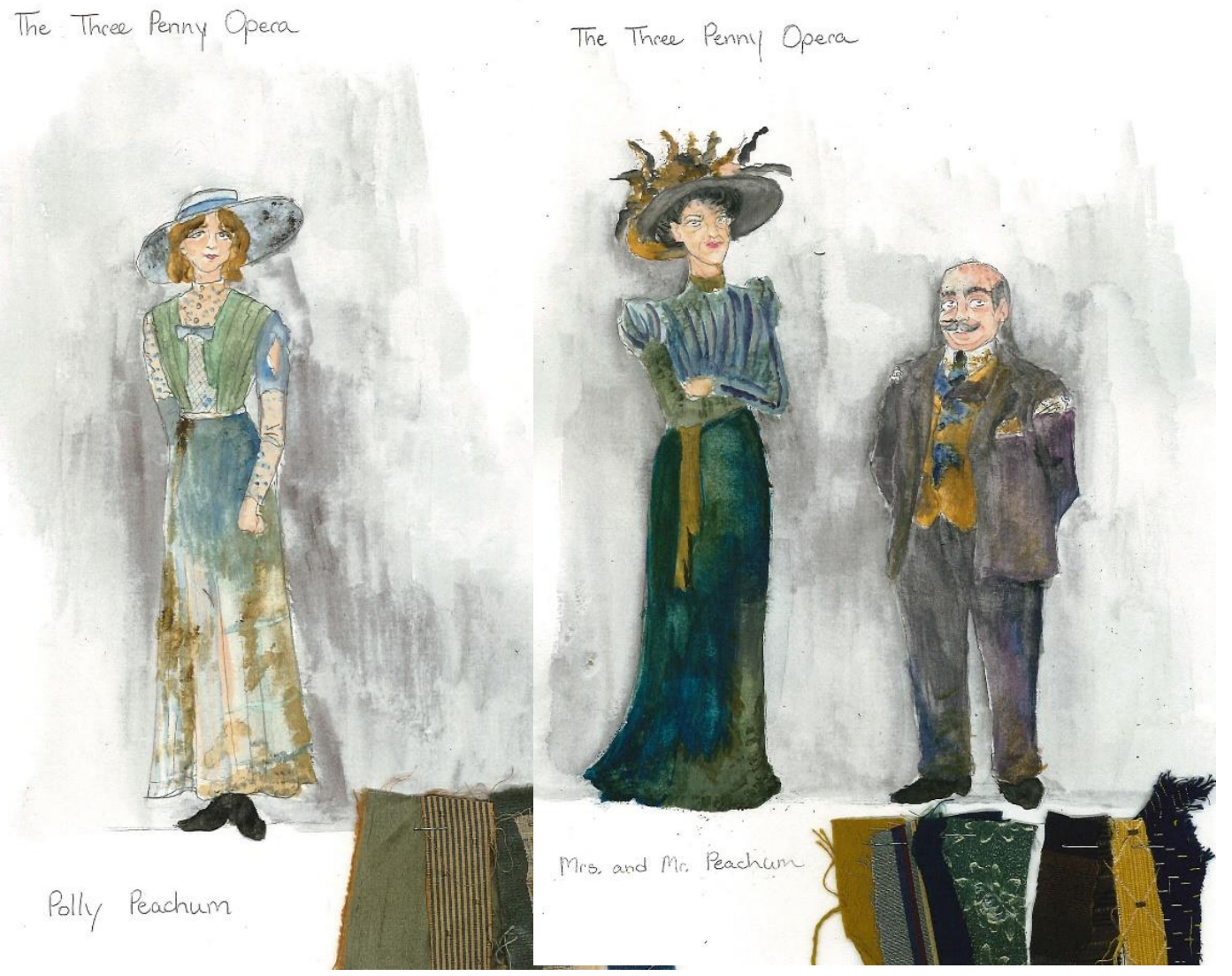

Figure 1.16: The Threepenny Opera color sketches Polly and Mr. and Mrs. Peachums'

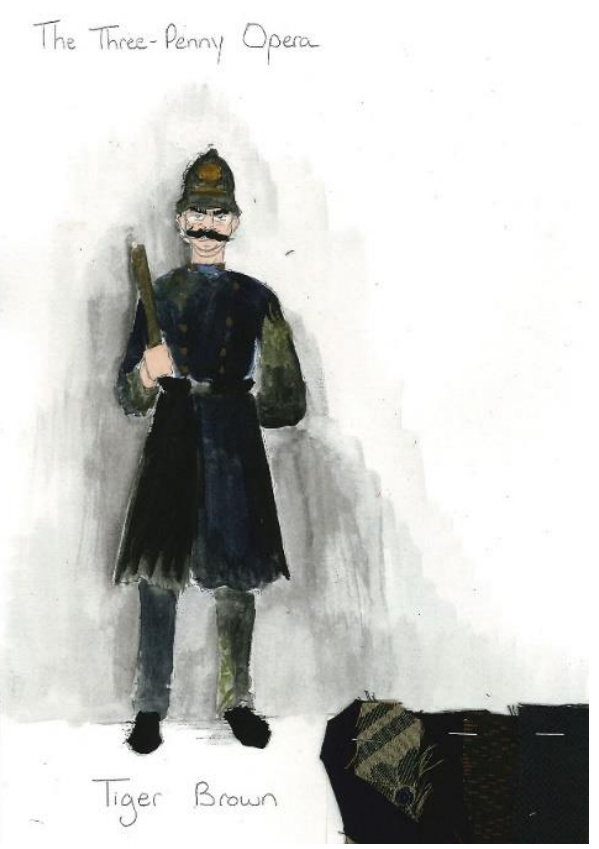

Figure 1.17: The Threepenny Opera color sketches Tiger Brown 


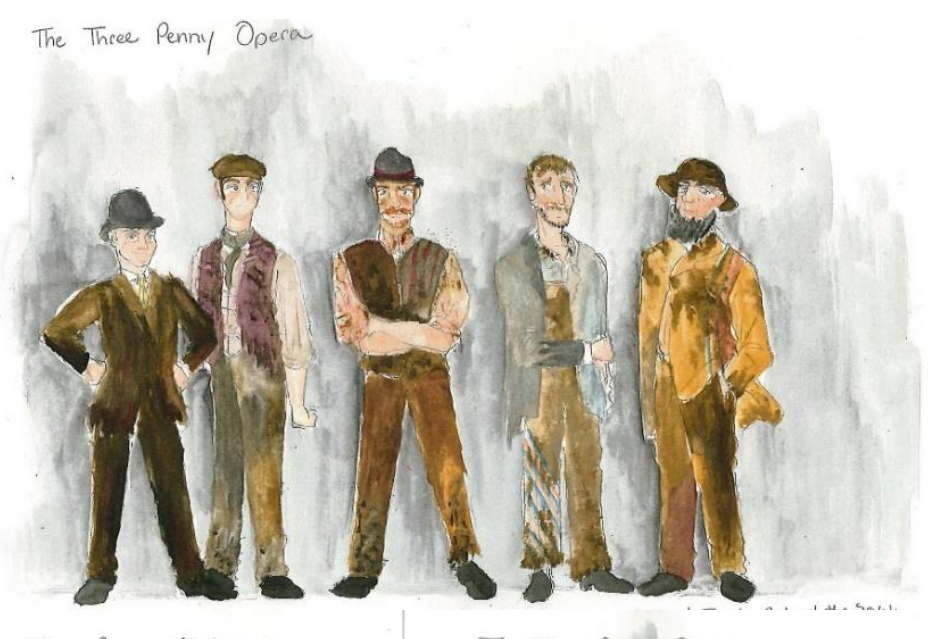

The Gang Members

The Gang Members
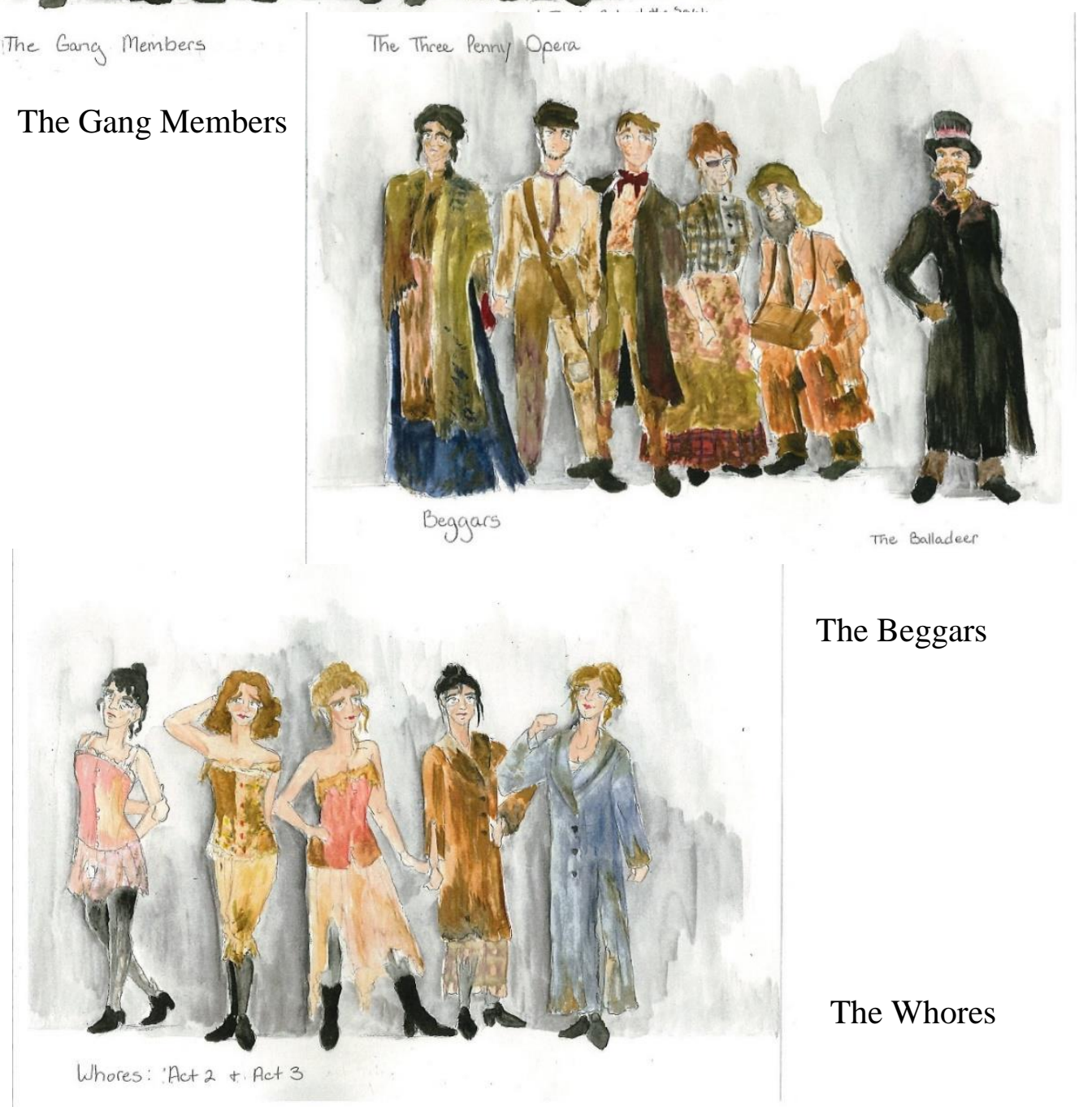

The Beggars

The Whores

Figure 1.18: The Threepenny Opera Group Plates of the Gang Members, the Beggars, and the Whores 


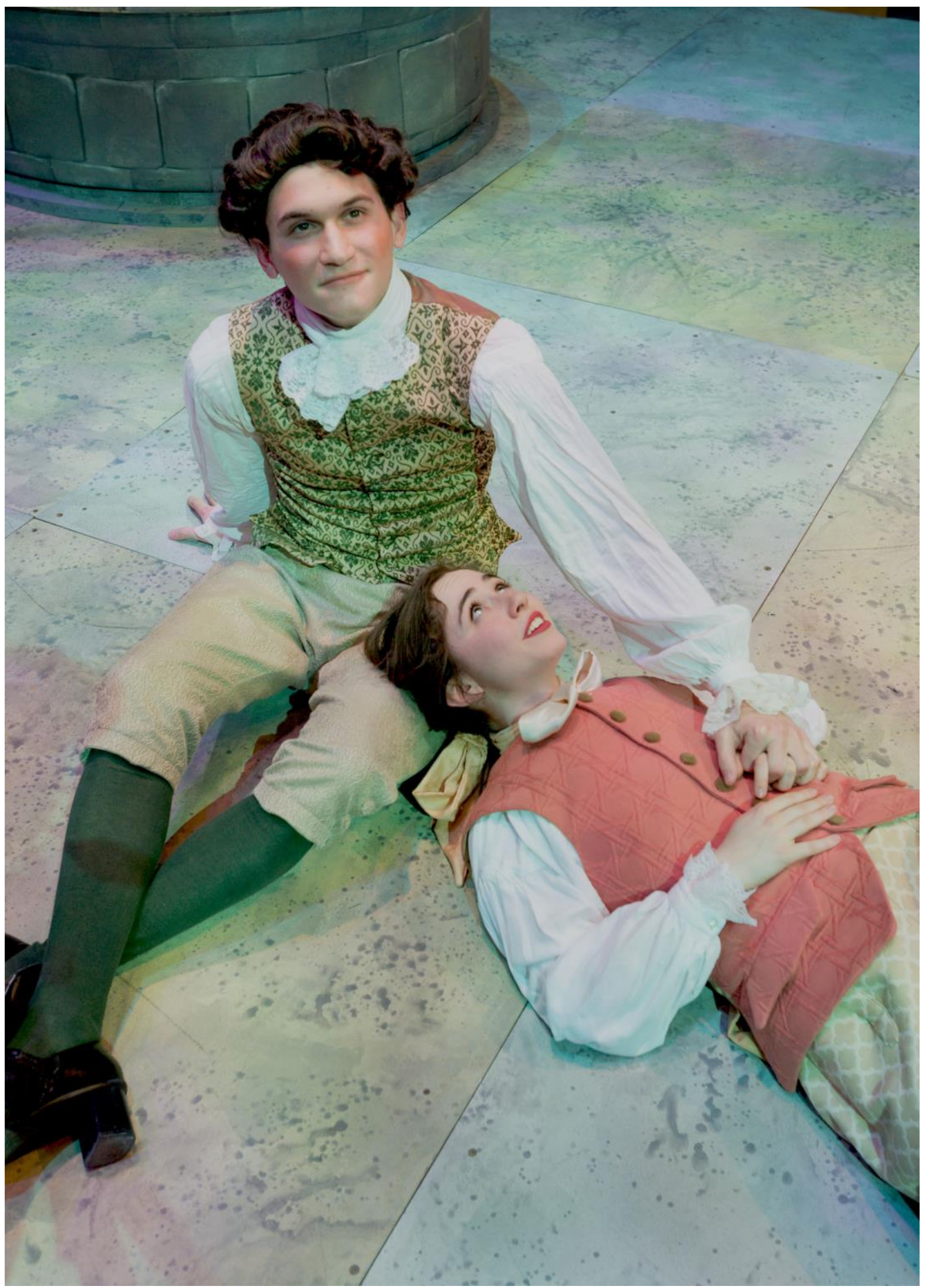

Figure 2.1: The Triumph of Love, taken by Michael Bailey, featuring the young lovers. From left to right is Agis and Léonide 
Appendix Chapter 2
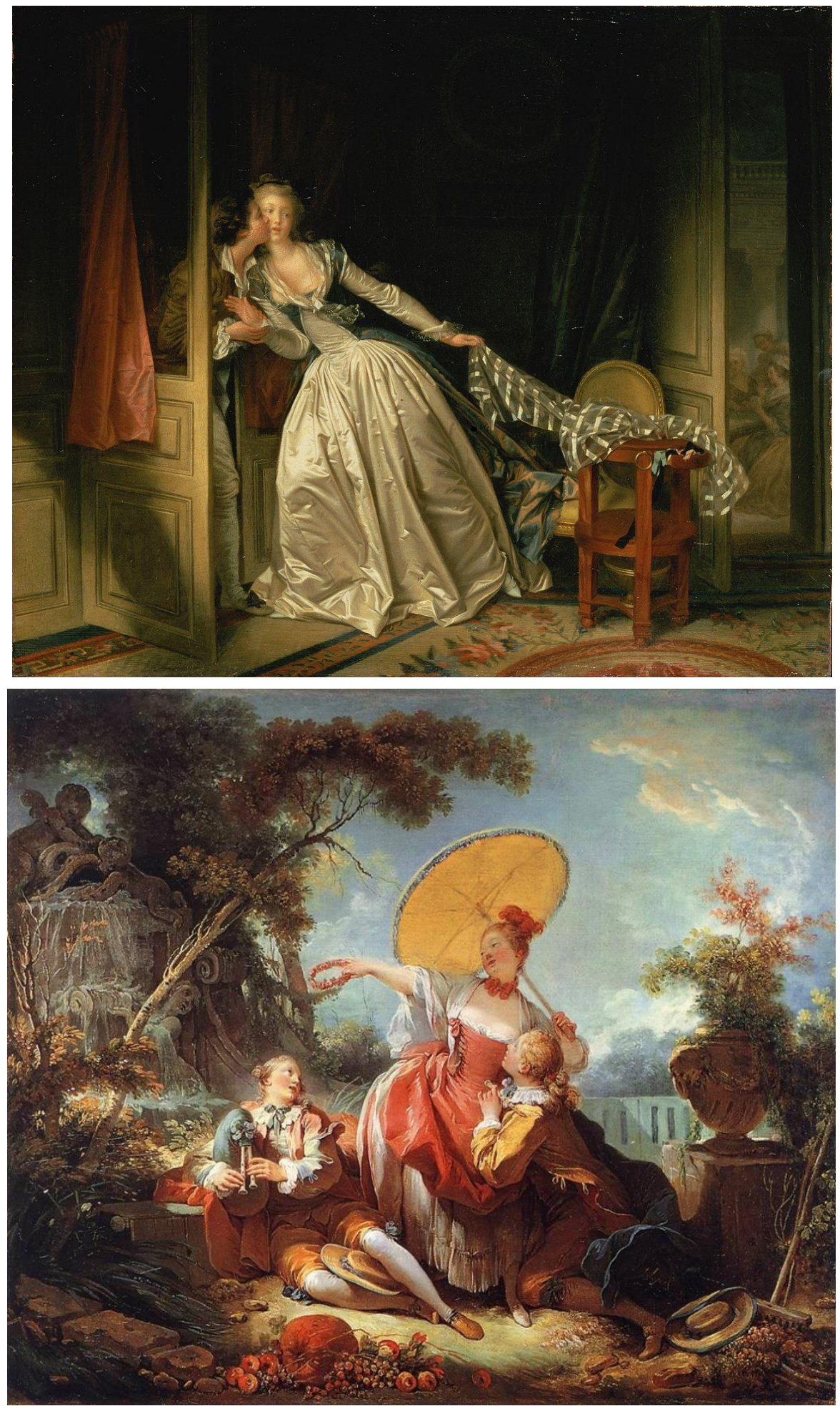

Figure 2.2: Inspiration from Jean-Honoré Fragonard paintings. (Top) The Stolen Kiss and (Bottom) The Singing Contest 


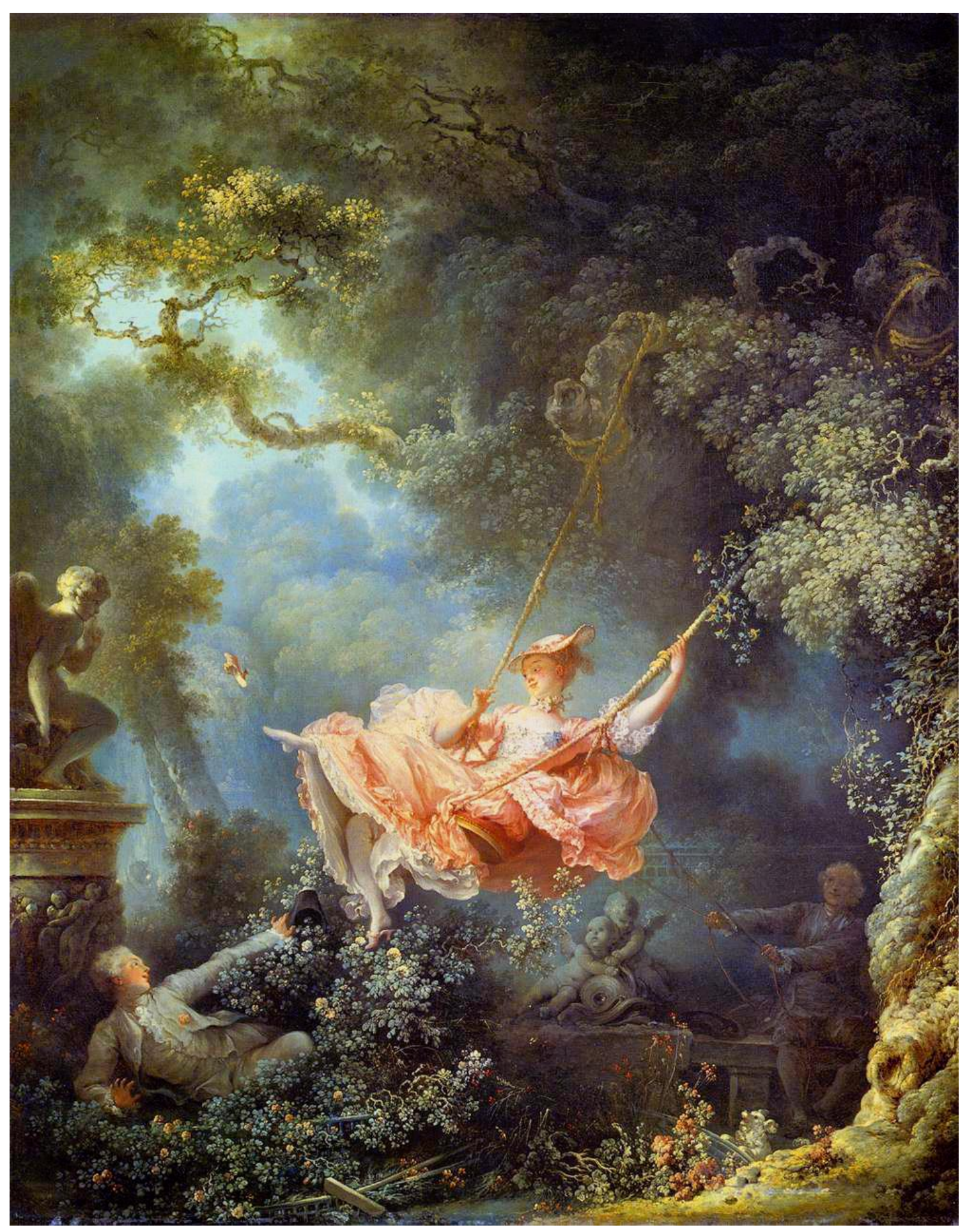

Figure 2.3: The Swing by Jean Honoré Fragonard, my main inspiration painting 


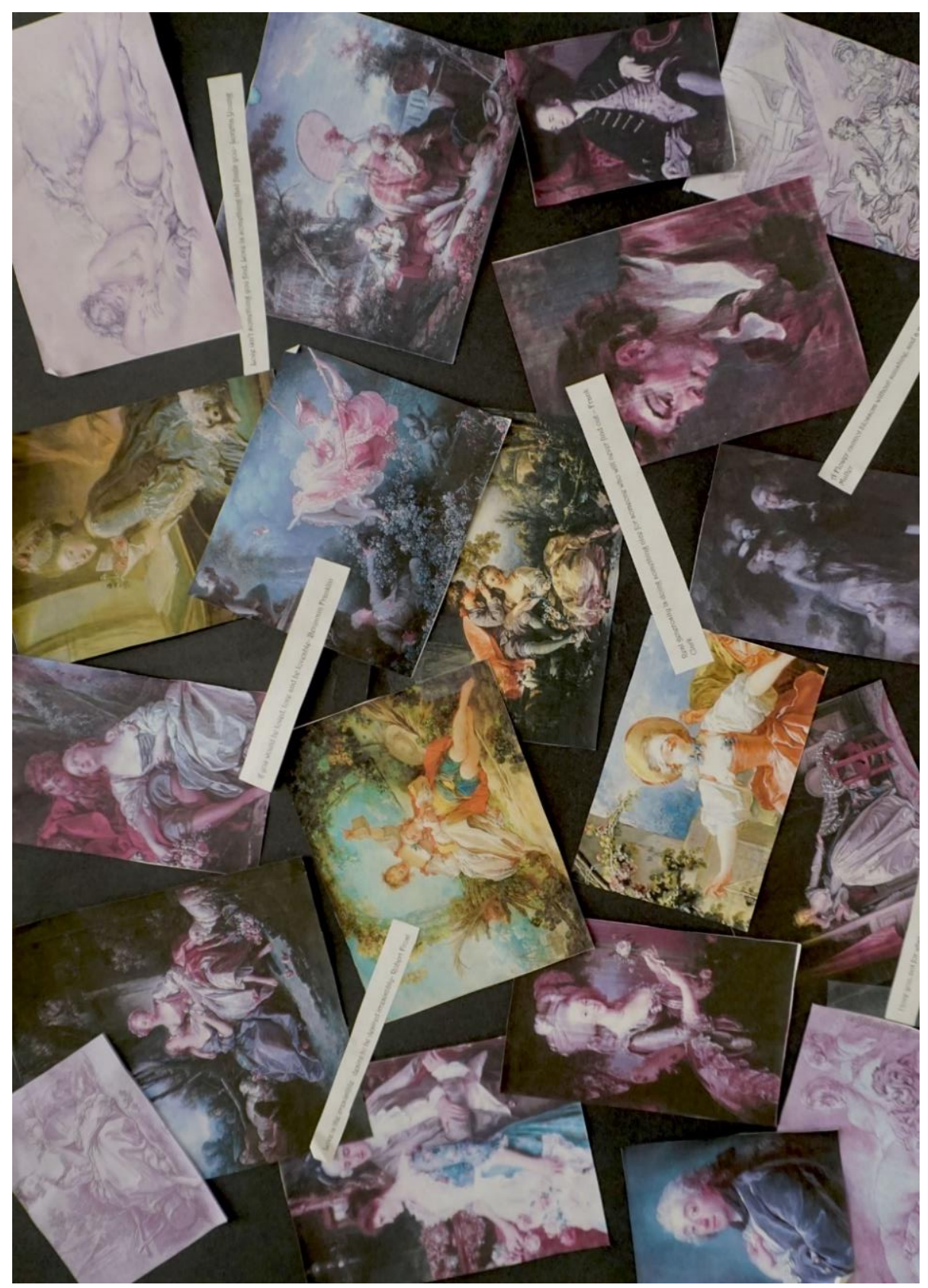

Figure 2.4: The Triumph of Love special world board with the inspiration paintings along with other paintings from the period, research photos, and quotes about love 


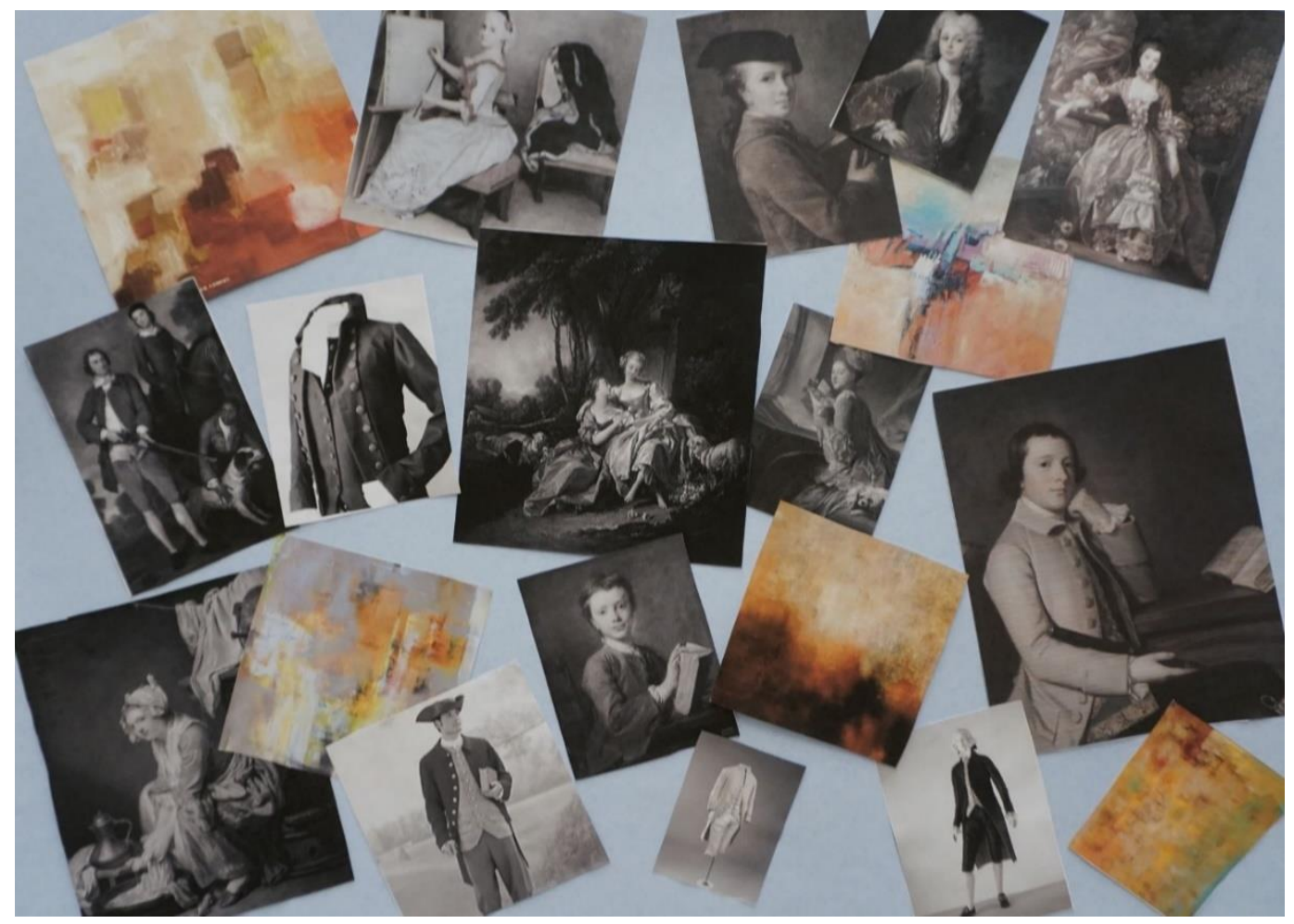

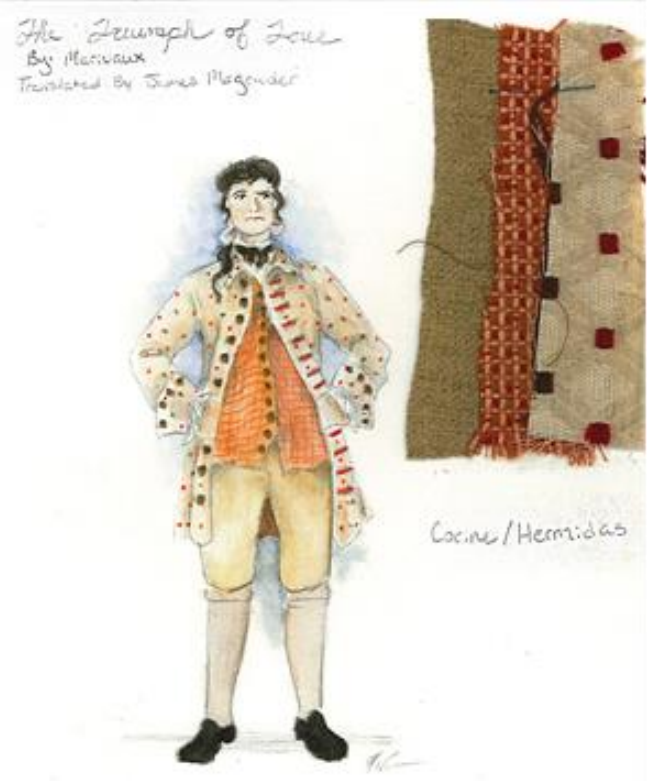

Corine

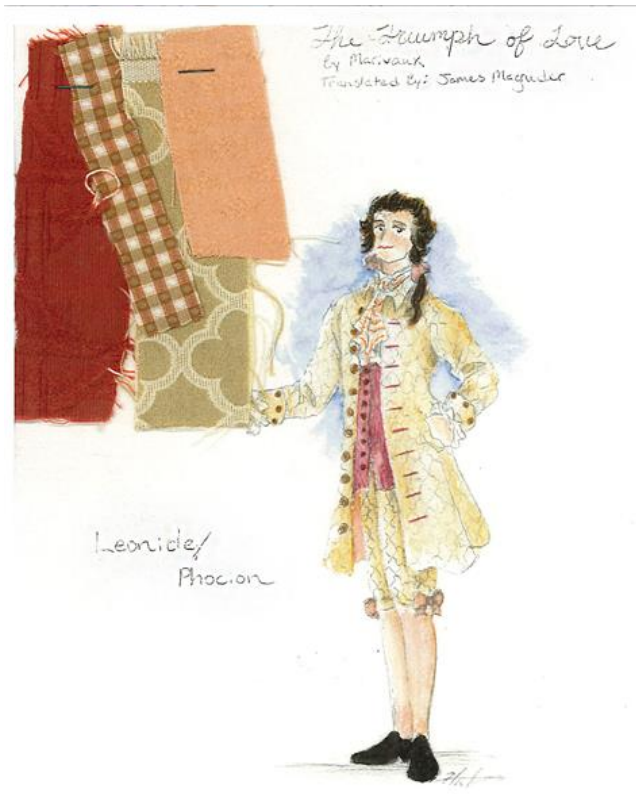

Léonide

Figure 2.5: The Triumph of Love Léonide and Corine Research (Top) and Color sketches (Bottom) 


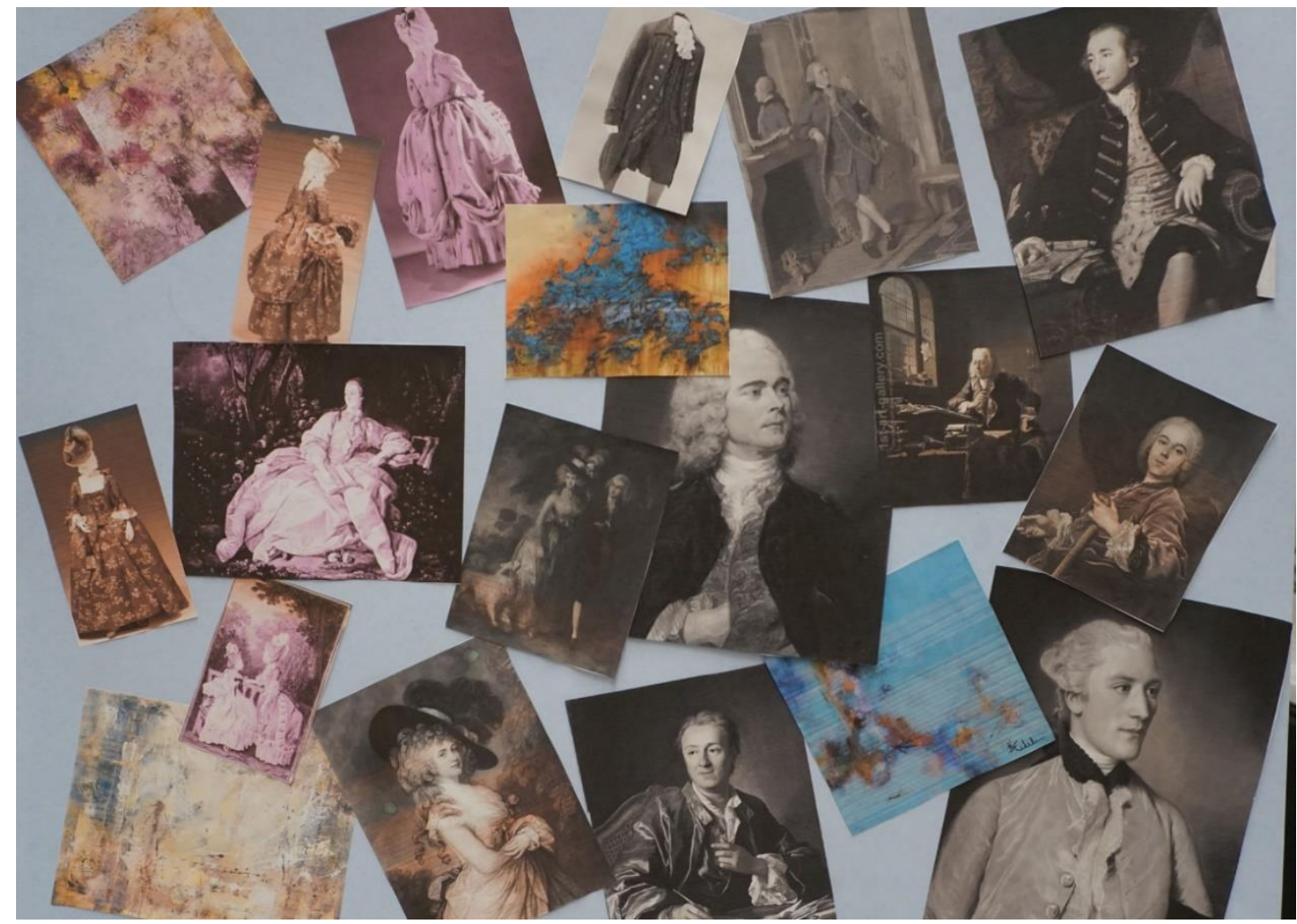

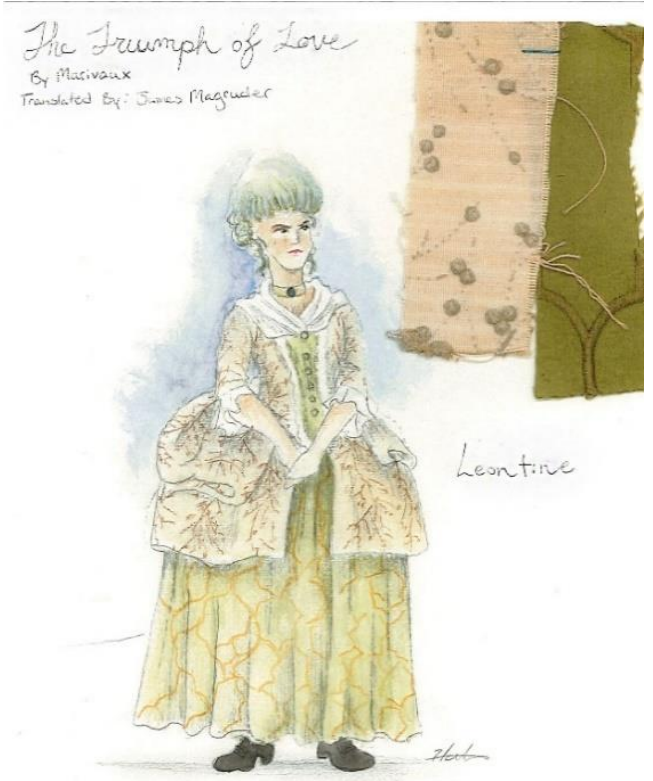

Léontine

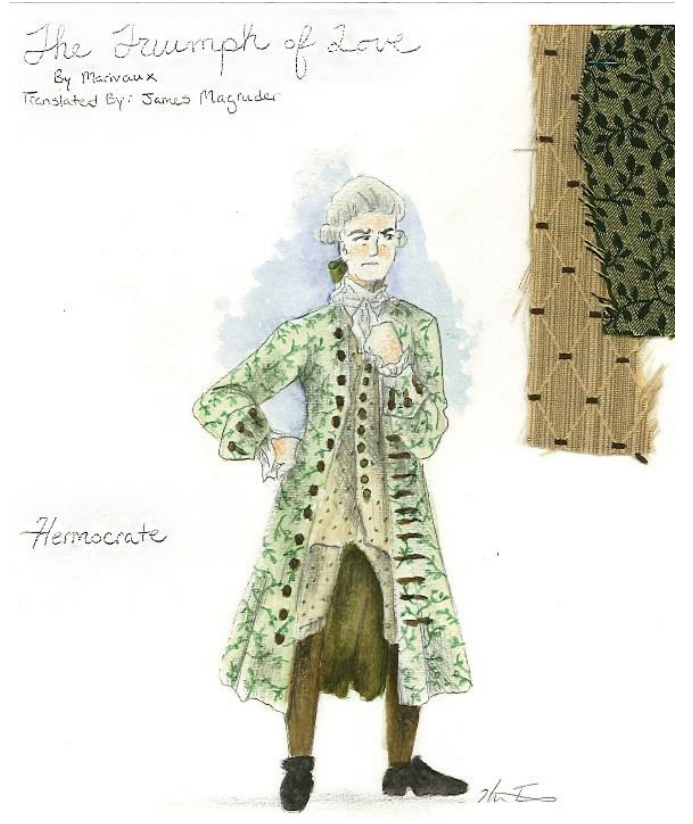

Hermocrate

Figure 2.6: The Triumph of Love Léontine and Hermocrate Research (Top) and color sketches (Bottom) 
Appendix Chapter 2
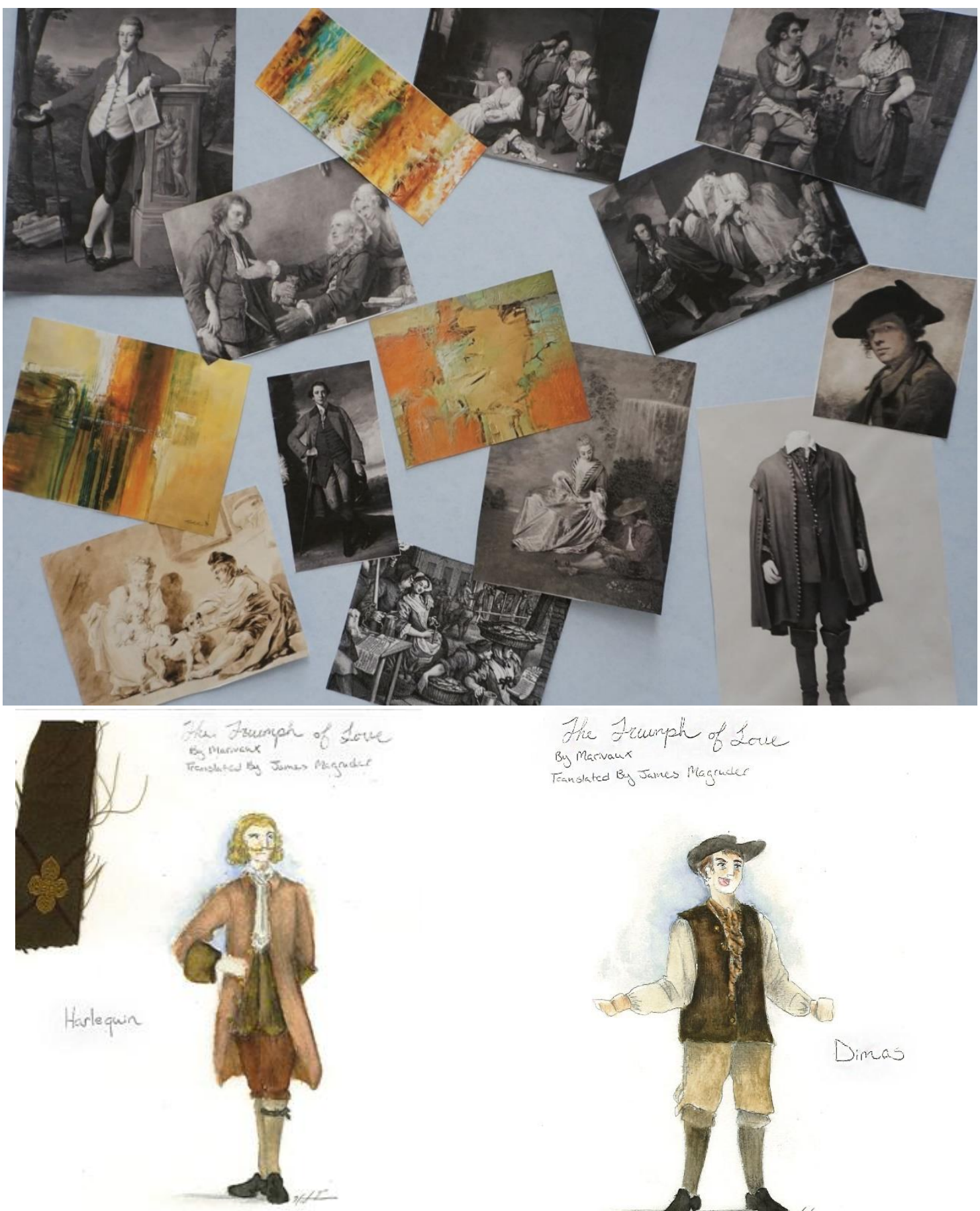

The Trumph of Loue
By marvaux
Teansiated By James Magruder

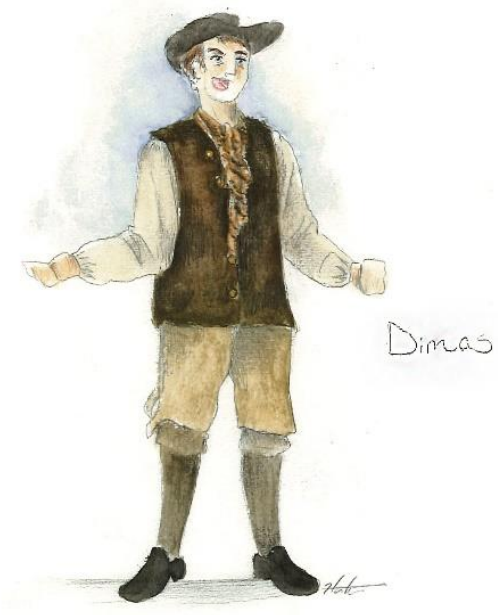

Harlequin

Dimas

Figure 2.7: The Triumph of Love Harlequin and Dimas Research (Top) and colored sketches (Bottom) 

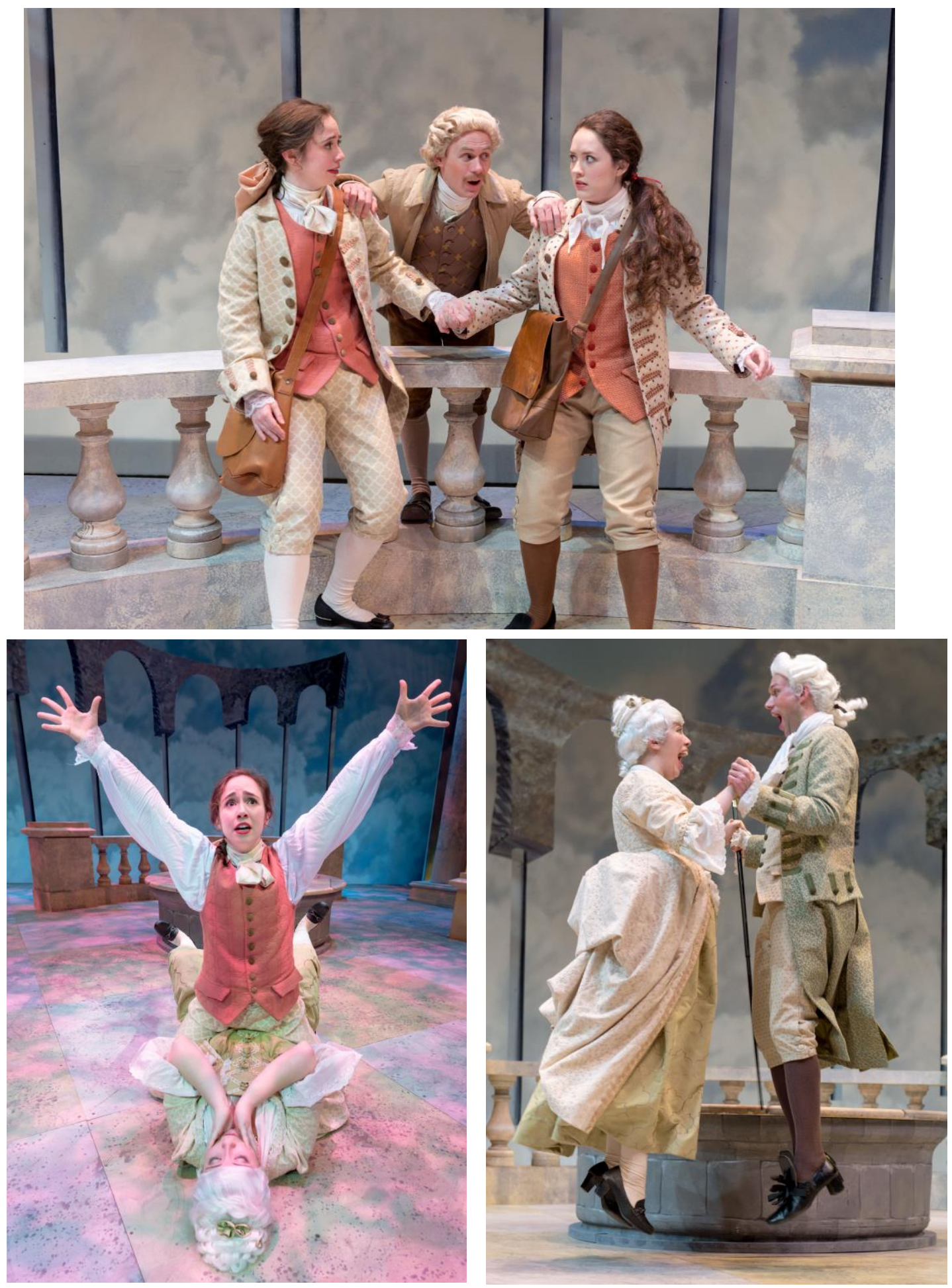

Figure 2.8: The Triumph of Love production photos taken by Michael Bailey, with Léonide, Harlequin, and Corine (Top), Léonide and Léontine (Left), Léontine and Hermocrate (Right) 


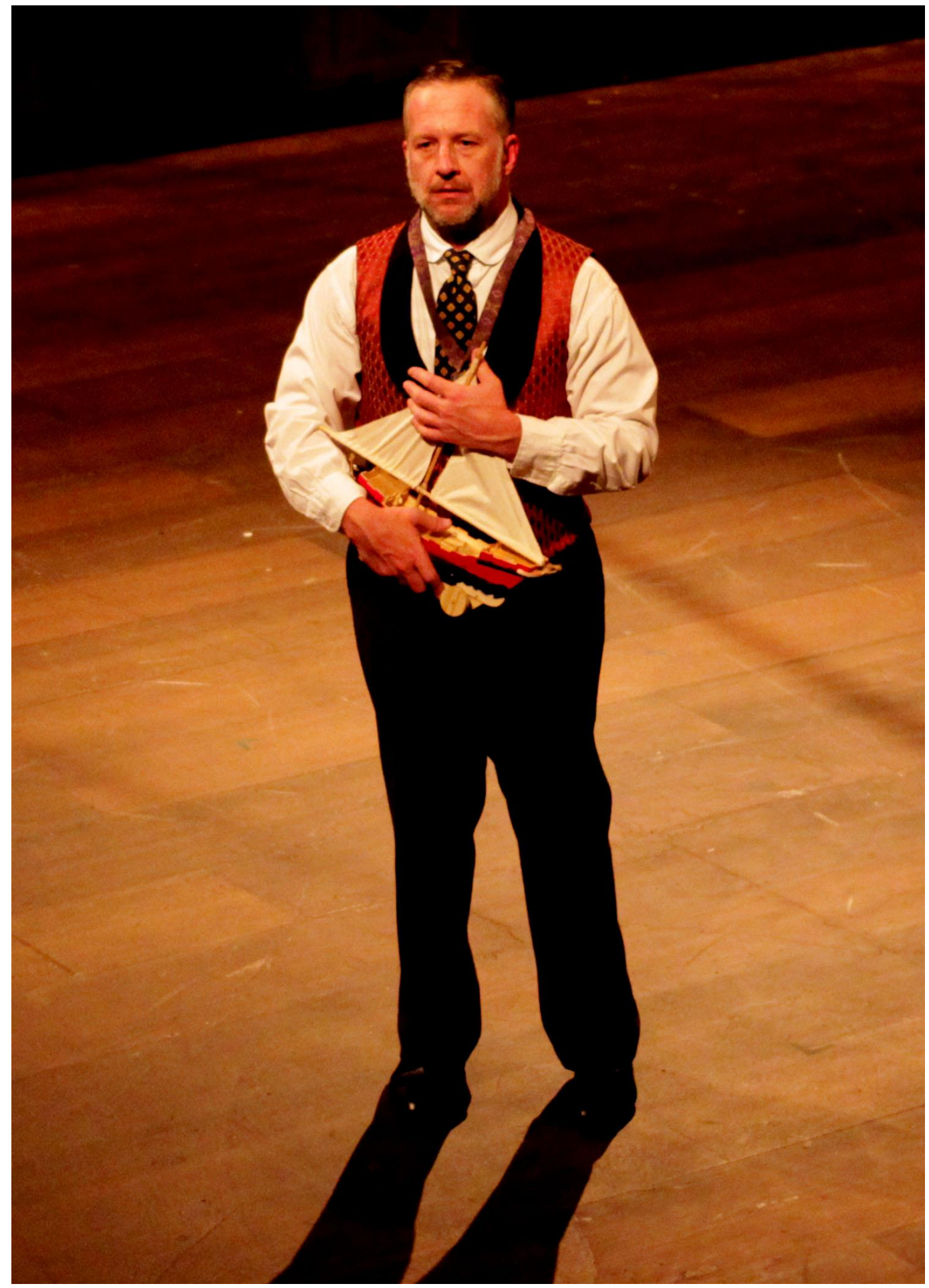

Figure 2.9 Shipwrecked! An Entertainment: The Amazing Adventures of Louis de Rougemont (as Told by Himself) production photo of Louis De Rougemont 
Appendix Chapter 2

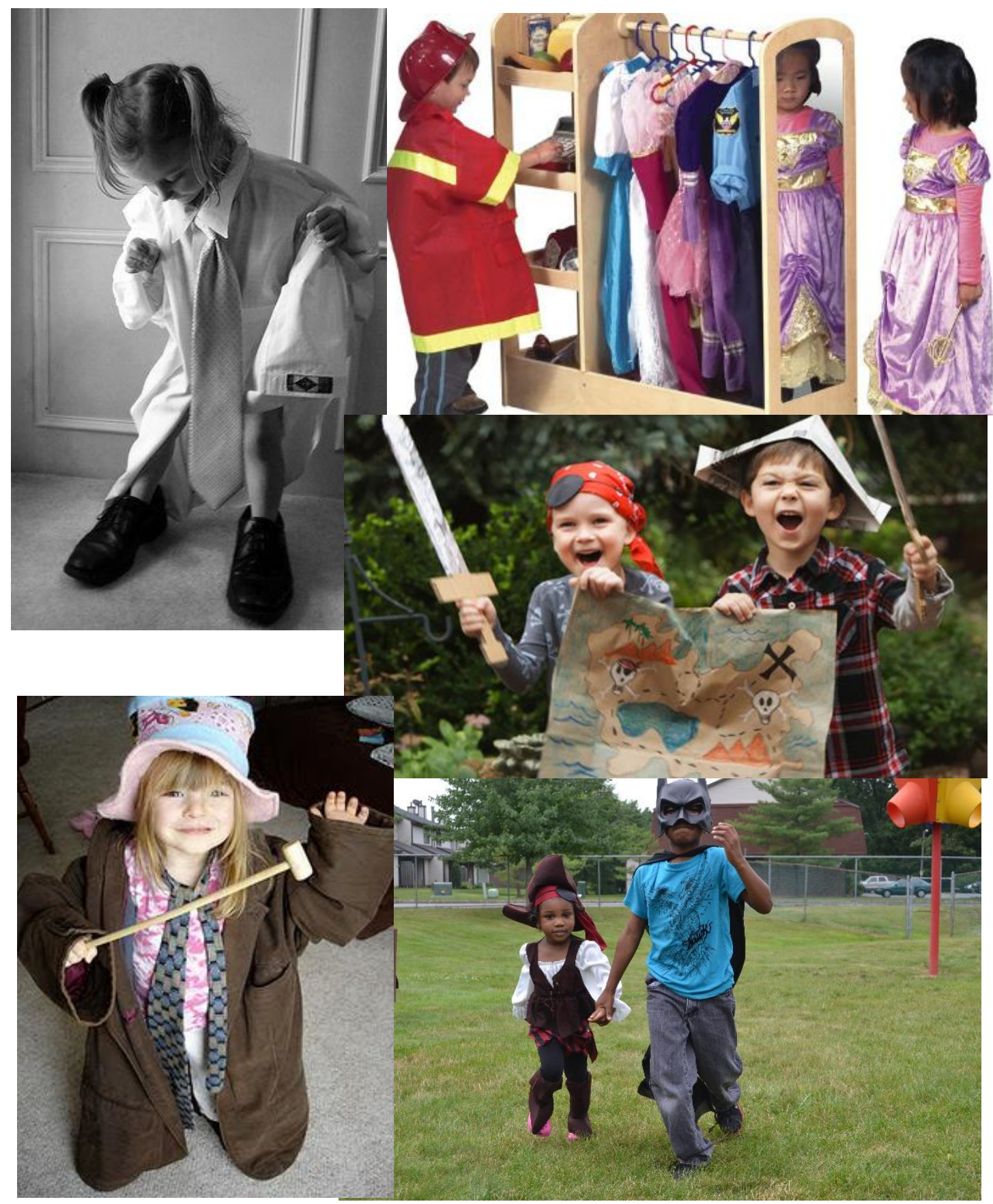

Figure 2.10: Shipwrecked! An Entertainment: The Amazing Adventures of Louis de Rougemont (as Told by Himself) inspiration pictures of children playing pretend 


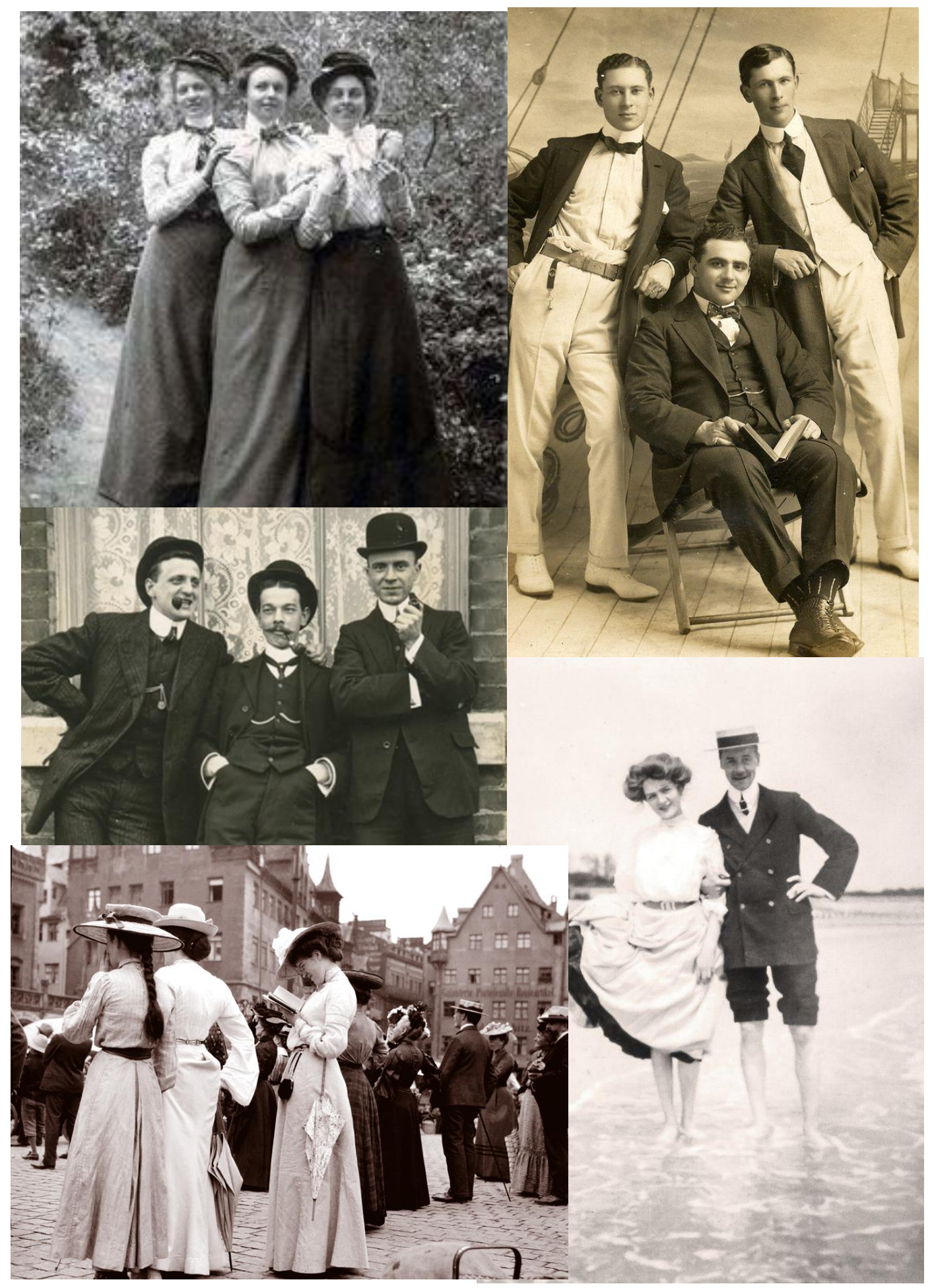

Figure 2.11: Shipwrecked! An Entertainment: The Amazing Adventures of Louis de Rougemont (as Told by Himself) Pictures of Victorian research 


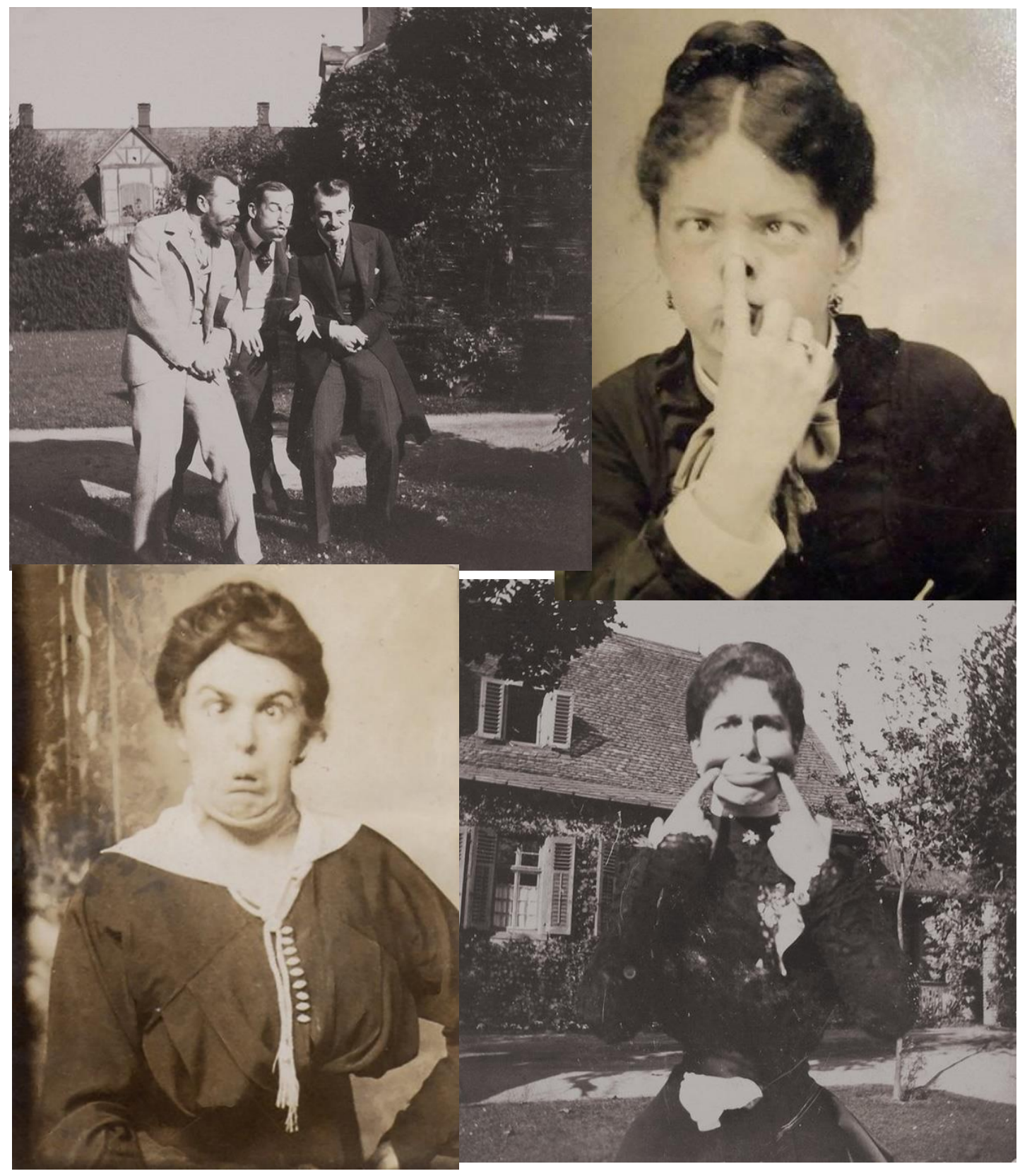

Figure 2.12: Shipwrecked! An Entertainment: The Amazing Adventures of Louis de Rougemont (as Told by Himself) Pictures of silly faces in the Victorian era 

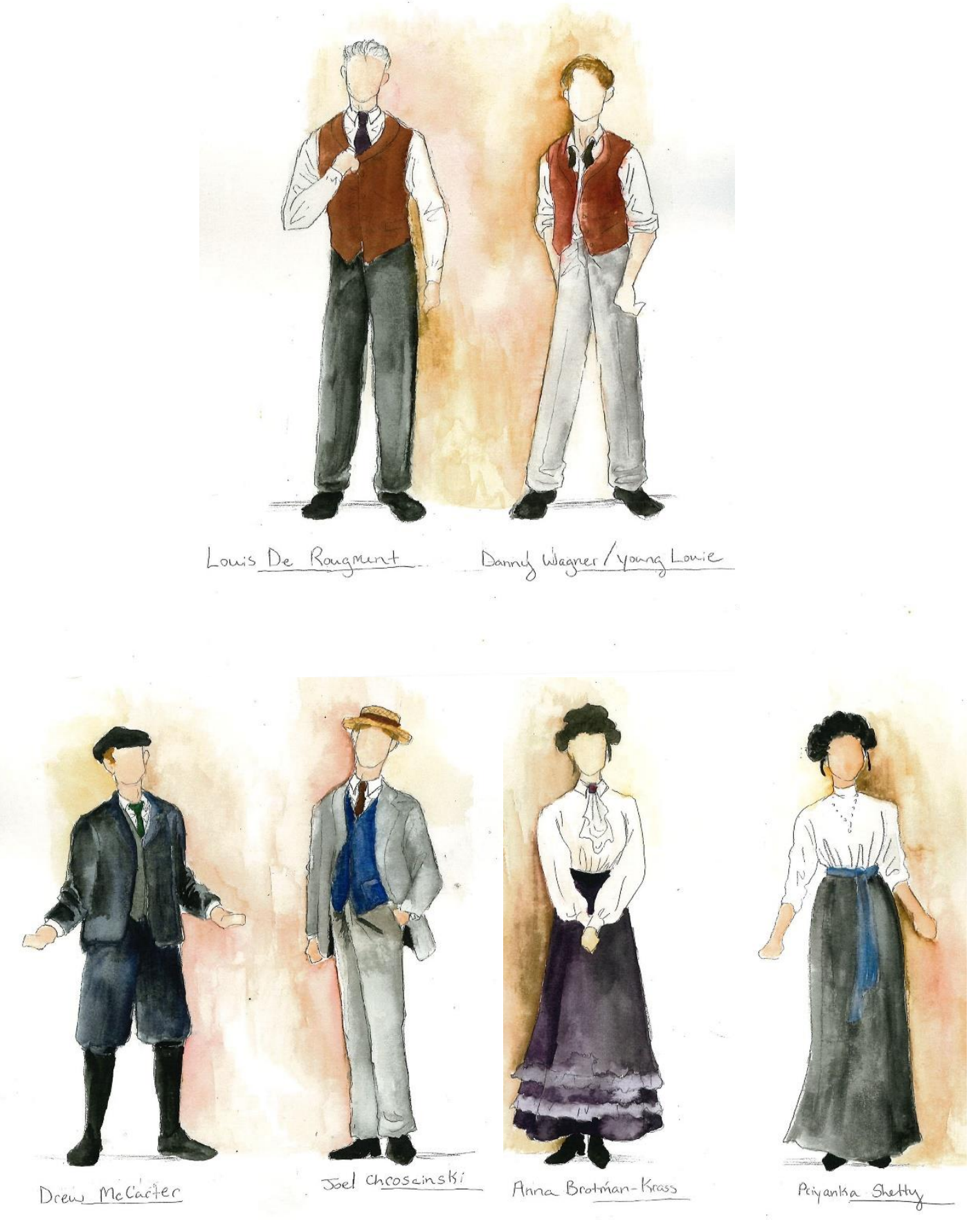

Figure 2.13: Shipwrecked! An Entertainment: The Amazing Adventures of Louis de Rougemont (as Told by Himself) color sketches of Old and Young Louis De Rougemont (Top), and 2 male and two female Victorian troupe members (Bottom) 

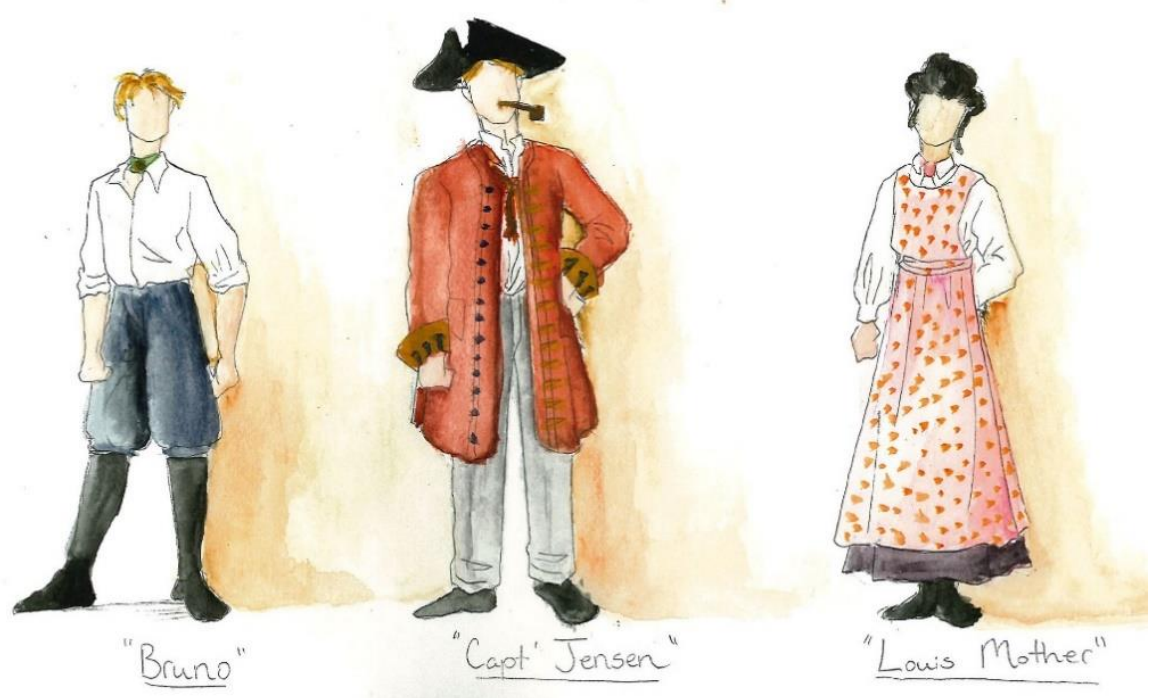

Figure 2.14: Shipwrecked! An Entertainment: The Amazing Adventures of Louis de Rougemont (as Told by Himself Group plates of the story characters (from left to right) Bruno, Captain Jensen, and Louis Mother in

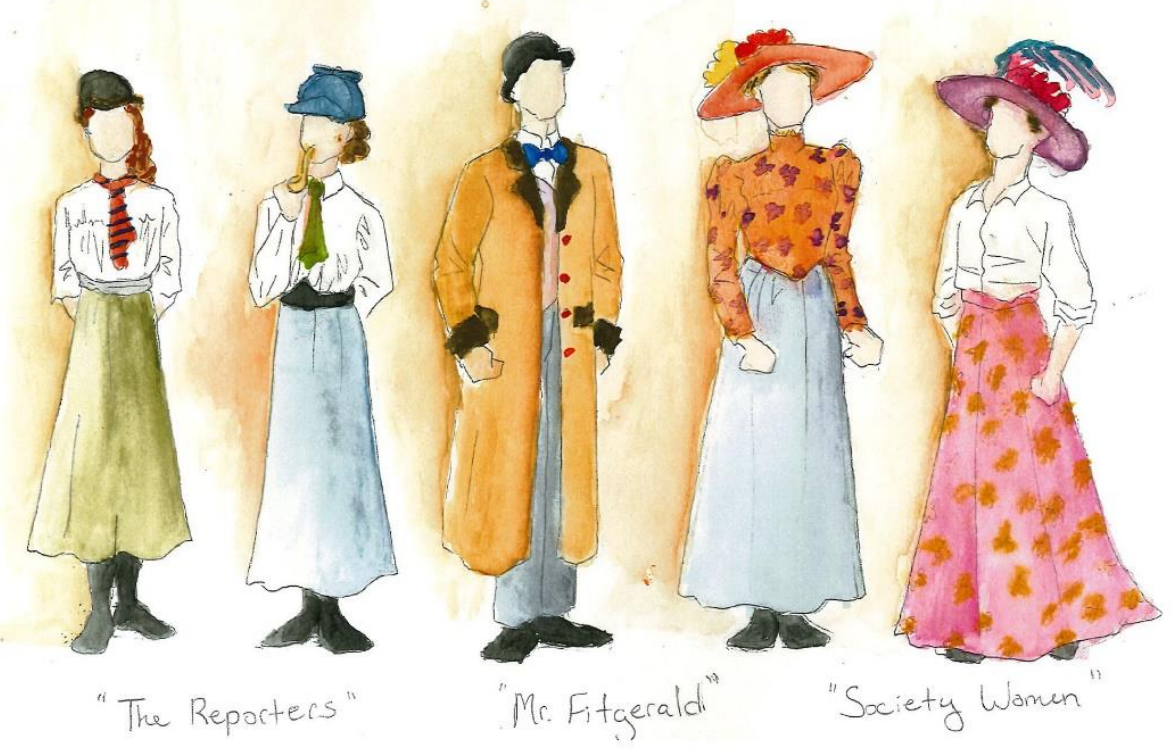

Figure 2.15: Group plates of the story characters (from left to right) The Reporters, Mr. Fitzgerald, and The Society Women in Shipwrecked! An Entertainment: The Amazing Adventures of Louis de Rougemont (as Told by Himself) 

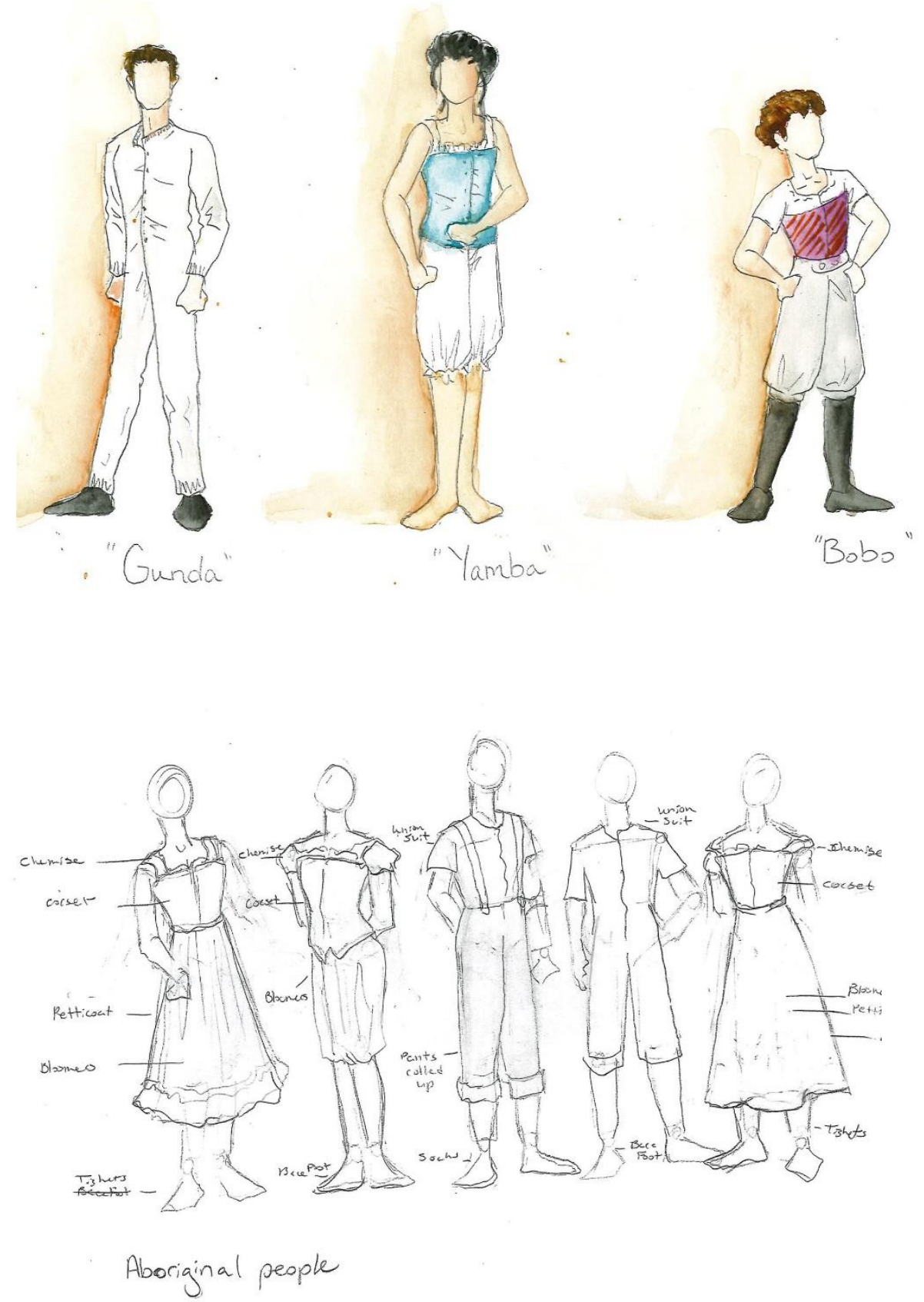

Rough sketch of the ensembles as Aboriginals

Figure 2.16: Shipwrecked! An Entertainment: The Amazing Adventures of Louis de Rougemont (as Told by Himself) Aboriginal color sketches and rough sketches 

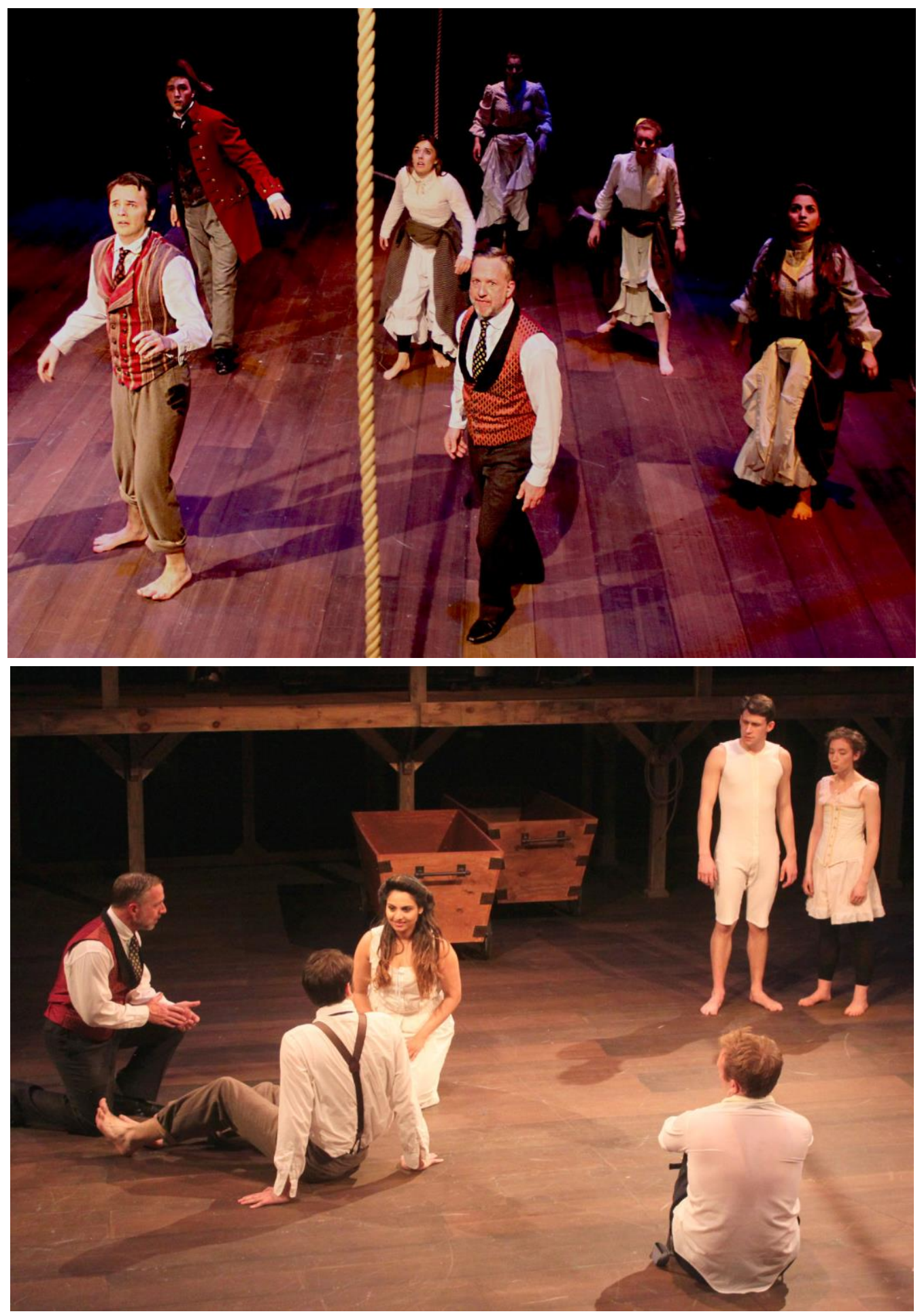

Figure 2.17: Shipwrecked! An Entertainment: The Amazing Adventures of Louis de Rougemont (as Told by Himself) production photos. Features the young and old Louis with cast (top) and young and old Louis with Yamba, Gunda, Bobo, and Bruno (bottom). 


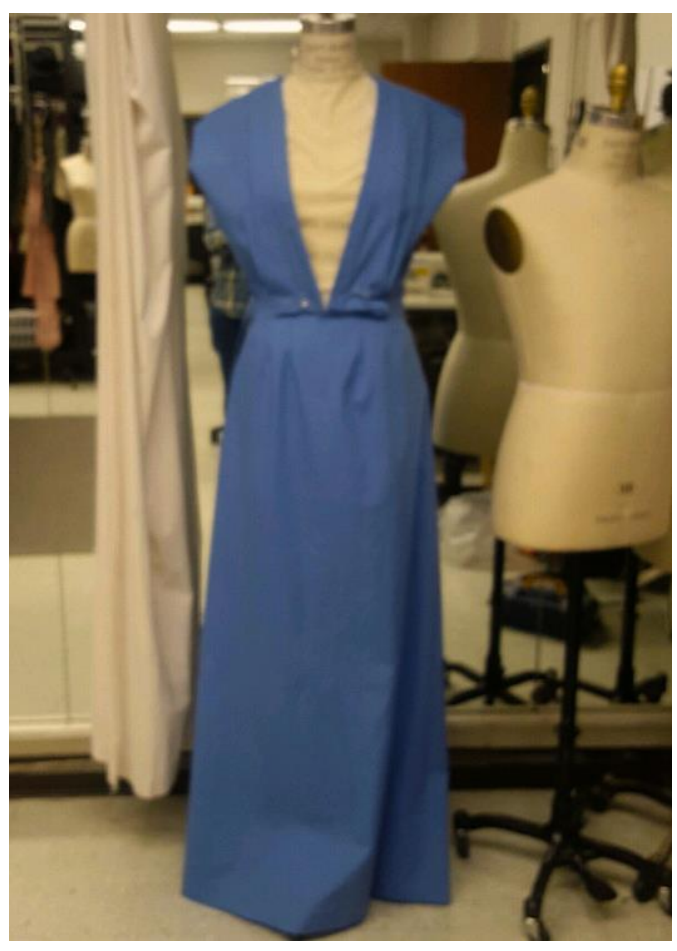

First build of Polly Peachum's Dress

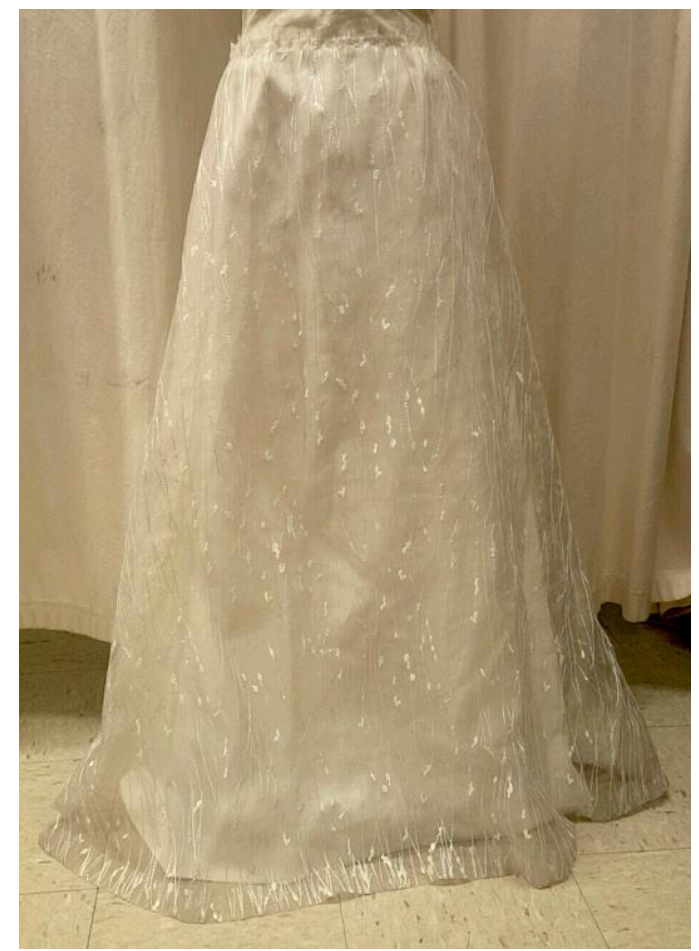

Blood Wedding Wedding Skirt

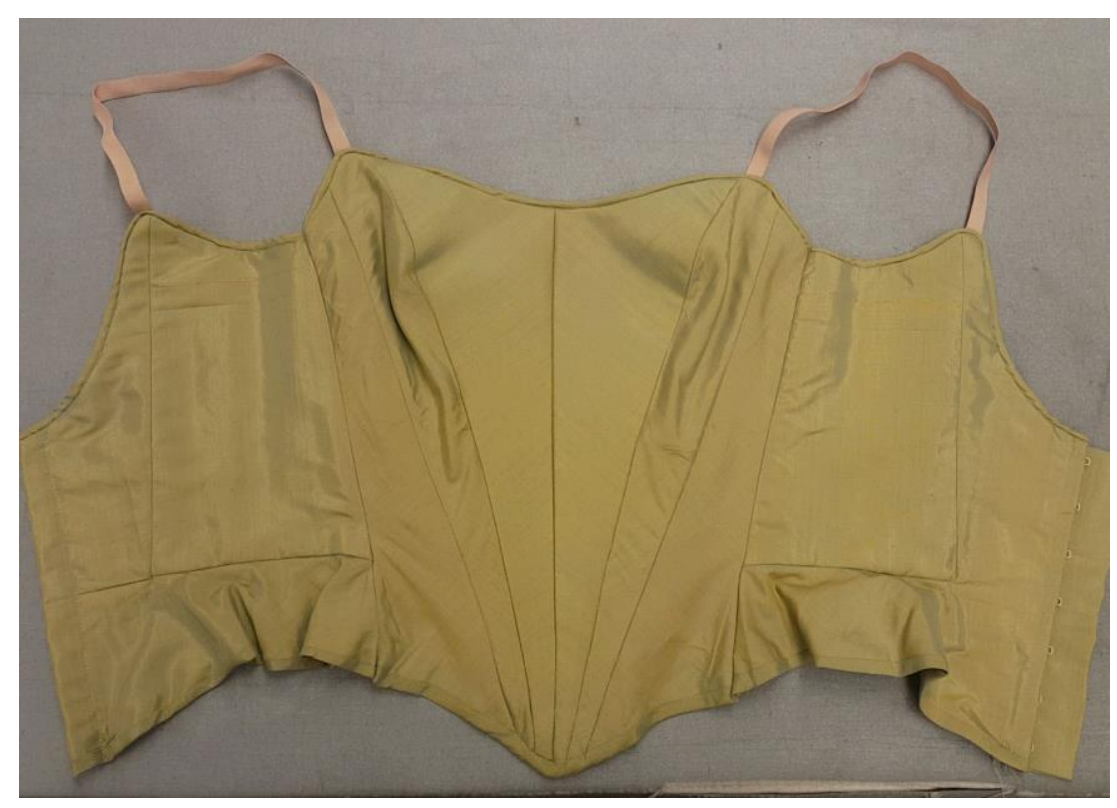

Ballet Bodice

Figure 3.1: Process photos of Polly Peachum's Dress, The wedding skirt from Blood Wedding and a Ballet Bodice from creative draping, Spring 2017. 


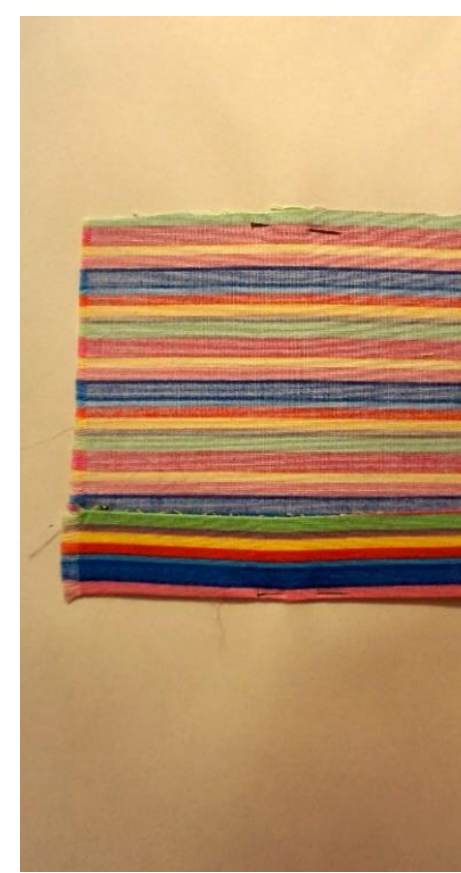

Slip Stitch

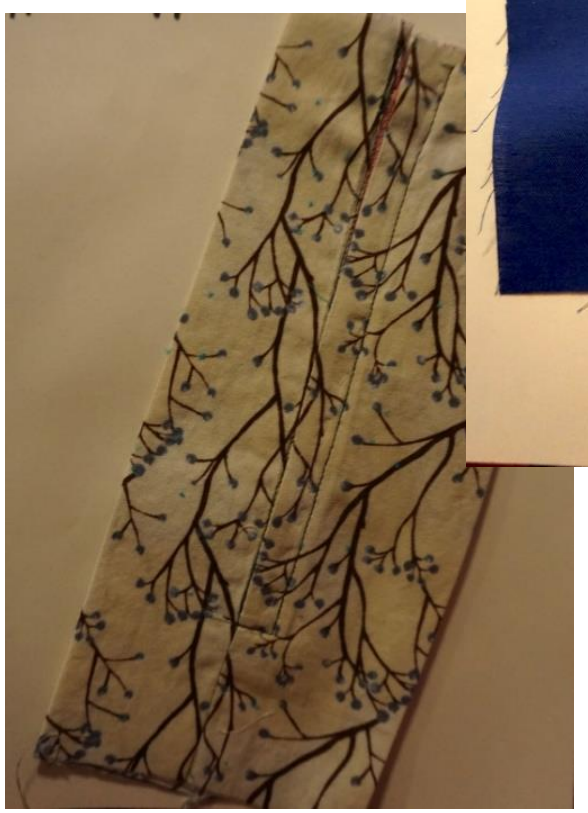

Lap Zipper

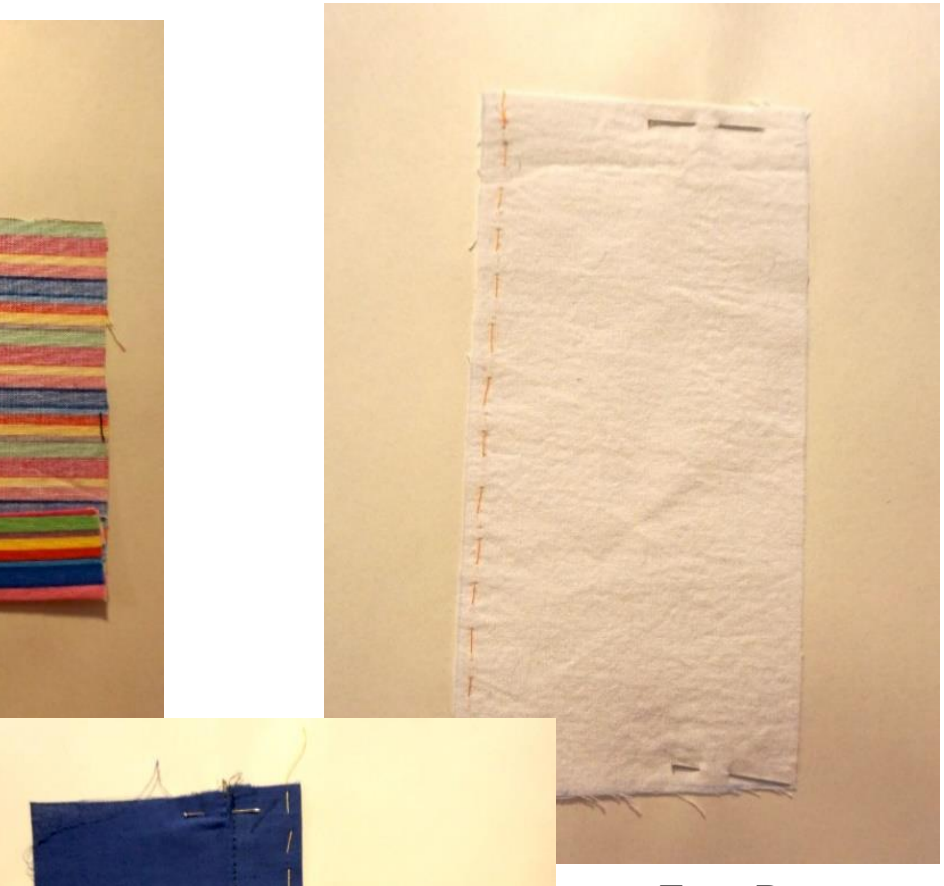

Even Baste

Even Baste

Tailor Placket

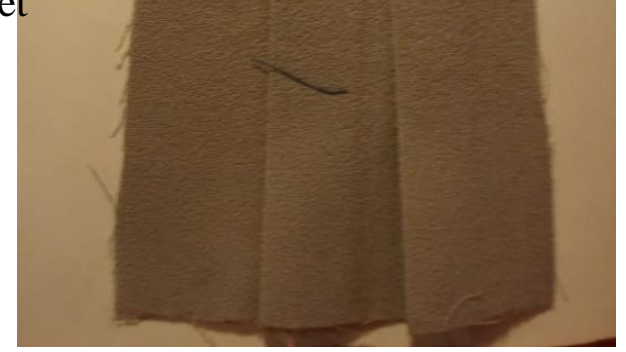

Shaped Pleat

Figure 3.2: Technology couture samples, fall 2014 


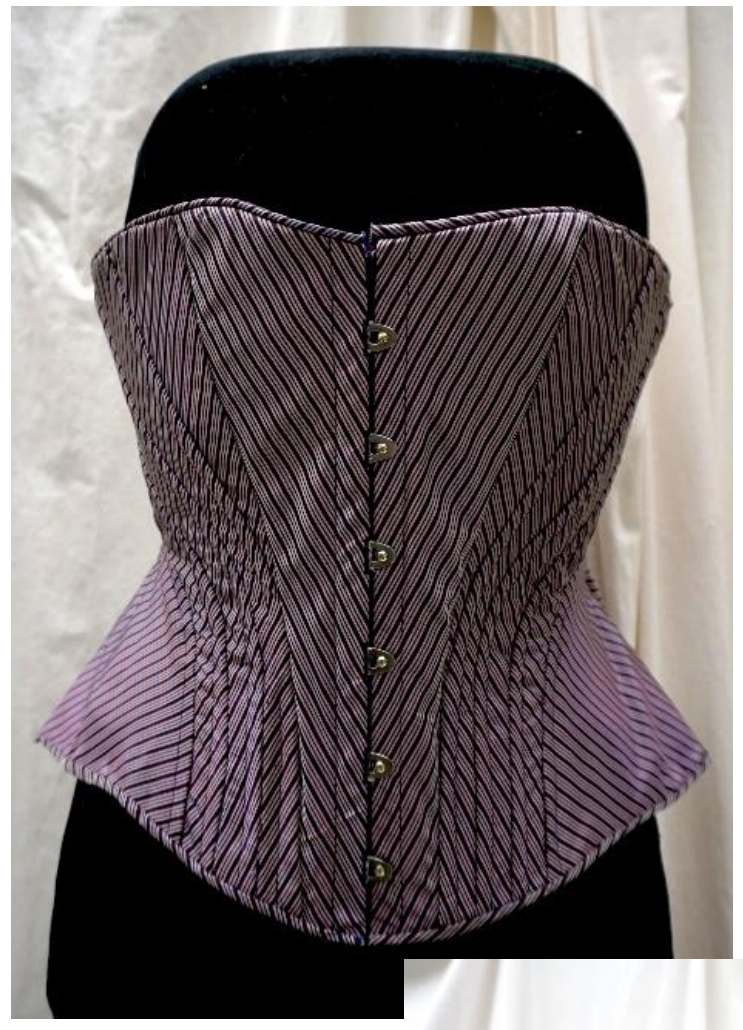

1890’s Corset

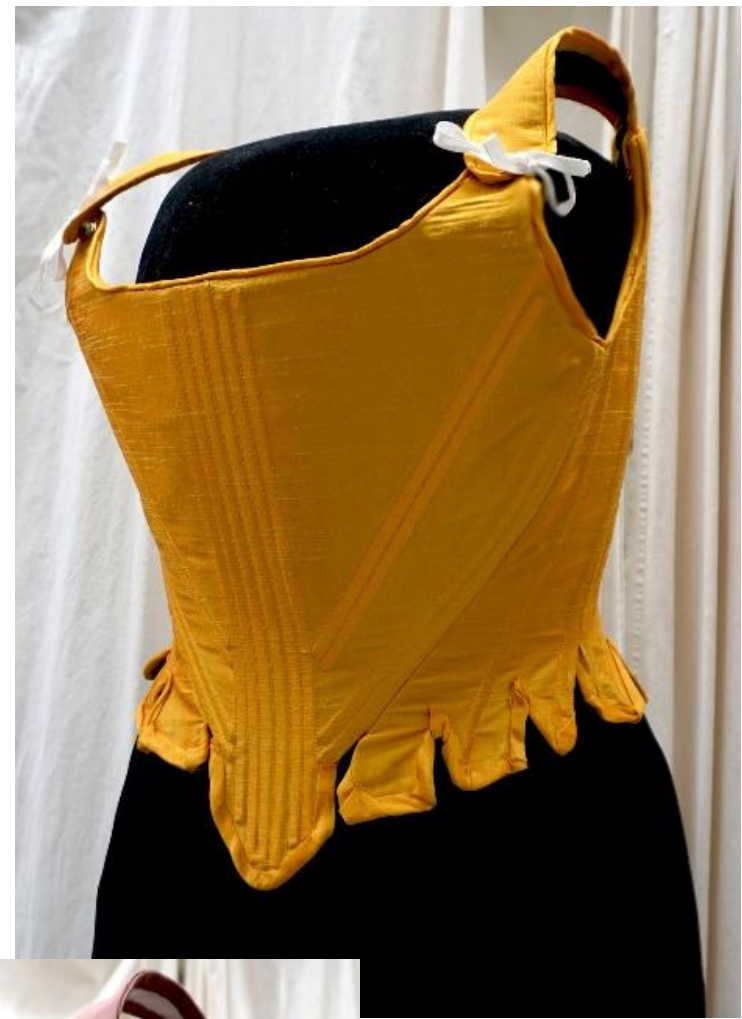

Georgian Corset

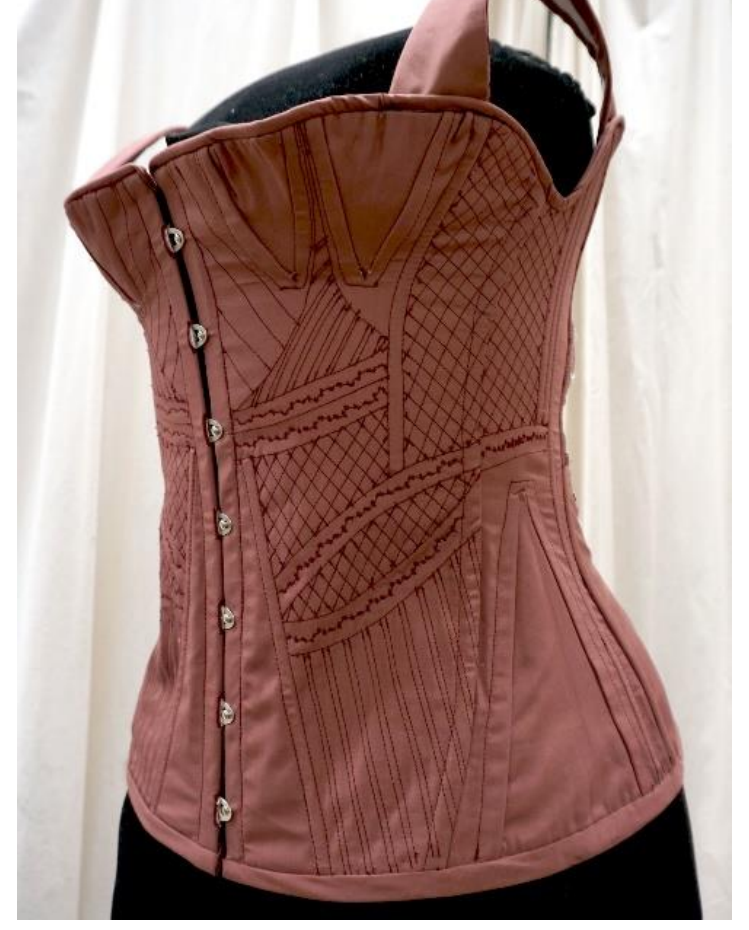

Umpire Corset

Figure 3.3: Corsetry work throughout my graduate career: From the left is the 1890's, then the Georgian, followed by the Umpire Corset 


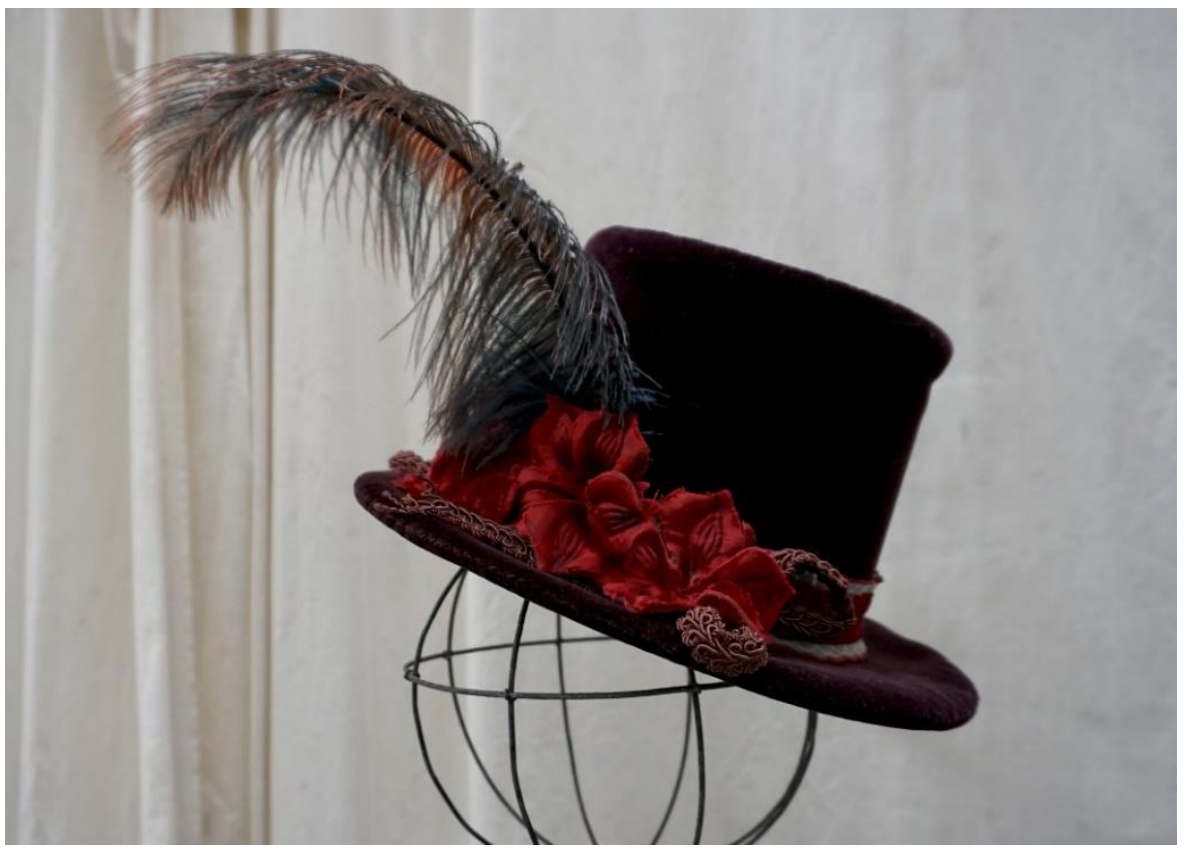

Figure 3.4: Victorian Toque Hat Costume Craft, Fall 2016

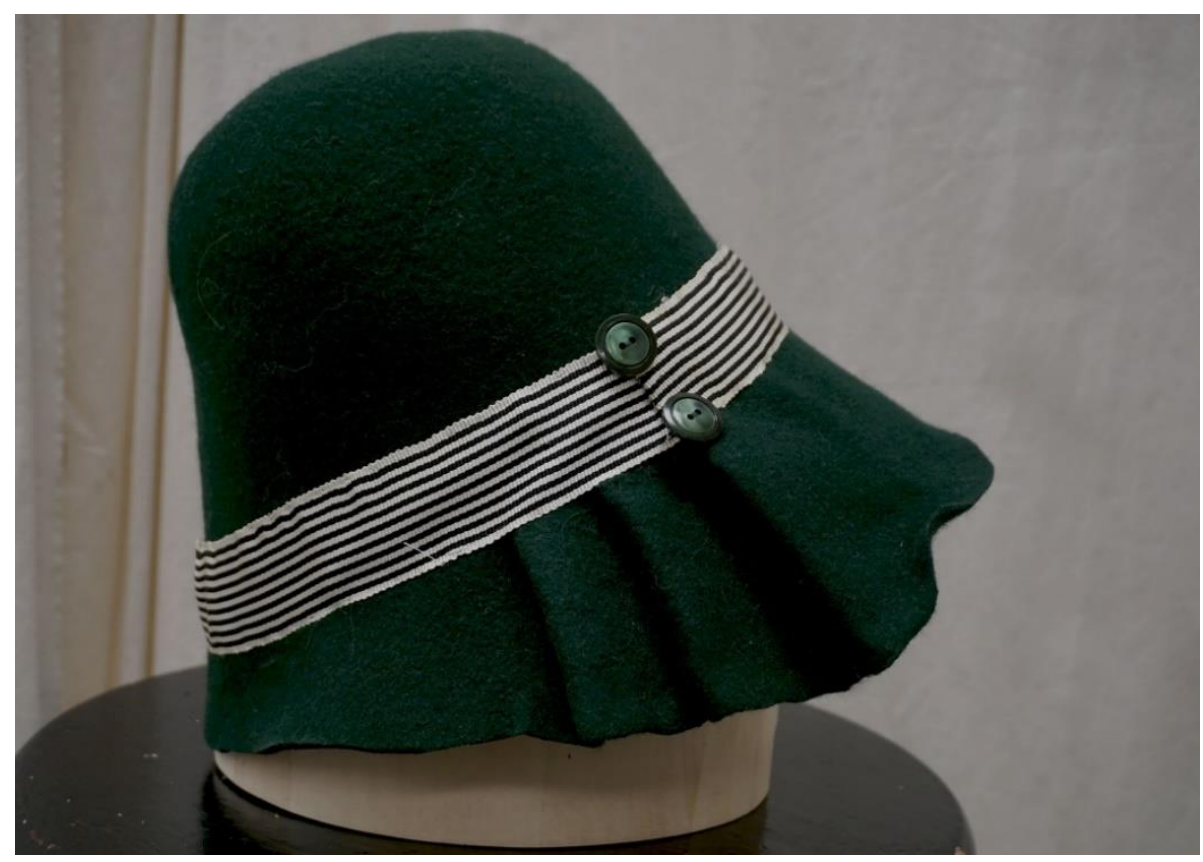

Figure 3.5: 1920’s Cloche Hat Costume Craft, Fall 2 


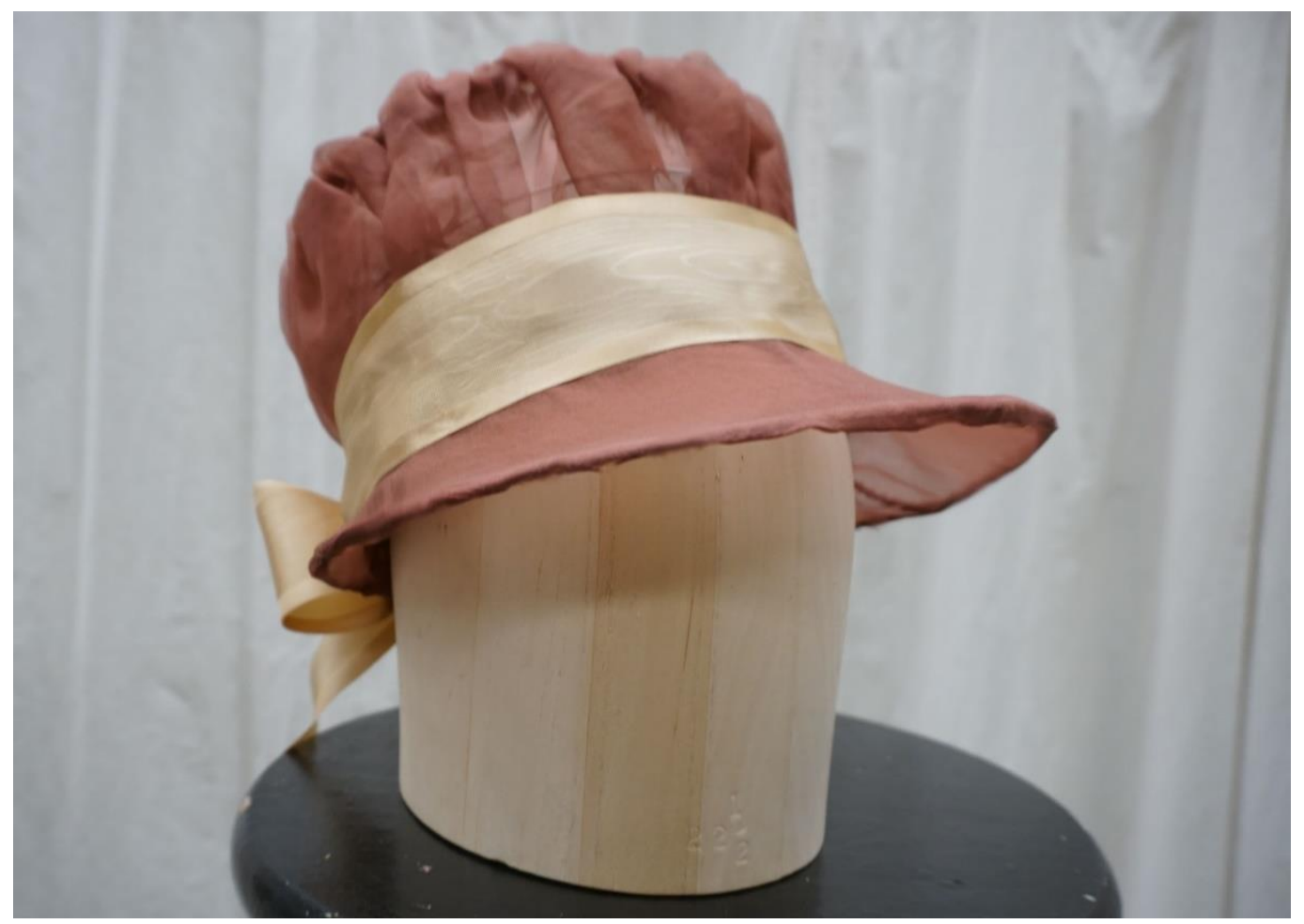

Figure 3.6: Wire framed Bonnet Costume Craft, Fall 2016

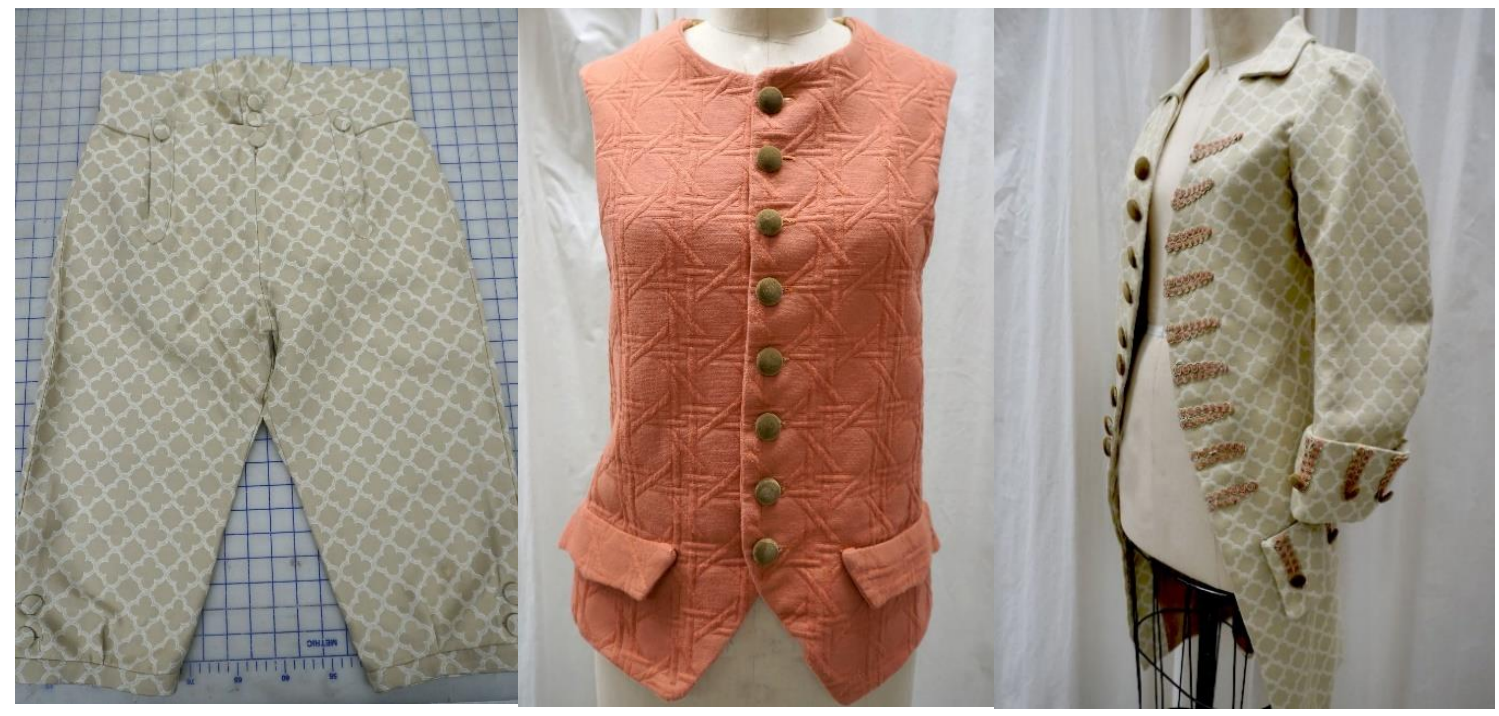

Figure 3.7: The Triumph of Love Léonide's fall front breeches, waistcoat, and coat 

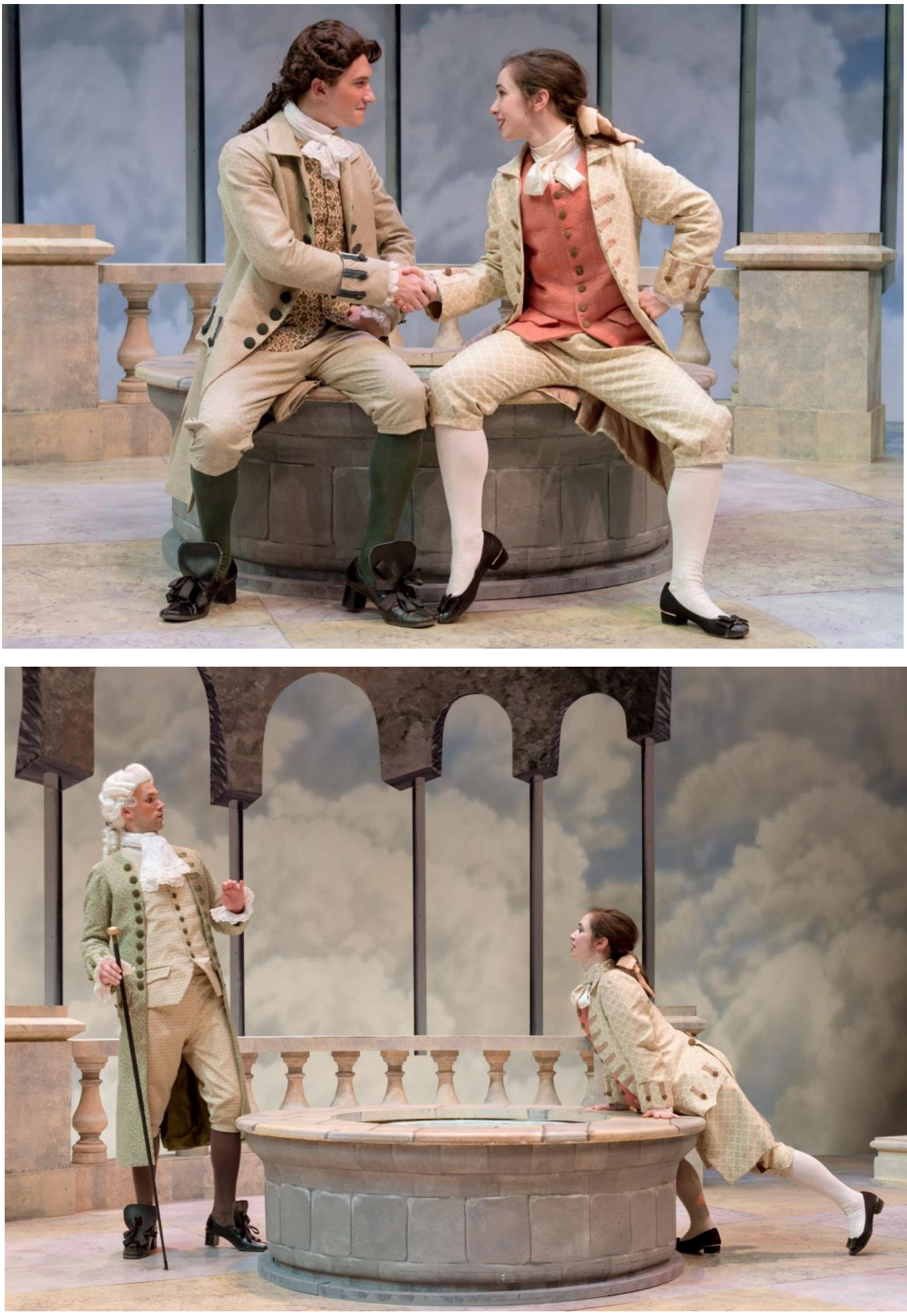

Figure 3.8: The Triumph of Love production photos taken by Michael Bailey of Léonide wearing her ensemble with characters Agis (Top) and Hermocrate (Bottom). 


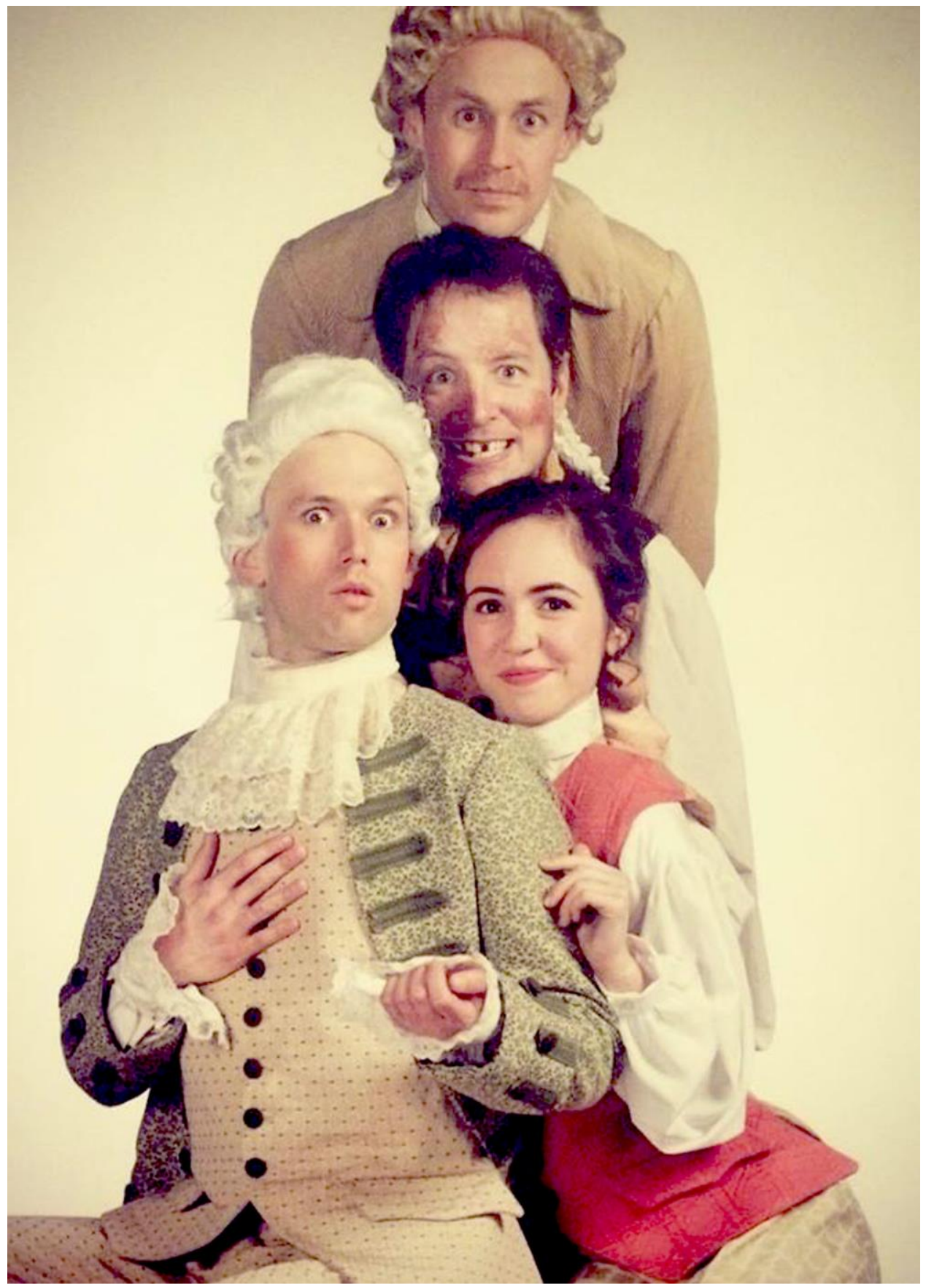

Figure 3.9: The Triumph of Love Publicity photo taken by Michael Bailey with (from the top) Harlequin, Dimas, Hermocrate, and Léonide 

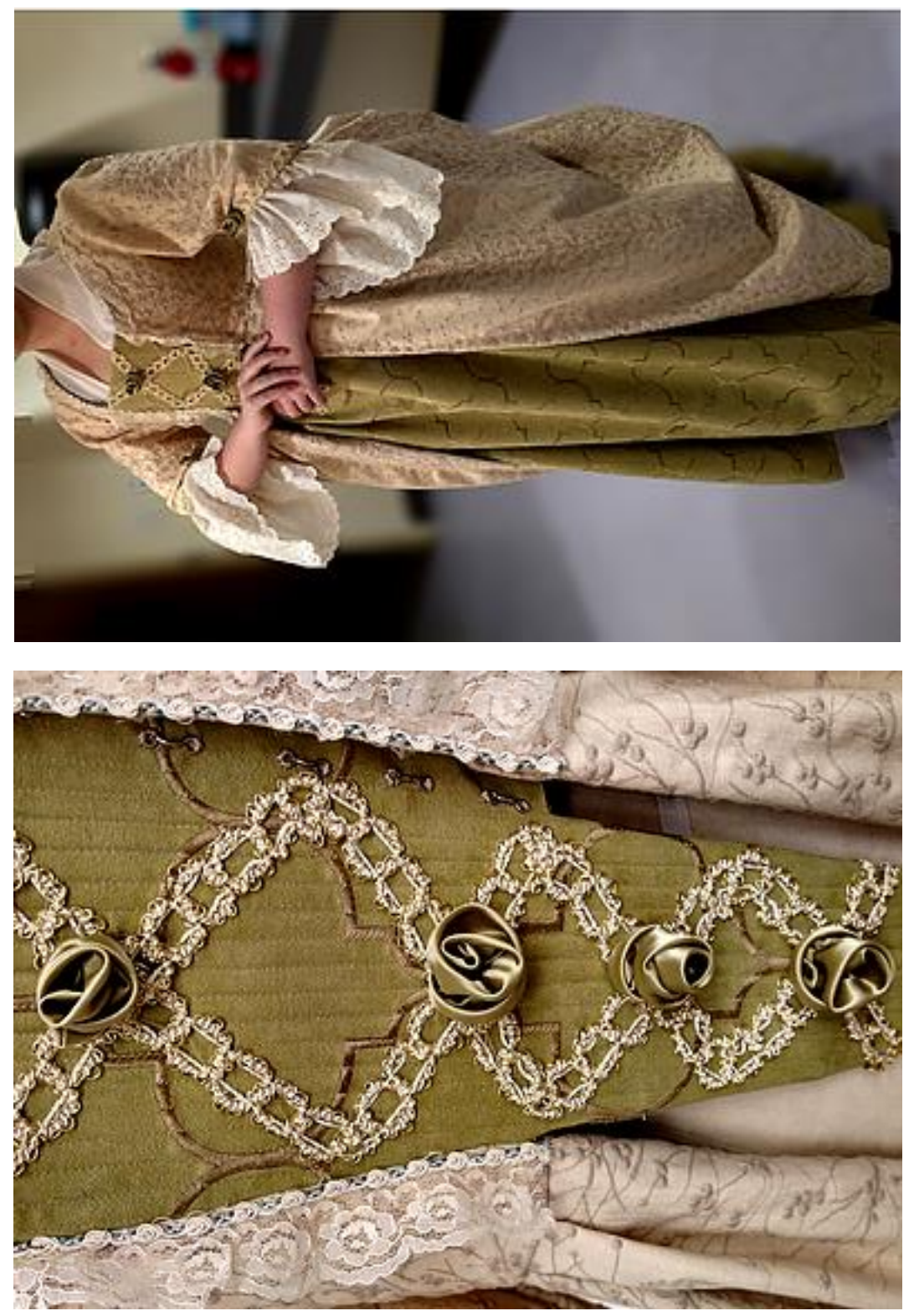

3.10: The Triumph of Love close up of decorated stomacher (left) and additional trim, lace and fishu (Right) on Léontine's polonaise gown 


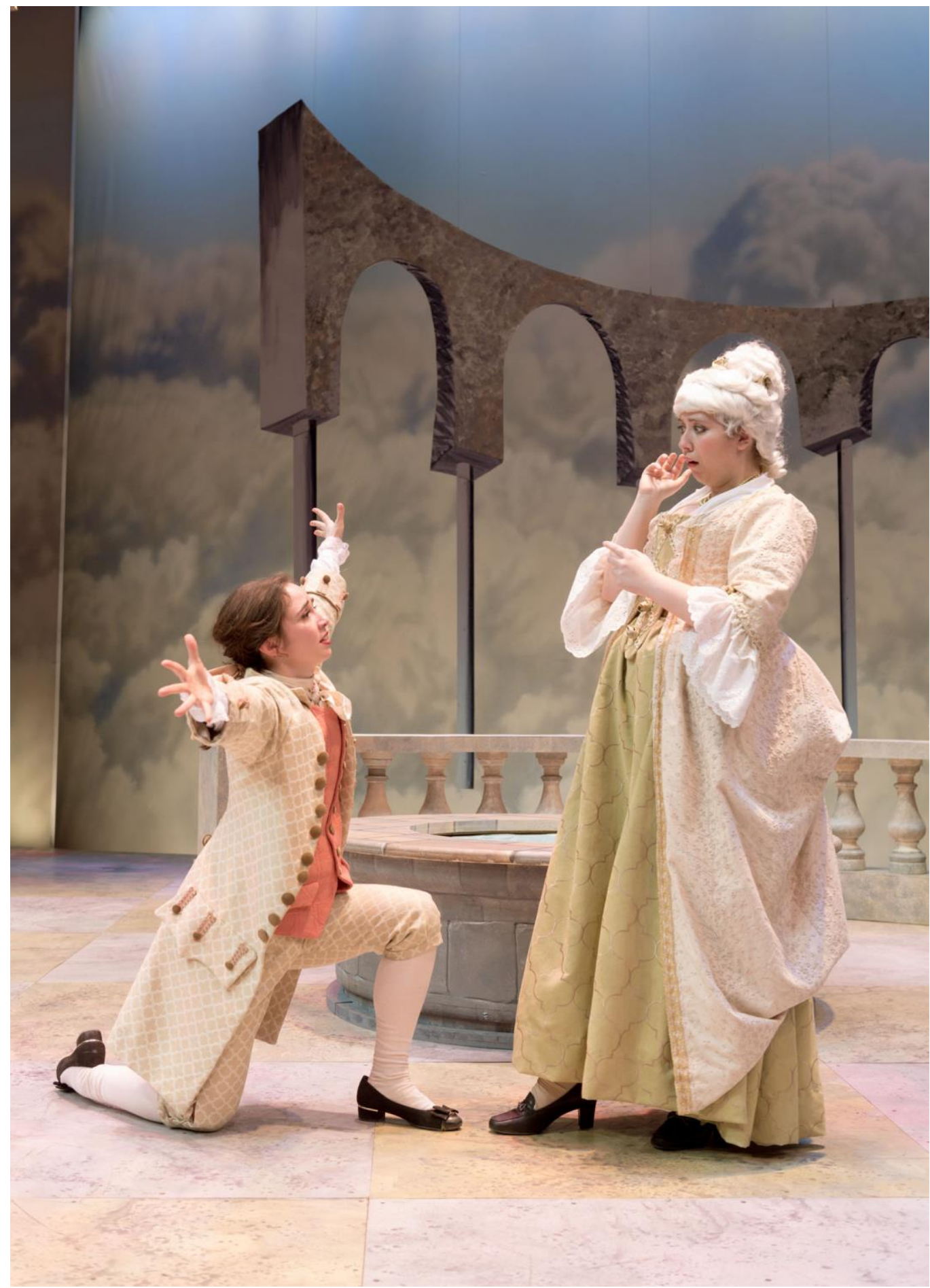

Figure 3.11: The Triumph of Love production photo taken by Michael Bailey of Léontine's finished polonaise with Léonide 


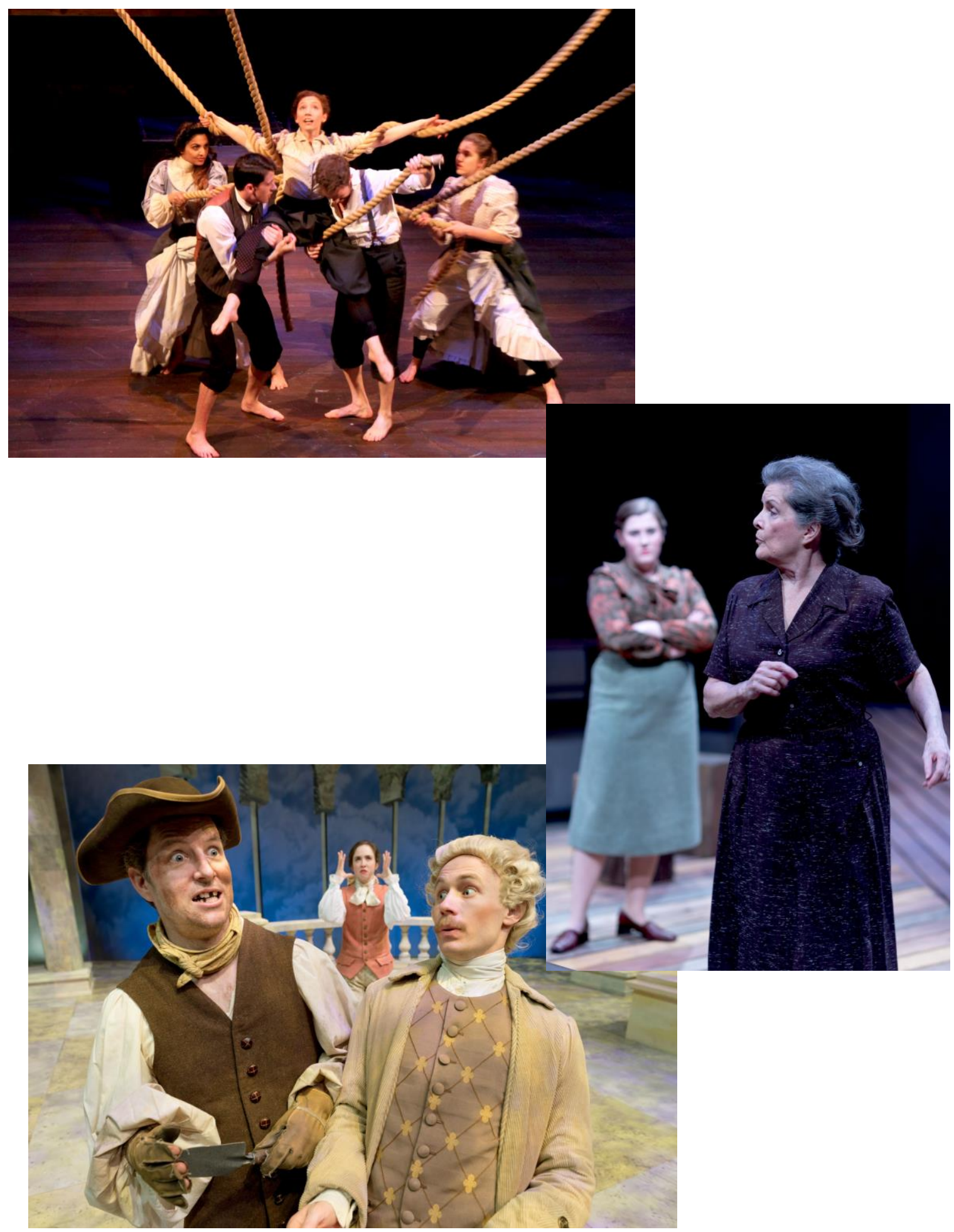

Figure C.1: Shipwrecked! An Entertainment, the Amazing Adventures of Louis De Rougemont (As Told by Himself), The Rimers of Eldritch, and The Triumph of Love production photos taken by Michael Bailey. 
Bibliography

Bruna, Denis. Fashioning the body: an intimate history of the silhouette. New York: Published for Bar Graduate Center, Decorative Arts, Design History, Material Culture by Yale U Press, 2015. Print.

Dirix, Emmanuelle, and Charlotte Fiell. 1930s fashion: the definitive sourcebook. London: Carlton Ltd, 2015. Print.

Dirix, Emmanuelle, and Charlotte Fiell. 1940s fashion: the definitive sourcebook. London: Goodman Fiell, 2013. Print.

Edwards, B. Drawing on the artist within: an inspirational and practical guide to increasing your creative powers. New York: Fireside Book, 1987. Print.

Gernsheim, Alison. Victorian \& Edwardian fashion: a photographic survey. New York: Dover Publications, 1981. Print.

Guy, John. Victorian life. Tunbridge: Ticktock, 1997. Print.

Fragonard, Jean-Honoré, and C. F. Foerster. Jean Honoré Fragonard: ausgewählte Handzeichnungen. Berlin: Im Propyläen-Verlag, 1940. Print.

Fukai, Akiko, and Tamami Suoh. Fashion from the 18th to the 20th century: the Kyoto Costume Institute. Köln: Taschen, 2004. Print.

Hart, Avril, and Susan North. Seventeenth and eighteenth-century fashion in detail. London: V\&A, 2009. Print.

Hodge, Francis. Play directing: analysis, communication, and style. Englewood Cliffs: Prentice-Hall, Inc., 1982. Print.

Lowery, Allison. Historical wig styling: Ancient Egypt to the 1830s. Oxford: Focal, 2013. Print.

Marivaux, Pierre, and James Magurder. The Triumph of Love. 440 park ave. New York, NY 10016: Dramatists Play Service INC., n.d. Print.

Margulies, Donald. Shipwrecked! An Entertainment The Amazing Adventures of Louis De Rougemont (As Told By Himself). 440 park ave. New York, NY 10016: Dramatists Play Service INC., n.d. Print.

Picken, Mary Brooks., and Mary Brooks. Picken. A dictionary of costume and fashion: historic and modern; with over 950 illustrations. Mineola, NY: Dover Publications, 1999. Print. 
Pride and Prejudice. By Susan Duncan and Siobhan Redmond. Prod. Lucille McLaughlin. Dir. Alistair Scott. British Broadcasting Corporation (BBC), 1996.

Tortora, Phyllis G., Sara B. Marcketti, and Phyllis G. Tortora. Survey of historic costume: student study guide. New York: Fairchild, 2015. Print

Weill, Kurt, Lotte Lenya, Bertolt Brecht, Desmond Ivo. Vesey, and Eric Bentley. The threepenny opera. New York: Grove Press, 1982. Print.

"Who is Bertolt Brecht? Everything You Need to Know." Childhood, Life Achievements \& Timeline. N.p., n.d. Web. 19 Mar. 2017.

Williams, Tennessee. A Streetcar Named Desire; with an introduction by Arthur Miller. Place of publication not identified: New Directions, 2004. Print.

Wilson, Landford. The Rimers of Eldritch. 440 park ave. New York, NY 10016:

Dramatists Play Service INC., n.d. Print. 